\title{
CHRONOLOGICAL EVOLUTION OF THE URASHIMA TARŌ STORY AND ITS INTERPRETATION
}

\author{
By \\ Yoshihiko Holmes
}

\begin{abstract}
A thesis
submitted to the Victoria University of Wellington in fulfilment of the requirements for the degree of Master of Arts in Japanese
\end{abstract}

Victoria University of Wellington 


\section{TABLE OF CONTENTS}

Abstract

\section{PART ONE}

General Introduction

CHAPTER 1: Introduction

CHAPTER 2: Overview of the Literature

4

\section{PART TWO:}

Analysis, from the Asuka Period (593-710 CE) to the Heian Period (794-1185 CE).

CHAPTER 3: Asuka, Hakuhō and Nara Periods (710-784 CE)

\section{PART THREE:}

Analysis, from the Muromachi Period (1392-1573 CE) to the Shōwa Period (1926-1989

$\mathrm{CE})$.

CHAPTER 5: Muromachi Period (1392-1573 CE)

PART FOUR:

Conclusions 
References:

Bibliographies:

168 


\begin{abstract}
The present thesis examines the evolution of the Urashima story. In modern Japan traditional Japanese tales have been presented in the form of illustrated books for young children. It is generally regarded that these tales contain common motifs or moral lessons; however, the Urashima story, one of the most well-known stories in Japan, seems to differ greatly from other folktales.

Scholars believe that the Urashima story was a popular pre-written orality-based story among the coastal dwelling ama group of people in ancient times in Japan. The introduction of a writing system from China made it possible to record the Urashima story as a written text.
\end{abstract}

However, the first recorded version of the Urashima story, putatively in the late seventh century, was quite different from later versions in terms of plot, purpose and the characters. The ideology of immortality, suggesting Chinese Daoist origins, was the main purpose of the story for several centuries, overlain by Buddhist influences.

The present study finds that the major turning point in the tale from an oralitybased story to a literary text was in Otogizoshi in the Muromachi Period $\left(14^{\text {th }}-16^{\text {th }}\right.$ centuries), when people still seemed to be attuned to orality-based puns and the satirical and witty use of word plays through the exchange of songs.

During the ensuing Edo Period, the Urashima story was transformed into a book for reading material. It changed at this time due to social developments, such as the widespread manufacture of paper and the technological development of woodblock printing. A shift in its themes and motifs such as immortality to Buddhist and social moral lessons occurred along with changing the cultural values of society, increase in literacy, and the appearance of new genres of literature and their writers in the Edo Period.

The establishment of the formal compulsory education system in the Meiji Period, accompanied by a shift in readership from educated adults to school children, further changed the story and its purpose, and resulted in the standardisation of the Urashima Tarō story that is well known today. Much of the well-known content of the current Urashima story in modern day Japan has appeared only within the last 150 years. 
Therefore, from this thesis it is apparent that the Urashima story evolved as a reflection of Japanese society's changing views. In short, this study identifies and analyses significant changes to the original recorded story that have appeared over the past fourteen hundred years. 


\section{PART ONE}

\section{General Introduction}

\section{CHAPTER 1: Introduction}

The Urashima story is one of the most well-known stories in Japan, and it is generally regarded as a folktale for young children that in modern times has been presented in the form of an illustrated book that tells a traditional Japanese tale.

Briefly summarised, Urashima Tarō rescues a turtle on the beach and is then invited by the turtle to a palace under the sea in return for his kindness. Urashima Tarō enjoys hospitality at the Sea Palace and spends a few days there, but finally he wishes to go home, so the Princess gives him a mysterious treasure box which he is told not to open. When Urashima Tarō returns to the real world, he cannot find his family because a few hundred years have elapsed. The curious Urashima Tarō opens the treasure box and white smoke puffs out of it, transforming him into an old man.

These folktales or mythological types of stories usually have a motif or theme such as "good or bad", "greedy or modest", "generous or mean" or "success or failure". In short, many such stories that include or contain these types of motifs offer some moral or ethical lessons. It is unclear what moral the Urashima Tarō story really conveys to us. This story's ending is quite different from many other popular folktales in Japan, and differs somewhat from version to version. In order to analyse and clarify this, the present research will focus on several aspects of the story. For example, it is not clear whether Urashima Tarō is a child or an adult, what the significance is of the big turtle which Urashima rescues, and what the significance is of Urashima Tarō spending time under the ocean carousing with a group of women. Also why is Urashima Tarō given a mysterious treasure chest type of box which he is told not to open, and when he does, why does the box produce smoke and turn him into an old man? Having saved the turtle, does he deserve to become an old man? The ending of this story is quite abrupt and is not the typical happy ending of myths or folktales in Japan or other parts of the world. What is the significance of this?

Therefore, the aims of this thesis are to identify (1) how the Urashima story evolved from the pre-written-text times to modern times, (2) why the story changed, 
and what influenced the authors to change the storyline from previous versions, (3) how the Urashima Tarō story has been passed on from generation to generation in Japan and (4) how the Japanese people have chronologically interpreted and understood the story.

It is widely believed among Japanese scholars that the history of the Urashima story traces back to the Nara Period $(710-784 \mathrm{CE})^{1}$ or before. In addition, the Urashima story is believed to have been an oral story before it was recorded and that it might relate to the ancient ama group of coastal-dwelling people. The Urashima stories contain similar motifs or threads, and characters from an early period of time.

However, what contemporary Japanese people know about the story in general differs from earlier versions. This could be a geographical issue as there are a variety of versions existing all over Japan. However, even in the same location, such as in Tokyo, are quite different from previous versions, particularly in regards to the thread, motifs and characters; and embellishment or additions by the author may be a factor in this.

Methodology for this thesis will be firstly to provide a recent scholarly commentary in the literature reviewed. This will be followed by a brief historical overview, comparison of versions and analysis of motifs, characters and ideologies. Diagrams of the tale's development will be presented in order to clarify how the Urashima story has changed over time. Finally, a translation of noteworthy versions from various historical periods will be provided in Appendix 1, in order that readers of English may follow the developments.

The present study addresses fifteen versions of the Urashima story, classifying them into twenty-eight categories in Table 1, in order to analyse their lineages, their chronological relationships and development, and thereby seek an interpretation through comparison and contrast among them (see overall conclusion). These categories are derived from the main characters in the story, and identify the key elements of the story in each version, to highlight the clear and significant differences among the Urashima versions. In addition, historical background of each Japanese literary period will be briefly outlined to further explain aspects of Japanese literary development and cultural growth which could have influenced the development of the story.

However, issues were identified whereby the recorded versions of the Urashima text do not necessarily match the time of publication, highlighting a time gap between

${ }^{1}$ Shimmura, 1993, 1930. 
the completion time of some recorded texts and their publication. To avoid this problematic gap, the putative timing of the recorded text of the Urashima story will be focused on in this study rather than the compilation of the book or of publication time of the same text, so that the evolution of the Urashima story can be analysed chronologically purely on the basis of the timing of the recorded text. By this means, identification of lineage development from the previous version, how the Urashima story developed, and later embellishments will be considered.

Based on the Japanese periodization system of the Urashima story lineage development, the present study is divided into five, Part One: General Introduction, Part Two: Analysis, from the Asuka Period (593-710 CE)² to the Heian Period (794-1185 CE), ${ }^{3}$ Part Three is from the Muromachi Period (1392-1573 CE) ${ }^{4}$ to the Shōwa Period (1926-1989 CE). ${ }^{5}$ And Part Four is conclusion including Translation in Appendix 1.

Part Two analysis is relatively complicated due to the various time discrepancies, and also the appearance of the same story names, so Diagram 1 is provided in order to understand the lineage development more clearly and in order to follow the development of influential texts.

Clarifying the complicated development of Part Two allows us to understand how the Urashima story developed in early historical times, and how this development influenced its further development in Part Three. Therefore, the present study provides historical overviews, analysis of the sources, comparisons of motifs and their development in Diagram 2, and Table 1 for key characters. This evidence will identify the development phases and influential elements, and also assists understanding broadly how the modern standardised Urashima story evolved in general.

\footnotetext{
2 Daijirin, “Asuka Jidai”, kotobank, 2006. <http://kotobank.jp/word/\%E9\%A3\%9B\%E9\%B3\%A5\%E6\%99\%82\%E4\%BB\%A3?dic=daijirin\& oid=DJR_asuka_-010-_zidai_-01Tokyo:>. Accessed on 10 ${ }^{\text {th }}$ Dec, 2013.

${ }^{3}$ Shimmura, 1993, 2296.

${ }^{4}$ Shimmura, 1993, 2506.

${ }^{5}$ Shimmura, 1993, 1289.
} 


\section{CHAPTER 2: Overview of the literature}

Recent scholarship centred on the Urashima Tarō myth is reviewed here briefly. Focus will be on commentaries by Sakaguchi Tamotsu (阪口保 1897- ), Shigematsu Akihisa (重松明久 1919-1989), Miura Sukeyuki (三浦佑之 1946- ) and Mifune Takayuki (三舟隆之 1959- ) as the main recent scholarly exponents. ${ }^{6}$

The first significant post-war commentary on the Urashima story was by Sakaguchi (1955). In this he states that the earliest Urashima story appears in Manyōshū (万葉集 Collection of Ten Thousand of Leaves, 350-759 CE), ${ }^{7}$ which he believes is a myth. ${ }^{8}$ Sakaguchi refers to the earlier Urashima story that putatively existed in ancient times before it was recorded in Tango no Kuni Fudoki Itsubun (丹後 国風土記逸文 Chronicle of the Topography of Tango Region, post $713 \mathrm{CE}),{ }^{9}$ which is also mentioned in Nihonshoki (日本書紀 The Chronicles of Japan, 720 CE), is hypothetically called "Old Urashimako Den”, as recorded by Iyobe no Umakai no Muraji (伊預部馬養連 date unknown), but it is not possible to identify the specific details of the story. And he notes that the Urashima story is chronologically recorded as also appearing in Fusōryakki (扶桑略記 Abbreviated History of Japan, ${ }^{10}$ after 1094 CE), Gunshoruijū (群書類従 Collection of Old Japanese Books, 1819 CE), and Kojidan (古事談 Discussions about Ancient Matters, ${ }^{11}$ 1212-1215 CE). ${ }^{12}$

Sakaguchi mentions that Otogizōshi (御伽草子 The Fairy Tale Book, 1716-1736 CE) in the Muromachi Period (1392-1573 CE) changed the interpretation of the Urashima story into literature for common people and a more 'Japanese' version, and he also introduced the different versions and famous authors from the Edo Period (1603$1867 \mathrm{CE})^{13}$ to the recent post-war period. ${ }^{14}$ The methodology Sakaguchi employs are to list and explain the various versions of the Urashima stories from each period; however

\footnotetext{
${ }^{6}$ Names of Japanese authors will be in Japanese order of family name followed by personal name.

${ }^{7}$ Hino, 2012, 1062.

${ }^{8}$ Sakaguchi, 1955, 1 and 6-7.

${ }^{9}$ Hino, 2012, 1062.

${ }^{10}$ Hino, 2012, 1058.

${ }^{11}$ Hino, 2012, 1065.

${ }^{12}$ Sakaguchi, 1955, 32 and 65.

${ }^{13}$ Shimmura, 1993, 285.

${ }^{14}$ Sakaguchi, 1955, 76, 78, 90-93, 97, 111, 114 and 151.
} 
he does not explain in detail how the Urashima story as folklore became so popular among young children in Japan, and he did not introduce Matsutani Miyoko's Urashima Tarō (浦島太郎 The fisherman under the sea, 1967) version, which postdates publication of his book.

Shigematsu (1981) approaches the Urashima story as a well-known oralitybased story first, folklore that was recorded through the Nara Period to the present. His commentary accompanies his translation into modern Japanese of "Urashimako Den (浦 島子伝 A biography of Ura Shimako)" in Kojidan (1212-1215 CE). ${ }^{15}$ The methodology he employs is linguistic analysis of vocabulary usage, discussion of the character's historical existence, and analysis of the narrative, which is very theoretical but quite a different approach to that of Sakaguchi, Miura and Mifune. ${ }^{16}$

Shigematsu examines the putative authors, and their historical achievement and academic knowledge. He finds that these putative authors might not be the authors at all, but have merely embellished or added some story lines from a previous version, and recorded their names on the work. ${ }^{17}$ Shigematsu proposes a logical explanation for this, and conducts radical analysis that has not been undertaken by other modern scholars. He researches thoroughly in an attempt to identify the original parts of the story. Shigematsu notes that the orality-based Urashima story developed along with cultural growth, but he does not focus much on how the story spread to become well-known, such as through increasing literacy levels, printing techniques, or the increasing availability of books.

By using the above methodology, Shigematsu finds that there must be a time gap between when the Urashima story texts were first recorded and their compilation, so that some of the stories are believed to be appeared later, while the text itself was recorded much earlier. ${ }^{18}$ For example, Kojidan is believed to have been published in 1212-1215, but "Urashimako Den" which appears in Kojidan was clearly recorded much earlier than the Nara Period, and it could even be the very earliest recorded Urashima story, dating from the Asuka Period. ${ }^{19}$ Shigematsu's conclusions are based

\footnotetext{
${ }^{15}$ Shigematsu, 1981, 31-39.

${ }^{16}$ Shigematsu, 1981, 130, and 143-146.

${ }^{17}$ Shigematsu, 1981, 127-131 and 137-138.

18 Shigematsu, 131-134, and 137.

${ }^{19}$ Shigematsu, 1981, 137.
} 
on his analyses of the Urashima story from the viewpoint of vocabulary usage and the expression of words. He also tries to distinguish the lineage development of the Urashima story, how each version is related to others, and the reason why some stories do not have the same thread or storyline or description compared to other versions. ${ }^{20}$ This approach was very different from other scholars, ${ }^{21}$ as the 'orthodox' chronology assumed by most scholars is based on the publication time and year of the text in which the tale appears, without paying much attention to the age of the text's content.

More recently, the Urashima Tarō myths have been considered by Miura (1989 and 2006). In his 1989 monograph, he focuses mainly on the relationship between Meiji Period versions and more modern versions of the tale. ${ }^{22}$ Miura's monograph is followed by a chapter on Urashimako in his 2006 monograph, Nihon Kodai Bungaku Nyūmon (日本古代文学入門 Introduction to Ancient Japanese Literature). ${ }^{23}$

Miura's book in 1989 examines the Urashima Tarō story and its origins, roots, interpretation, different versions, and evaluation. Miura explains the modern Urashima Tarō story in general and looks for the roots of this story in his first chapter. He argues that the thread of the Urashima Tarō story in modern understanding became firmly fixed through written literature, and speculates and that it is unlikely to be modified much in future. This fixed material is the version of "Urashima Tarō" as it appears in the Ministry of Education Designated textbook (国定教科書 Kokutei Kyōkasho) of the Meiji Period (1868-1912). ${ }^{24}$

Miura demonstrates that this Urashima Tarō story and the popularised modern (post war) Urashima story are so much alike that they are almost identical, such that the modern Urashima Tarō story is clearly based on the story from this textbook. ${ }^{25}$ Miura solves the question of who the author of this Urashima Tarō version was, and identifies him as Iwaya Sazanami (嚴谷小波 1870-1933). He was a leading author of children's literature, and compiled Nippon Mukashibanashi (日本昔噺 Folktales from Japan, 1896), which contained humour and entertainment aspects typical of Sharebon (酒落

\footnotetext{
${ }^{20}$ Shigematsu, 1981, 130-131, 133-134, 136.

${ }^{21}$ Sakaguchi, Miura and Mifune.

${ }^{22}$ Miura, 1989, 20-52.

${ }^{23}$ Miura, 2006, 50-71.

${ }^{24}$ See Chapter 7.

${ }^{25}$ Miura, 1989, 21.
} 
本), a genre which was popular in the Edo Period (1603-1867 CE). ${ }^{26}$ As a result, the modern Urashima story prototype is based on Iwaya's version.

Nihonshoki (completed $720 \mathrm{CE}$ ) is an official chronicle which contains one of the earliest versions of the Urashima story, and in chapter two, Miura examines its role and authenticity without fully tracing links between the earliest written versions and those of the present day. He argues that the brief Urashima story in this document must have existed before Nihonshoki was compiled, since the last line, 語在別巻 ( go zai bekkan), meaning "it is in another volume", indicates that the Nihonshoki version was based on that. However, Miura doubts that an official chronicle would rely on a story from other works which is not related to Nihonshoki at all, neither Manyōshū nor Tango no Kuni Fudoki Itsubun. That is Miura's view and his interpretation of 語在別巻. In other words, he admits that the Urashima story, which he believes is the (now lost) version that Iyobe no Umakai no Muraji recorded, must be older than Nihonshoki. ${ }^{27}$

A god changing its form into an animal is a common motif in Japanese mythology, but a god changing its figure into a turtle and approaching a human is quite rare. That concept of the turtle being a bright five-coloured one is connected to Buddhism and Daoism ${ }^{28}$ in China. From this, Miura deduces that the Urashima version in Tango no Kuni Fudoki Itsubun was really intended as "reading material" of what was probably a popular tale, for intellectuals in the Nara central government, as it includes very current contemporaneous thought and a philosophical subject. ${ }^{29}$

Furthermore, Miura points out several unverifiable points such as Urashimako's ancestors being a powerful local family called Kusakabe, but there is no other evidence to corroborate their relationship, and it is irrelevant to the story overall. Their family line or genealogy seems to be superfluous because they do not alter the story lineor motifs. ${ }^{30}$

Also, he regards the Tango no Kuni Fudoki Itsubun version as essentially "erotic". Miura's emphasis on the erotic aspects of the tale is idiosyncratic. Miura

\footnotetext{
${ }^{26}$ See Chapter 7.

${ }^{27}$ Miura, 1989, 60-61; 2006, 51-55.

${ }^{28}$ On Daoism, see Ooms, 2009, Ch6, 132-153.

${ }^{29}$ Miura, 1989, 79-80.

${ }^{30}$ Miura, 1989, 77-78.
} 
possibly exaggerates and focuses on this aspect for entertainment value. Because of the pornographic aspect, it had the potential to be popular for only a certain demographic group of people, probably men who were very highly educated aristocrats, bureaucrats or politicians, and those wealthy enough to have access to manuscripts, but generally speaking the Urashima story has not been recognised as a pornographic work. The present study finds, rather, that it is inappropriate to emphasise this. Contrary to Miura's emphasis, the Urashima plot overall is not focused on sexual conduct. ${ }^{31}$ While Miura's approach and interpretation of the Urashima story is noteworthy, I regard these erotic and sexual versions of Urashima as only one small part of the Urashima history during a particular period in Japanese literary history.

Miura concludes that the Urashima story in Tango no Kuni Fudoki Itsubun is fiction, while in Nihonshoki, an official chronicle, it is written as though it were history. It is unclear how people recognised and distinguished fiction from non-fictional stories at that time. ${ }^{32}$

Miura describes that as time went by, the kana version of the Urashimako story was widely accepted by non-classical-Chinese-style readers; he also notes that the article “Asamogawa myōjin (あさも川明神 Asamo river Gods)” in Mumyōshō (無名抄 Nameless Notes) written by Kamo no Chōmei (鴨長明 1155?-1216) in 1221-1222 CE is a noteworthy work in order to certify the existence of Urashimako enshrined as a god. ${ }^{33}$ He adds that Urashima Tarō in Otogizōshi, the oldest existing work of which was written in the late fifteenth century, is a picture book. This book is centred on the colourful pictures, but the writing itself is not in detail. ${ }^{34}$

In the final chapter, Miura concludes that the Urashima story developed from the Classical Chinese style of literature, was turned into kana literature which was described more freely and imaginatively in the Muromachi through to the Edo Period, and then finally became the contemporary Japanese folklore versions from the Meiji through to post war periods. ${ }^{35}$

\footnotetext{
${ }^{31}$ Miura, 1989, 85-87; 2006, 55-58.

${ }^{32}$ Miura, 1989, 107-108; 2006, 52-53.

${ }^{33}$ Miura, 1989, 163.

${ }^{34}$ See Chapter 5.

${ }^{35}$ Miura, 1989, 198; 2006, 69-70.
} 
Finally, Mifune (2009) starts by explaining and clarifying the modern version and the popular types of the Urashima Tarō story in the first chapter of his book. Mifune introduces variations of the story, such as Urashima Tarō turning into an old man after opening the treasure box, or Urashima Tarō turning into a crane after opening the box and the turtle princess coming back again to see him. ${ }^{36}$ Mifune does not debate these variations in the story or critique them in much depth, but he argues that there is a basic thread to them which varies depending on the geographical area, and that usually some essence of the local culture and imaginative story have been added and then assimilated as a local Urashima Tarō story. ${ }^{37}$

Mifune's aim in this book is to trace "the history of the Urashima Tarō tale", so that the Urashima story is followed in chronological order. Mifune does not discuss it much compared to the aforementioned scholars, and he only lists common versions of the Urashima story, though the age of texts is not thoroughly examined. In addition, it seems that Mifune only follows the chronological order of the publication of each version, and he merely introduces and explains the versions of the Urashima story. He introduces similar stories in China and Korea, which could be the original source of the Urashima story, but his conclusion is vague, and he ends with the statement that more research is required. In short, this book uncritically follows the chronological order which people in general believe in Japan currently.

However, Mifune explains the Urashima story by means of a different approach compared to other scholars such as Shigematsu and Miura. He argues the main character of the Urashima story, Urashimako, existed as an ancestor of the Kusakabe family, a view which completely opposes Miura's argument. ${ }^{38}$

Mifune regards Tango no Kuni Fudoki Itsubun version as one of the generalised versions of the Urashima story. He provides a map of the Tango region, confirms the village name of Hioki in Miyazu city, Kyoto Prefecture, and focuses on the ancient archaeological sites in the area, which relate to the local prosperity at that time. ${ }^{39}$ Also Mifune concludes that the prototype of this Urashima story may be ancestral folklore of the Kusakabe family, a local ruling family ( $g \bar{o} z o k u$ 豪族) assumed to have originally

\footnotetext{
${ }^{36}$ Mifune, 2009, 3-13.

${ }^{37}$ Mifune, 2009, 13-14.

${ }^{38}$ Mifune, 2009, 27.

${ }^{39}$ Mifune, 2009, 27.
} 
migrated from the Asian continent. This symbolises their power and political standing, and therefore, the Urashima story in this version became standardised in the Tango region. ${ }^{40}$

Mifune regards the romantic description in “Zoku Urashimako Denki (続浦島子 伝記 A biography of Ura Shimako, second series)" in Gunshoruijū as not erotic because the description of romance or love in the stories during the Heian Period was not unusual. If there is a description of sexual conduct, it was mentioned from a Taoist medical view and there is no intention to emphasise the erotic; rather the Urashima story is the literature of the ideology of immortality at that time. ${ }^{41}$

${ }^{40}$ Mifune, 2009, 31-37.

${ }^{41}$ Mifune, 2009, 79-80. 


\title{
PART TWO
}

\author{
Analysis, from the Asuka Perido (593-710 CE) $)^{42}$ to the Heian Period (794-1185 \\ CE). ${ }^{43}$
}

\section{CHAPTER 3: Asuka, Hakuhō and Nara Period (710-784 CE)}

\section{Historical overview: Asuka Period (593-710 CE) and Hakuhō Period (645-710 \\ $\mathrm{CE})^{44}$}

Shimmura (1993) explains that the Hakuhō Period is from the second half of the seventh century to the early eighth century, a historical period in Japan that was important to Japanese cultural history, particularly in regard to art history of arts including the commencement of a literary culture. The authority of Emperors was also established, especially after the Jinshin Rebellion (壬申の乱 Jinshin no ran) ${ }^{45}$ in 672 $\mathrm{CE}$, and the Hakuhō Period created a powerful new culture such as the establishment of a nationwide legal code, the beginning of the compilation of Nihonshoki (720 CE) and Kojiki (古事記 Record of Ancient Matters, 712 CE), the appearance of Manyōshū poets, and the flourishing of Buddhist art. ${ }^{46}$ The Asuka Period, from Shōtoku Taishi’s serving as Regent in $593 \mathrm{CE}$ to the relocation of the capital of Heijo in $710 \mathrm{CE}$, is an important historical period, particularly concerning state-formation in Japan. ${ }^{47}$

${ }^{42}$ Daijirin, “Asuka Jidai”, Kotobank, 2006. <http://kotobank.jp/word/\%E9\%A3\%9B\%E9\%B3\%A5\%E6\%99\%82\%E4\%BB\%A3?dic=daijirin\& oid=DJR_asuka_-010-_zidai_-01Tokyo:>. Accessed on 10 $0^{\text {th }}$ Dec, 2013.

${ }^{43}$ Shimmura, 1993, 2296.

${ }^{44}$ Daijirin, "Hakuhou Jidai", Kotobank, 2006. <http://kotobank.jp/word/\%E7\%99\%BD\%E9\%B3\%B3\%E6\%99\%82\%E4\%BB\%A3?dic=daijirin\& oid=DJR_Hakuhō_-020-_zidai_-01>. Accessed on 13 ${ }^{\text {th }}$ Dec, 2013.

45 Jinshin-no-ran, Civil War of 672 CE, a younger brother of Prince Ōama (Emperor Tenji) revolted to the elder brother of Prince Ōtomo (Emperor Kōbun) at the central goverment. Shimmura, 1993, 1334.

${ }^{46}$ Shimmura, 1993, 2049.

${ }^{47}$ Daijirin, “Asuka Jidai”, Kotobank, 2006. <http://kotobank.jp/word/\%E9\%A3\%9B\%E9\%B3\%A5\%E6\%99\%82\%E4\%BB\%A3?dic=daijirin\& oid=DJR_asuka_-010-_zidai_-01Tokyo:>. Accessed on 10 $0^{\text {th }}$ Dec, 2013. 


\section{Source No.1: “Urashimako Den” (593-710?), Kojidan (1212-1215 CE)}

Source: Shigematsu, Akihisa (ed.). "Urashimako Den" [Kojidan] Dai Isshū

(Shintei Zōho Kokushi Taikei). Tokyo: Gendai Shichō Shinsha, 2006, pp. 29-32.

Appendix 1: Number 1, pp. 112-114.

Kojidan is a narrative anthology of sixth volumes compiled by Minamoto no Akikane (源顕兼 1160?-1215?) between 1212-1215 CE in the Kamakura Period (1185$1333 \mathrm{CE})^{48}$, containing four hundred and sixty-two narrative stories, many of which are about the Palace, aristocracy, and temple monks. It also contains many extracts cited from previous works, and is a very important product in terms of narrative folklore. ${ }^{49}$ The Kamakura age in Japanese history stands midway between the centralized rule of the Nara and Heian times and the localism of the Muromachi era. This transition focuses on the establishment of warrior government (bakufu 幕府) in the 1180s, the nature of the new civil-military diarchy, and the activities of the thirteenth century's most important local officials, the shugo $(\text { 守護 })^{50}$ and jito $(\text { 地頭 })^{51}$

Scholars can deduce the age of the text and discrepancies between the year of its recording and appearance in circulation by the vocabulary used. Based on this, the text of "Urashimako Den" is thought to be a much older version than its date of appearance, and judging from its vocabulary, it could be even older than the Nara Period (710-784 CE). ${ }^{52}$ The Urashima story it contains could be one of the products of the new culture in the Hakuhō Period, and the story titled "Urashimako Den" in Kojidan, which is believed to have been compiled in the Kamakura Period (1185-1333 CE), could in fact

\footnotetext{
48 Shimmura, 1993, 527.

${ }^{49}$ Sekai Daihyakka Jiten, “Kojidan”, Kotobank, 2006. <http://kotobank.jp/word/\%E5\%8F\%A4\%E4\%BA\%8B\%E8\%AB\%87?dic=daijirin\&oid=DJR_kozi dann_-010>. See also Daijirin, "Kojidan", Kotobank, 2006. <http://kotobank.jp/word/\%E5\%8F\%A4\%E4\%BA\%8B\%E8\%AB\%87?dic=sekaidaihyakka\&oid=00 169819>. Accessed on $16^{\text {th }}$ Dec, 2013.

${ }^{50}$ Shugo is a hereditary military constable. Encyclopædia Britannica online, "shugo”, 2013. <http://www.britannica.com/EBchecked/topic/304067/jito>. Accessed on 16 ${ }^{\text {th }}$ Jan, 2014.

${ }^{51} \mathrm{Jito}$ is a land steward appointed by the central military government, or shogunate. Encyclopædia Britannica online, "jitōo", 2013. <http://www.britannica.com/EBchecked/topic/304067/jito>. Accessed on $16^{\text {th }}$ Jan, 2014. See also Mass. 1976, 3.

${ }^{52}$ Shigematsu, 2006, 137.
} 
have originated much earlier, in the Hakuhō Period. For example, noteworthy vocabulary in “Urashimako Den” in Kojidan includes Nani (南威) and Seishi (西施), ${ }^{53}$ and also “tenkansui" (天漢: tenkan, means the Milky Way and 水: sui, means water). ${ }^{54}$ Similarly used vocabulary such as amanogawa (天河 “the Milky Way”) appears first in Bunkashūreishū (文華秀麗集 The second Imperial Chinese poem collection) in 818 $\mathrm{CE}$, and tenkan can be found in Ryōunshū (凌雲集 A collection from above the clouds) in 814 CE. Both amanogawa and tenkan were also often used in Manyōsh $\bar{u} .{ }^{55}$ Therefore, judging from this vocabulary usage, "Urashimako Den" in Kojidan may putatively date back to some time between the Hakuhō Period (645-710 CE) ${ }^{56}$ and the early Heian period (794-1185 CE). ${ }^{57}$

Shigematsu (2006) continues that "Urashimako Den" in Kojidan is speculated to be the original source of several versions of "Urashimako Den" and "Zoku Urashimako Denki," although there is not enough evidence to decide whether "Urashimako Den" in Kojidan is the oldest extant text or not. ${ }^{58}$ However, another noteworthy vocabulary usage in the Kojidan version of "Urashimako Den" may identify the oldest extant version, and this is kintan (金丹 “golden elixir”). Because of its toxicity, this has rarely been used as a medicine of immortality since the early Heian Period (794-1185 CE) so Urashimako Den in Kojidan was likely not written after the Heian Period. ${ }^{59}$ The existence of the personal names "Nani" and "Seishi", a term for the Milky Way, "tenkan (sui)", and the elixir "kintan" does not in itself prove that the Kojidan text predates the

\footnotetext{
${ }^{53}$ Nani (南威) is a beautiful woman from Jin (晋), a major state in China during the middle part of the Zhou Dynasty and during the Spring and Autumn Period (BC770 - 403), and Seishi (西施) is a beautiful woman from Yue (越), a state in China which existed during the Spring and Autumn Period. Shigematsu, 2006, 33-34.

${ }^{54}$ Shigematsu, 2006, 34.

${ }^{55}$ Shigematsu, 2006, 136-137. See also Sekai Daihyakka Jiten, “Bunkashūreishū”, Kotobank, 2006, <http://kotobank.jp/word/\%E6\%96\%87\%E8\%8F\%AF\%E7\%A7\%80\%E9\%BA\%97\%E9\%9B\%86? dic $=$ sekaidaihyakka\&oid=00298825>, Accessed on $16^{\text {th }}$ Dec, 2013, and Daijirin, "Ryōunshū", Kotobank, 2006. <http://kotobank.jp/word/\%E5\%87\%8C\%E9\%9B\%B2\%E9\%9B\%86?dic=daijirin\&oid=DJR_ryouu nnsyuu_-010>. Accessed on $16^{\text {th }}$ Dec, 2013.

${ }^{56}$ Shigematsu, 2006, 136-137.

${ }^{57}$ Shimmura, 1993, 2296.

${ }^{58}$ Shigematsu, 2006. 137.

${ }^{59}$ Shimmura, 1993, 2296.
} 
the three Nara-period texts, but Shigematsu's view deserves attention, and his argument is very persuasive. ${ }^{60}$

It is also noteworthy that cinnabar, a reddish mineral (丹 $\mathrm{J}$ : tan, mercury sulphide) was regarded as a longevity medicine which conferred immortality: symbolically, it is linked with the colour red, is a basic substance of Taoist alchemy, and a component ingredient in many an elixir which was supposed to confer longevity but which all too often cut short the lives of those who put too much trust in such things. ${ }^{61}$ Therefore, the Urashima story in the Kojidan version may indicate that the people at that time were curious about immortality, and so the main character was described as taking a golden elixir which was not known yet as a dangerous product in the Hakuhō Period (645-710 CE). As a result, the main character turned into an old man instead of living longer or forever, because of imbibing cinnabar. The most important message for the people in the Hakuhō period may have been that longevity and immortality were still a dream. It may also have been a moral lesson of the fragility of life, that cinnabar in fact shortens human life. Therefore, "Urashimako Den" appears to be even older than the Manyōsh $\bar{u}$ version, making it the oldest extant version among the Urashima stories, so for the purposes of the present research this "Urashimako Den" in Kojidan is the first text. ${ }^{62}$ It certainly seems to be the earliest known version of the Urashima story.

There is a hypothesis that Iyobe no Umakai no Muraji, a former provincial governor, may putatively be the author of the text of "Urashimako Den" in Kojidan. There are several reasons to suggest that Iyobe no Umakai no Muraji might have been the first to record the written Urashima story, presumably in the Hakuhō Period. According to Kaifūsō (懐風藻 Fond Recollections of Poetry, $751 \mathrm{CE}$ ), ${ }^{63}$ Iyobe no Umakai no Muraji died at the age of forty-five, and according to Shoku Nihongi (続日 本紀 Chronicle of Japan Continued, 797 CE) ${ }^{64}$ Umakai’s adopted son was given some

${ }^{60}$ This kind of unorthodox view of Japanese literature is expressed by John Bentley in The authenticity of Sendai kuji hongi: a new examination of texts, with a translation and commentary, 2006.

${ }^{61}$ Morohashi, 1 1971, vol.1, 321. See also Eberhard, 1986, 66.

${ }^{62}$ Yan, 1995, 33-35.

${ }^{63}$ Kaifüsō (751CE), an anthology of poetry in Chinese composed by members of the court. Encyclopædia Britannica online, "Kaifūsōo", 2013. <http://www.britannica.com/EBchecked/topic/309757/Kaifuso>. Accessed on 16 ${ }^{\text {th }}$ Dec, 2013.

${ }^{64}$ Shoku Nihongi is a chronological historical book from 697 - 791CE in early Heian Period. Daijirin, "Shoku Nihongi", Kotobank, 2006. <http://kotobank.jp/word/\%E7\%B6\%9A\%E6\%97\%A5\%E6\%9C\%AC\%E7\%B4\%80?dic=daijirin\& oid=DJR_syokunihonngi_-010>. Accessed on $16^{\text {th }}$ Dec, 2013. 
property in Taihō Year 3 (703 CE) so it may be assumed that Umakai was deceased by Taihō Year 2 (702 CE). If so, it may be deduced that he was born in or around 657 CE. ${ }^{65}$ There is no doubt that Umakai lived in the Hakuho Period (645-710 CE) and he might well have been the person to record "Urashimako Den" while he was in the Tamba region as provincial governor. Miura (1989) also argues that it is highly likely that the Urashima story written by Iyobe no Umakai no Muraji was already in existence by the end of the seventh century, because of the year of his death. Thus there is no doubt that the written version of the Urashima story existed by then. ${ }^{66}$

Furthermore, the Tango no Kuni Fudoki Itsubun version (post $713 \mathrm{CE}$ ) contains the following sentences, "The following story is consistent with what Mr Iyobe no Umakai no Muraji, a former provincial governor, recorded" and "it does not differ from it". As a result, most modern scholarly commentators assume that the text in Tango no Kuni Fudoki Itsubun is substantially that recorded by Iyobe. However, the author/scribe of the Urashima story in Tango no Kuni Fudoki Itsubun is not recorded. The Urashima stories would likely have developed based on the original recorded story, which may be assumed to contain the oldest and also simplest moral lesson types of story rather than unnecessary literary embellishments. Therefore, putatively "Urashimako Den" in the Kojidan version contains more original source elements than Tango no Kuni Fudoki Itsubun, and it may be surmised that "Urashimako Den" in the Kojidan version was likely written by Iyobe no Umakai no Muraji or, rather, substantially based on his version.

"Urashimako Den" in Kojidan is very different from other Urashima stories. As can be seen from Appendix 1 (the translation of the Urashima stories, number 1 “Urashimako Den”, see pp. 112-114), "Urashimako Den” in Kojidan begins in 825 CE on Urashima's return from the time he spent with the maiden. However, this part appears to have been an embellishment by a later editor to place emphasis on Emperor Junwa, and the story needed to match the timeline, so "Urashimako Den" in Kojidan took on the style of describing Urashima's return first, followed by the rest of the story. ${ }^{67}$

\footnotetext{
${ }^{65}$ Shigematsu, 2006, 142-144.

${ }^{66}$ Miura, 1989, 105.

${ }^{67}$ Shigematsu, 2006, 33.
} 
As analysed above, the main body the story was probably not written in $825 \mathrm{CE}$ due to the specific vocabulary usage, the putative author being Iyobe no Umakai no Muraji. Shigematsu (2006) reconstructs the putative original version by deleting the embellishments added by the Kojidan editor, including deletion of the beginning of the story: "In the $2^{\text {nd }}$ year of the Tenchō period under the Emperor Junwa (825 CE)", and also the first part of the sentence commencing: "It said in the Urashimako Den..." In addition, the end of the first part of Urashimako Den, "However, it took three hundred years after he had left to return to his home. It is said that he looked like a child", is also a putative embellishment by the Kojidan editor. ${ }^{68}$

Kojidan is believed to have been compiled by Minamoto no Akikane between 1212 and $1215 \mathrm{CE}$, so by the time he completed it, he was able to access previous recorded versions of the Urashima story, particularly Tango no Kuni Fudoki Itsubun, Nihonshoki, and Manyōsh $\bar{u}$, or others unknown. It is possible therefore that he could have embellished some parts of "Urashimako Den", which are almost identical in description compared to other early versions of the Urashima stories. However, similarities and the lineage of the story, and also the influential recorded versions of the Urashima story will be examined later.

Therefore, for the aforementioned reasons above, including the vocabulary usage and the existence of the first recorded version of the Urashima story by the end of the seventh century, "Urashimako Den" in Kojidan will be examined here as putatively the first recorded version of the Urashima story.

\section{Historical overview: The Nara Period (710-784 CE) ${ }^{69}$}

As can be seen from Appendix 1, there are three early extant texts: Tango no Kuni Fudoki Itsubun (post 713 CE), Nihonshoki (720 CE) and Manyōshū (350-759 CE) in chronological order of compilation. Tango no Kuni Fudoki Itsubun contains a long and relatively detailed Urashima story, while Nihonshoki contains a merely short prose description, and the Manyōsh $\bar{u}$ version is a narrative song. However, the main purpose of each of these works is slightly different and they fulfil different roles. Although

\footnotetext{
${ }^{68}$ Shigematsu, 2006, 130.

${ }^{69}$ Shimmura, 1993, 1930.
} 
these Urashima stories have a common storyline, it is difficult to determine which of them is the earliest version. These texts were compiled at a similar period of time, first being recorded as written texts in the form of books or scrolls. It is noteworthy that Tango no Kuni Fudoki Itsubun, Nihonshoki and Manyōshū included the Urashima story, but the Urashima stories were not published as independent tales until much later, in the Edo Period (1603-1867) ${ }^{70}$ as one of the volumes of Otogizōshi. ${ }^{71}$ In other words, the original Urashima story was probably a very popular or well-known oral story at first, then, presumably, its first written text was recorded by Umakai in the Hakuhō Period (645-710 CE) — a version which was reproduced as "Urashimako Den" in Kojidan-, and after that, three of the above widely known Nara Period texts included reference to it. The recurrence of the Urashima story in these texts is perhaps indicative of their popularity; arguably, the Urashima story was recorded and compiled within a relatively short time during the Nara period, which means it was an important and valued story in the eighth century. That is likely one of the main reasons why all three texts, Tango no Kuni Fudoki Itsubun, Nihonshoki and Manyōshū, contain this story.

If the Urashima story was popular or a well-known story of orally transmitted folklore in the Nara period or prior, it was recorded in writing because of the introduction and development of Chinese characters in Japan. It is impossible to say exactly when, but written letters were starting to be used by the élite in Japanese society around the sixth century. Writing was used particularly for political and economic purposes. ${ }^{72}$ Sato also notes that the spoken language generally disappears and is not traceable, but the introduction of writing enabled the permanent recording of the spoken language which existed in Japan at that time. ${ }^{73}$ Japan, of course, had a spoken language and many spoken, oral stories such as mythologies, oral folklore, prayers and songs prior to the introduction of Chinese characters. Writing was learned by only a few élite people in society such as among the aristocracy. While there was no previous method to record oral stories in Japan before that time, this became possible during the Hakuhō and Nara periods, when centralised government under a unified polity necessitated the

\footnotetext{
${ }^{70}$ Shimmura, 1993, 285.

${ }^{71}$ Otogizōshi is the twenty three books published by Shibukawa Kiyouemon in Osaka in Kyōho (17161736). The Urashima story is one of these books called Urashima Tarō. Digital Daijisen, “Otogizōshi”, 2013. <http://kotobank.jp/word/\%E5\%BE\%A1\%E4\%BC\%BD\%E8\%8D\%89\%E5\%AD\%90?dic=daijisen \&oid $=02452500>$. Accessed on $16^{\text {th }}$ Jan, 2014.

72 Satō, 1995, 43-44.

${ }^{73}$ Satō, 1995, 10.
} 
recording of national histories. This meant that actually the Urashima story was recorded due to orders from government authorities in the Nara period. Thus, the important specific roles and purposes of Tango no Kuni Fudoki Itsubun, Nihonshoki and Manyōshū need to be clearly explained here, because they may explain same of the differences among these versions.

\section{Source No. 2: Putative completed date of the story (680-700?), Tango no Kuni Fudoki Itsubun (post 713) ${ }^{74}$}

Source: Uegaki, Setsuya (ed.). Fudoki. Tokyo: Shōgakukan, 2006, pp. 473-483.

Cited in: Urabe, Kanekata. "Urashimako", Shaku Nihongi, vol. 12, Maeda-ke bon [MS], late 13th century.

Appendix 1: Number 2, pp. 114-118.

Tango no Kuni Fudoki Itsubun is listed here as the first recorded version from the Nara Period, because of its putative compilation year and chronological order, making it the oldest extant record that contains the Urashima story in the Nara period.

It is also noteworthy that there is a sentence - in fact, four Chinese charactersat the end of the Urashima story in Nihonshoki: 語在別巻. 語 ( $g o$ ) means (1) talk, discuss, (2) language, word, (3) tale, story, narrative, legend, (4) term, phrase. ${ }^{75}$ 在 (zai) means (1) [exist in a specified place] be at (in), be situated in, (2) ask, (3) see, watch, observe, (4) reside (live) temporarily, stay. ${ }^{76}$ 別 (betsu) means (1) separate, part from, be separated, (2) sort, classified by, (3) another, different, distinct. ${ }^{77}$ 巻 (kan) means (1)

\footnotetext{
${ }^{74}$ Fudoki is a gebumi (解文), which means a document that was reported to the higher central government officials from the lower local government officials after the order from the central government in 713 CE. These days the documents are called Fudoki. There are five extant books of Fudoki: Harima, Hitachi, Izumo, Bungo and Hizen. Lost reported documents (original manuscripts) or loss of some parts of documents meant these did not survive as original documents, but some parts of the lost documents called Itsubun were able to be recovered from quotations and extracts in other books. Therefore, Tango no Kuni Fudoki Itsubun is one of these documents, and for this reason, this text is believed to have been compiled post $713 \mathrm{CE}$. Uegaki, 1997, 591 and 610.

${ }^{75}$ Morohashi, 1971, vol.10, 474. See also Halpern, 1990, 704.

${ }^{76}$ Morohashi, 1971, vol.3, 122. See also Halpern, 1990, 1362.

${ }^{77}$ Morohashi, 1971, vol.2, 235. See also Halpern, 1990, 516.
} 
turn, (2) roll up, roll, scroll, (3) volume, book. ${ }^{78}$ This sentence can therefore be translated as "There is another volume of this story in existence." The Urashima story in Nihonshoki (720 CE) thus indicates that there was a previous written version in existence when its version of the Urashima story was recorded. Therefore, we may infer from this that the Kojidan version was essentially the first (see above), the Tango no Kuni Fudoki Itsubun version was second and the Nihonshoki reference was recorded third, so Tango no Kuni Fudoki Itsubun is listed here as the second earliest extant chronological version.

In addition to this important sentence at the end of the Urashima story in Nihonshoki, the outline and the characters of the Urashima story in Kojidan, Tango no Kuni Fudoki Itsubun and Nihonshoki are more similar to each other than to the version in the broadly contemporaneous Manyōsh $\bar{u}$. The detailed similarity of this can be seen in Table 1 (see pp. 101-108), and examples are listed as follows: the place name of Yosa, capture of the turtle that turns into a woman, and the name of the place visited as Mt. Hōrai. Based on these reasons too, Tango no Kuni Fudoki Itsubun is listed here as the second recorded story.

Tango no Kuni Fudoki Itsubun is also the longest version of the Urashima story in the Nara period. It is written in a sophisticated literary style. Tango no Kuni Fudoki Itsubun is one fragment of the provincial report books called Fudoki, which were compiled due to an order from the Empress Gemmei in $713 \mathrm{CE}$, to describe five items: 1) the names of regions, districts, and villages, 2) the list of useful products of plants, animals and minerals, 3 ) the condition of the land, 4) the origins of the names of mountains, rivers and plains, and 5) the stories and folklore from ancient times. ${ }^{79}$ From the latter, it can be interpreted that Fudoki should contain old local stories and folklore, so for this reason it is unsurprising that the Urashima story was selected for inclusion in Tango no Kuni Fudoki Itsubun. It was probably a very old and well known folktale around the Tango region during the Nara period, at least around the year $713 \mathrm{CE}$ when the compilation was ordered, otherwise the Fudoki document from Tango Province would probably not have included it. It also implies that the Urashima story in this

\footnotetext{
${ }^{78}$ Morohashi, 1971, vol.2, 633. See also Halpern, 1990, 1208.

${ }^{79}$ Uegaki, 1997, 8.
} 
document must have had a close association with this place in particular, otherwise the Urashima story is likely to have appeared in a different volume of Fudoki.

In Tango no Kuni Fudoki Itsubun, the aforementioned Iyobe no Umakai no Muraji, a former provincial governor, is recorded as having written a previous longer version, and that the Tango no Kuni Fudoki Itsubun version "does not differ" from it. As a result, most modern scholarly commentators assume that the text in Tango no Kuni Fudoki Itsubun is substantially that recorded by Iyobe and, as we have already seen, it appears to have formed the basis of "Urashimako Den" in Kojidan.

According to Miura, Iyobe no Umakai no Muraji was a scholar who became an official in the government from $689 \mathrm{CE}$, and was one of the officials who edited the laws. ${ }^{80}$ He was able to access written documents such as laws, codes, and stories, and had a high level of literacy, so he could easily have been the first person to record the Urashima story, in an earlier document (now lost) referred to in Tango no Kuni Fudoki Itsubun. Alternatively Iyobe no Umakai no Muraji might have recorded the original version of the Urashima story as in Kojidan, then someone else recorded a dramatised Urashima story in Tango no Kuni Fudoki Itsubun from an oral version.

The author/scribe of the Urashima story in Tango no Kuni Fudoki Itsubun is not recorded, but it merely mentions Iyobe's name as the source of the story. However, his intelligence and literacy level would have enabled him to alter or embellish words and phrases to make the story into a beautiful, attractive and mysterious piece of literature. The Tango no Kuni Fudoki Itsubun version contains many elements of Daoist influence, and it is unclear whether they were present in earlier oral versions or not. According to Miura, there is a high possibility that Iyobe no Umakai no Muraji was thoroughly versed in Chinese, Daoism and the Japanese oral versions of the Urashima story, so he would have been able to mix these elements to embellish it, and then record it in the Fudoki document. ${ }^{81}$ The version in this text can be analysed as a mixture of Chinese influences, including expressions and the symbolic elements of Daoism, together with elaborated expressions of Japanese originality. ${ }^{82}$ However, again, the author of the

${ }^{80}$ Miura, 1989, 101-103.

${ }^{81}$ See Ooms, 2009, Ch. 6 Daoism, 132-153.

82 While the early Japanese Urashima tales as prose narratives are recorded in Chinese characters, the text is in hybridised Japanese language, which is not Chinese. On the written forms of Old Japanese, see Miyake, 2003, 19, 89; and Lurie, 2011, 225, 228. 
Urashima story in Tango no Kuni Fudoki Itsubun remains unidentified. (Further explanation of Daoism will be provided later. (See pp. 32-35, and 38).

In short, although the Tango no Kuni Fudoki Itsubun text dates from no earlier than 713, the Urashima story it contains may date from the Asuka Period (593-710 CE), making this text putatively the second earliest of the extant versions.

\section{Source No.3: Putative completed date of the story (700?), Nihonshoki (720)}

Source: Aston, W. G. (trans.). Nihongi, volume1-Chronicles of Japan from the earliest times to A.D. 697. New York: Cosimo, Inc., 2008, p.368. (First published in 1896.)

Source in Japanese: Sakamoto, Tarō, Ienaga, Saburō, Inoue, Mitsusada, and Ōno, Susumu (annot.). Nihonshoki (3). Tokyo: Iwanami Shoten, 2007, pp. 84-85 and p.432. (First published in 1994.)

Appendix 1: Number 3, pp. 118-119.

Unlike Tango no Kuni Fudoki Itsubun, the Urashima story outlined in Nihonshoki is recorded very briefly as though it were an actual historical event. It contains little literary description or rich poetic expression. Aston described the Nihonshoki (which he translated as Nihongi) as follows: "that in 714 , or two years after the completion of the Kojiki, the Empress Gemmiō (元明天皇 661-721) gave orders for the preparation of a national history, and the Konin Shiki (commentary on the Nihongi 日本紀, of the period 810-824) informs us that it was completed and laid before the Empress Gemmiō in A.D. 720 by Prince Toneri (舎人親王 676?-735?) and Yasumaro Futo no Ason (太安万侶? 723)." ${ }^{83}$ It took forty years to compile the Nihonshoki $(720 \mathrm{CE})$ as a governmental project and there are a bulky thirty volumes in total, which not only contain Teiki (帝紀 Records of Emperor's genealogy) ${ }^{84}$ and Kyūji (旧辞 Mythical Tradition), ${ }^{85}$ but also

\footnotetext{
${ }^{83}$ Aston, 2008, xi.

${ }^{84}$ Shimmura, 1993, 1746. Teiki is a genealogical record of Emperors.

${ }^{85}$ Shimmura, 1993, 653. Kyüji is a record of mythology and tradition, or recitation of them.
} 
documents from China and Korea, and it also features folklore that focused on genealogies derived from government offices and temples. Nihonshoki (720 CE) is written in an idiosyncratic classical Chinese style, and was the official governmental historiography representing the new nation-state of Japan to foreign countries, meaning China and Korea. ${ }^{86}$ That is perhaps the reason why the Urashima story in Nihonshoki is recorded differently in Nihonshoki from in Kojidan, Tango no Kuni Fudoki Itsubun and Manyōshū.

While the Urashima story in Nihonshoki is very short compared to Tango no Kuni Fudoki Itsubun and Manyōshu from the same Nara Period, the outline and the characters of the Urashima story share greater similarities with Tango no Kuni Fudoki Itsubun than with Manyōshū. It also seems that the Urashima story in Nihonshoki is written in a nonliterary-style or folktale style, but it is described rather formally, being presented as one of the chronicles of Japan. The author is not mentioned in Nihonshoki, and the Urashima story is merely described under the entry for the reign of putative King Yūryaku (a Yamato ruler in the second half of the fifth century). ${ }^{87}$

The previously mentioned commentary on the Urashima story in Nihonshoki, 語 在別巻 “there is another version of the story in existence”, suggests that there were no other recorded versions at the time that had a similar outline or story line apart from that which formed the basis of "Urashimako Den" in Kojidan or Tango no Kuni Fudoki Itsubun. Although the Urashima story in Nihonshoki is recorded under the Year 22 of the reign of Emperor Yūryaku, which was putatively around the year $478 \mathrm{CE}$, judging from the time of compilation of Nihonshoki in $720 \mathrm{CE}$, the Urashima story in Nihonshoki was, most plausibly, a summarised, shortened and concise version based on another recorded version, which was probably either the one referred to in "Urashimako Den" or that in Tango no Kuni Fudoki Itsubun. In short, the versions of the tale in Tango no Kuni Fudoki Itsubun and Nihonshoki were likely both based on the earliest extant version recorded by Iyobe no Umakai no Muraji.

\footnotetext{
86 Tada, 2008, 14-15.

${ }^{87}$ Sekai Daihyakka Jiten, “Yūryaku tennō” Kotobank, 2006. <http://kotobank.jp/word/\%E9\%9B\%84\%E7\%95\%A5\%E5\%A4\%A9\%E7\%9A\%87?dic=sekaidaihy akka\&oid=00330151>. Accessed on $10^{\text {th }}$ Jan, 2014.
} 


\section{Source No.4: Putative completed date of the story (720-740?), Manyōshū (400- 759?)}

Source: Keene, Donald (ed.). The Manyōshū, The Nippon Gakujutsu Shinkōkai

Translation of one thousand poems. New York: Columbia University, 1969, pp. 216-218.

Takagi, Ichinosuke, Gomi, Tomohide, and Ōno, Susumu (annot.). Nihon Koten

Bungaku Taikei vol.5, Manyōshū 2. Tokyo: Iwanami Shoten, 1959, pp. 384-387.

Appendix 1: Number 4, pp. 119-127.

Palmer (2011) describes Manyōshü: "Some of the earliest extant poetry written in Japan is included in an anthology known as the Manyōsh $\bar{u}$, or 'Collection of Ten Thousand Leaves.' This anthology in twenty volumes contains some 4,500 poems that are thought to span about 350 years to 759 CE. Many of them were probably transmitted orally at first, using the styles and devices of pre-literary oral tradition." 88 So the role of Manyōshū can be interpreted as the recording and compilation of ancient oral stories and poems as a collection along with the introduction of writing in Chinese characters. While the identity of the compiler of this anthology is not entirely clear, it is believed that Ōtomo no Yakamochi (大伴家持 717?-785) played a prominent role. ${ }^{89}$ In Manyōsh $\bar{u}$ it unequivocally specifies the author of the Urashima narrative poem as Takahashi no Mushimaro (高橋虫麻呂, date unknown but putatively from early eighth century), and is from the "Mushimaro Collection", Urashima of Mizunoe. ${ }^{90}$ Ōtomo no Yakamochi notes in Manyōshu that fourteen long narrative poems and nineteen short poems plus one other poem (旋頭歌 sedō $k a^{91}$ ) and other poems, including this Urashima narrative poem, were composed by Takahashi no Mushimaro. ${ }^{92}$ Also Inukai (1997) states that there are thirty-four of Takahashi no Mushimaro's poems in total in Manyōsh $\bar{u},{ }^{93}$ and continues that Takahashi no Mushimaro was a very unusual person,

\footnotetext{
${ }^{88}$ Palmer, 2011,417

${ }^{89}$ Palmer, 2011, 417.

${ }^{90}$ Keene, 1969, 214-215.

${ }^{91}$ sedoka (旋頭歌) is one of the forms of Japanese songs, which is 5-7-7 and 5-7-7 syllable patterns. Shimura, 1995, 1252.

${ }^{92}$ Shigematsu, 2006, 118. See also Miura, 1989, 112.

${ }^{93}$ Inukai, 1997, 109-112.
} 
being the most romantic poet of the Manyōshū anthology. Takahashi no Mushimaro writes only about beauty, and in his poem on the Urashima legend he uses his creativity to open up the story aesthetically. ${ }^{94}$ Endō (2013) also notes that the characteristic of Takahashi no Mushimaro's style is narrative, preferring unusual stories, and notes that "the lonely heart" is the literary essence of Mushimaro's poetry. ${ }^{95}$

There is no clue as to the year of completion of this Urashima narrative poem, but Takahashi no Mushimaro is described as serving the government in the early Tempyō period (729-749 CE), and was later appointed as an official in Hitachi Province. ${ }^{96}$ Thus, it may be surmised that Takahashi no Mushimaro could have accessed and read previously recorded Urashima stories, including the versions in "Urashimako Den", Tango no Kuni Fudoki Itsubun and Nihonshoki. Therefore, it is feasible that Takahashi no Mushimaro would have been able to compose the Urashima narrative poem in Manyōshū with reference to "Urashimako Den", Tango no Kuni Fudoki Itsubun (post $713 \mathrm{CE})$ and Nihonshoki (720 CE) as source materials. It is also likely that the oral Urashima story was very popular and well known at that time. This poem in Manyōshu therefore may have been based on multiple sources. However, he did not merely imitate earlier versions, but he chose to present a very beautiful romanticised version of the Urashima tale as a narrative poem.

\section{Comparison of motifs: From the putative original source of the version recorded} as "Urashimako Den" in Kojidan to Tango no Kuni Fudoki Itsubun, Nihonshoki and Manȳ̄shū.

\section{Comparison of motifs 1: the main character names.}

"Urashimako Den" in the Kojidan translation version can be seen in Appendix 1, and this is regarded as putatively the original written source of the Urashima story, as explained above. As can be seen from Table 1 (see pp. 101-108), the main character's

\footnotetext{
94 Inukai, 1997, 114.

95 Endō, “Takahashi no Mushimaro”, Nihon Daihyakka Zenshū, 2013. <http://100.yahoo.co.jp/detail/\%E9\%AB\%98\%E6\%A9\%8B\%Е8\%99\%AB\%Е9\%BA\%ВB\%Е5\%91 \%82/\#header $>$. Accessed on $25^{\text {th }}$ Sep, 2013.

96 Endō, “Takahashi no Mushimaro”, Nihon Daihyakka Zenshū, 2013. <http://100.yahoo.co.jp/detail/\%E9\%AB\%98\%E6\%A9\%8B\%E8\%99\%AB\%E9\%BA\%BB\%Е5\%91 $\% 82 / \#$ header $>$. Accessed on $25^{\text {th }}$ Sep, 2013. See also Shimmura, 1993, 1570.
} 
name is very similar when compared to the next three versions in chronological order, in Tango no Kuni Fudoki Itsubun, Nihonshoki and Manyōshū. Mizunoe no Ura Shimako as the name of the main character is used in common among these four texts, which the main character's name in "Urashimako Den" seems to be described simply and there is no embellishment or extra information, as may be expected if this is the original recorded version of the Urashima story. The main character's name is described in “Urashimako Den" as follows: Mizunoe (水江), which is a place name; Ura (浦) means a bay, shima (嶼, 島, 嶋) means an island, and $k o$ (子) means a young person, a child, a son, or a part of a Japanese given name. So in regards to the combination of Chinese characters, Shimako is a given name. However, "no" can be translated as "of" or "from". For these reasons, the interpretation of the names are analysed as follows:

"Urashimako Den" in Kojidan: Mizunoe no Ura Shimako (the location name + the location + personal name $=$ Shimako from the Bay of Mizunoe).

However, analyses of the place names in "Urashimako Den" will be avoided due to questions of authenticity, as this may be an embellishment or addition to the story later by the Kojidan editor. Tango region, Yosa County, and Suminoe Bay all appear in “Urashimako Den”, but these will be analysed later.

There are three different names that appear in the Nara Period texts: Tsutsukawa Shimako, Mizunoe no Ura no Shimako in Tango no Kuni Fudoki Itsubun, Tsutsukawa no Mizunoe no Urashima no ko in Nihonshoki, and Mizunoe no Urashima no ko in Manyōshū (see pp. 101-108). These are quite similar to "Urashimako Den," apart from the place name Tsutsukawa (筒川, 管川).

TKFI: ${ }^{97}$ Tsutsukawa Shimako: (the location name + personal name = Shimako "Island Boy" of Tsutsukawa), Mizunoe no Ura no Shimako (the location name + the location + personal name $=$ Shimako from the bay of Mizunoe $)$.

Nihonshoki: Tsutsukawa no Mizunoe no Urashima no Ko: (the place name + the place name + family name + description of age $=$ the young person of the Urashima "Bay Island" [family] of Mizunoe in Tsutsukawa).

${ }^{97}$ TKFI here means an abbreviation of Tango no Kuni Fudoki Itsubun. 
Manyōshū: Mizunoe no Urashima no Ko (place name + family name + description of age $=$ the young person from the Urashima "Bay Island" [family] in Mizunoe).

From the interpretation above, the main character was described in common by means of the location name of Tsutsukawa in Tango no Kuni Fudoki Itsubun and Nihonshoki, indicating that these two texts may be related, but the Manyōshū version does not record the location name of Tsutsukawa. However, the given name Shimako is used in "Urashimako Den" and Tango no Kuni Fudoki Itsubun, but the other two Nara period texts describe him as Mizunoe no Urashima no Ko. This could be a confusion of Chinese and Japanese readings because "no" can be inserted anywhere in this phrase as long as it comes after a noun. Therefore, in putatively the earliest extant texts of "Urashimako Den" and Tango no Kuni Fudoki Itsubun, it does not record the family name, but the first name of Shimako from Tsutsukawa only appears in Tango no Kuni Fudoki Itsubun. However, the usage of " $n o$ " in the gloss and elimination of the Tsutsukawa combination creates the meaning, a 'young person from Urashima', and as a result, this appears to have led to a change in the name of the main character in later periods.

\section{Comparison of motifs 2: Sumiyoshi Taisha 住吉大社 (Sumiyoshi Grand Shrine) and Chiastic reversal}

Similar Chinese characters and place names in common in the main characters can be identified, including Tsutsukawa, Mizunoe, Urashima and Shimako. Place names such as Yosa in the province of Tamba, and Hioki village in Yosa, are place names they share in common.

Notably, the place name Suminoe in "Urashimako Den" and Manyōshū indicates a different name among these four documents. It is noteworthy that the Chinese characters 墨吉 (Sumiyoshi) in Manyōshū are a very common written representation of the phonemes for this location name. This is normally glossed Sumiyoshi, rather than Suminoe, in modern Japanese. However, attention should be drawn to the fact that most modern Japanese scholarly redactions of Manyōsh $\bar{u}$ gloss this as Suminoe. The second 
character is the same as in Sumiyoshi Taisha (住吉大社), but likewise many modern redactions of Manyōshū also gloss this as Suminoe. ${ }^{98}$

Techniques of orality were still strongly influential in the Nara Period and the aforementioned versatile Iyobe no Umakai no Muraji and Takahashi no Mushimaro's creativity and originality can be seen in this place name in this respect too. The main character names of the Urashima story are described in "Urashimako Den", Tango no Kuni Fudoki Itsubun and Nihonshoki as Mizunoe no Urashima. However, the location name Suminoe appears in "Urashimako Den" and Manyōshu, and it may be hypothesized that this is because Iyobe no Umakai no Muraji and Takahashi no Mushimaro used chiastic reversal. Palmer (2000) argues that chiastic reversal amalgamated to produce one complicated word-play inherent with multiple meanings, for example, sasa 'bamboo grass' is evocative of shino, another variety of bamboo grass. ${ }^{99}$

Palmer continues that the same characters were applied to words that were closely associated semantically in people's minds. ${ }^{100} \mathrm{Mi}-z(d) u$ of Mizunoe, and Su-mi of Suminoe are arguably a reversal of syllables, and may be explained as follows. Kindaichi (1978) states that the Old Japanese of the Nara and pre-Nara Periods had several striking characteristics, including, for example, that voiced consonants and the $r$ series ( $r a, r i, r u, r e, r o$ ) never came at the beginning of a word. ${ }^{101}$ Thus, in the pre-Nara and Nara Periods, chiastic reversal of midu (みづ) could not have become dumi (づタ). Given that Old Japanese midu (みづ) has evolved into mizu (みず) in Modern Japanese, it is here surmised that chiastic reversal of midu in Old Japanese resulted in a similar shift from $t u$ (つ) to $s u$ (す), which had to be unvoiced at the start of a word. In other words, chiastic reversal in the place name Midunoe produced the place name Suminoe.

The important point here is that this kind of reversal is not based on the visual (i.e., written) evidence, but on the pronunciation in an orally transmitted story. While we cannot know exactly how people in ancient Japan pronounced words, it is

\footnotetext{
${ }^{98}$ Manyōshū kōhon sakusei data base sakusei iinkai. <http://www.manyou.gr.jp/SMAN_1/pass/09/kaku.cgi?kaku=1740003>. Accessed on $13^{\text {th }}$ Dec, 2013.

${ }^{99}$ Palmer, 2000, 86.

${ }^{100}$ Palmer, 2000, 86.

${ }^{101}$ Kindaichi, 1978, 114.
} 
established that word-play did not need to be precise, merely close enough for listeners to correlate the sounds and meanings.

Both Iyobe no Umakai no Muraji and Takahashi no Mushimaro would have been familiar with this oral technique, and applied their versatile knowledge to the place names that also contributed to their originality. Or perhaps Takahashi no Mushimaro followed this technique from Iyobe's recorded version.

Place names are used to identify a relationship with the author and the locality. They are also useful for identifying the geographical origins of the Urashima story and its timeline; to determine how old the story is; and which version may be the oldest, because the place names are not the same in each version. The place names pre-existed at this period, and characters were applied to them to represent those sounds in writing. In the early Nara Period the kanji (Chinese characters) for place names had not yet become entirely fixed, so a single place name was often written with different characters, such as 澄 (sumi), 墨 (sumi) or 住 (sumi). However, the Urashima stories were written around the same time, so the original Urashima story might have spread from one place to the other, and if this is the case, the place names mentioned and their identification or interrelationship might provide a logical clue to the tale's origin.

Tanigawa (1995) explains that he was born and raised in Minamata, Kumamoto Prefecture, where he often dived in the water when he was a child, which locally they called sити. Even in Okinawa dialect to dive and submerge under the water is referred to as sumu. ${ }^{102}$ During his dialect field trip research in Kyūshū and Okinawa areas, Tanigawa found that in most towns where he researched people used sumu to describe diving or submerging under the water, and even as far east as Kōchi Prefecture the dialect has sити meaning to dive under the water. Arguably, then, sumu is a verb that indicates diving and submerging under the water, and is an otherwise obsolete language usage from the Manyōshu period (350? 759CE), but the noun sumi "diving" still remains in place names such as Suminoe. Diving was a notable occupation of the ancient ama group of seafarers, fisherfolk and divers, so it may be deduced that the

102 Tanigawa, 1995, 66. 
language used by them did not completely disappear but persisted in place names associated with their settlements. ${ }^{103}$

Moreover, attention should be drawn to the place name of Suminoe in the "Urashimako Den" version because this is the first time that Suminoe is mentioned in Table 1 (see pp. 101-108). Suminoe as a location or place name sounds familiar to present-day Japanese people, due to the popularity of Sumiyoshi Taisha (Sumiyoshi Grand Shrine) in Osaka and branch Sumiyoshi Shrines throughout Japan. Sumiyoshi Grand Shrine is the main shrine of all the Sumiyoshi shrines, of which there are over two thousand all over Japan. ${ }^{104}$ They enshrine Sumiyoshi Taijin (the Great Gods of Sumiyoshi), who are named as Sokotsutsu no Onomikoto (底筒男命), Nakatsutsu no Onomikoto (中筒男命), and Uwatsutsu no Onomikoto (表筒男命). ${ }^{105}$ These three Great Gods are related, and are known through the Izanagi and Izanami story in Japanese mythology from Nihonshoki and Kojiki. The legendary Okinagatarashi hime no mikoto (気長足姫尊), ${ }^{106}$ also posthumously regarded as the Empress-Consort Jingū (神功皇后), obtained power from the Sumiyoshi Taijin when she crossed the sea to go to Silla (新羅 an ancient Korean kingdom: BC57-935 CE or 356-935 CE), ${ }^{107}$ and was putatively enshrined in the year $211 \mathrm{CE}$ according to Teiō Hennenki (帝王編年記 Annals of the Emperor) from Sumiyoshi Taisha website homepage. ${ }^{108}$ Therefore, Sokotsutsu no Onomikoto, Nakatsutsu no Onomikoto, Uwatsutsu no Onomikoto, and Okinagatarashi hime no mikoto have been regarded as Sea Gods and Goddess ever since. ${ }^{109}$

In addition to this, Tanigawa (1995) argues the case for a close relationship between the Sumiyoshi Deities and the places that included tsutsu 筒 in their name. Several place names including the element tsutsu can be found in Dai Nihon Chimei

\footnotetext{
103 Tanigawa, 1995, 72.

${ }^{104}$ Sumiyoshi Taisha, about a history and a tradition of Sumiyoshi Taisha.

${ }^{105}$ Sokotsutsu no Onomikoto (底筒男命), Nakatsutsu no Onomikoto (中筒男命), and Uwatsutsu no Onomikoto (表筒男命) are the meanings of the bottom of the sea, the middle of the sea and the surface of the sea who transformed the deities. Öbayashi et al, 1997, 182.

106 Sumiyoshi Taisha, aramashi.

${ }^{107}$ Shimmura, 1993, 1306.

${ }^{108}$ Teiō Hennenki is believed to have been compiled in Kamakura period. <http://kotobank.jp/word/\%E5\%B8\%9D\%E7\%8E\%8B\%E7\%B7\%A8\%E5\%B9\%B4\%E8\%A8\%98 ?dic $=$ sekaidaihyakka\&oid $=00243412>$. Accessed on $13^{\text {th }}$ Dec, 2013.

${ }^{109}$ Sumiyoshi Taisha, gūji aisatsu.
} 
Jisho (大日本地名辞書 Large Dictionary of Japanese Place Names), ${ }^{110}$ and they are related to Sumiyoshi Deity and the Sea God, including the most well-known tsutsu place name of Tsutsukawa in Yosa County, in the Tango region. ${ }^{11}$ Tanigawa continues that it is evident that there is therefore a close relationship between the place name of Suminoe and Tsutsukawa, which implies the Sea God. ${ }^{112}$

Obbayashi et al (1997) explain that there are various theories about the meaning of -tsutsu concerning the aforementioned three Great Gods, but there is no definitive theory. For example, the first "tsu" as a Japanese possessive particle, and the second “tsu" as harbour ( $t s u$ 津), so the three Great Gods could be interpreted as Sokotsutsu (底 つ津) meaning the bottom of the harbour, Nakatsutsu (中つ津) meaning the middle of the harbour, and Uwatsutsu (上つ津) meaning the surface water of the harbour.

Another theory is that it means a mallet-shaped stick and a group of oars, or a very thick pillar as a mast on a Japanese boat (it is certain that these Gods are closely related to the sea). ${ }^{113}$ On theother hand, Tanigawa (1995) urges that $t s u t s u$ means a snake in ancient Japanese, and tsutsu and tsuchi were synonyms of “snake”, such as Tsuchinoko (ツチの) 子), a mythical creature, which still to this day contains the meaning of snake. ${ }^{114}$ The ancient ama group of people in Japan also regarded their ancestors as a group of sea snakes and enshrined them as Gods. ${ }^{115}$ Therefore, there may be another putative relationship with the place name of Tsutsukawa and Suminoe, Sumiyoshi Shrine, the sea and the Sea Gods in the Urashima story.

Manyōshü describes the character of the daughter of the Sea God whom Shimako visits. Although Tango no Kuni Fudoki Itsubun mentions her as the daughter of a God or Goddess, it does not unequivocally use the word Sea God. From this evidence and the relationship between Sumiyoshi Grand Shrine and the EmpressConsort Jingū, it is, however, clear that they are all related to the sea. Since chronologically it appears to be a very old version, the Urashima tale in Manyōsh $\bar{u}$ may perhaps be regarded as based on the first recorded Japanese version of the Urashima

\footnotetext{
${ }^{110}$ Dai Nihon Chimei Jisho has six volumes and was written in 1900-1907 by Yoshida, Tōgo (historian and geographer, 1864-1918).

111 Tanigawa, 1995, 23, 55-66.

112 Tanigawa, 1995, 58.

113 Ōbayashi et al, 1997, 182.

114 Tanigawa, 1995, 60.

115 Tanigawa, 1995, 40.
} 
story that Takahashi no Mushimaro crafted from his imagination and embellished with his concept of beauty, adding Japanese features such as the Sea God and Tokoyo. It is as if the Urashima story in Manyōsh $\bar{u}$ focuses largely on an ama group or coastal area of Suminoe or Mizunoe at that time. Likewise, Takahashi and Senda (1991) argue that ama people (coastal dwellers) originally brought the Urashima prototype story from near Lake Dongting (洞庭湖 $\mathrm{J}:$ doteiko) ${ }^{\mathbf{1 1 6}}$ in China, when their ancestors first arrived in Japan. ${ }^{117}$ Kimishima (1984) has translated into Japanese the story called The female dragon in Lake Dongting, which is strikingly similar to Japanese tales of Urashima Tarō. ${ }^{118}$

In short, the reference to the Sumiyoshi deities links the Urashima myth to the cultural complex associated with these ocean deities who were principally worshipped by coastal dwelling divers and fisher folk known as ama. ${ }^{119}$

\section{Comparison of motifs 3: the turtle and the woman}

The Urashima story in Manyōsh $\bar{u}$ is the only version that does not contain a pair of characters comprising the man Urashima and a turtle. There is no mention of the turtle at all in this version, which is a significant difference when compared to all other fourteen sources in Table 1 (see pp. 101-108). The turtle plays a very important role in

\footnotetext{
${ }^{116}$ Lake Dongting locates in north-eastern Hunan province, China. Sekai Daihyakka Jiten, "Dōteiko", Kotobank, 2006.

<http://kotobank.jp/word/\%E6\%B4\%9E\%E5\%BA\%AD\%E6\%B9\%96?dic=sekaidaihyakka\&oid= 00251560>. Accessed on $28^{\text {th }}$ April, 2014.

117 Takahashi and Senda, 1991, 213. See also Kumar, 2009, 73-103.

${ }^{118}$ Kimishima, 1984, 12 and 76-79, which she cites from the Chinese: 関于海竜王与竜女故事的分析 (Folktale analysis of the Dragon King of the Sea and the Dragon Princess) by 季岳南??? ? In this version, the Dragon Princess, distressed by a gale, seeks help from an unnamed young fisherman on Lake Dongting. She gives him a pearl that she tells him has the power to divide the waters so that he may visit her in the Dragon King's Palace. Then she turns into a golden fish and dives into the lake. The fisherman does as instructed and follows her. They marry and live happily until he thinks of his old mother and wishes to go home and see her. The Dragon Princess tells him that once he has returned home he will never be able to return to this palace. She implores him to stay, but he insists on leaving. She gives him the pearl in a casket and tells him to call her name whenever he misses her, but she strictly admonishes him never to open the casket. Back in his village, he recognises nobody, and the villagers tell him that a long time ago there was once an old woman who awaited her son who never returned, but she had long since died. Unthinkingly, in his grief, the fisherman opens the casket. White smoke puffs out and he turns into an old man. Later, when he dies, the waters of Lake Dongting surge up, due to the long sigh of the Dragon Princess for her husband. Whenever the level of the water in the lake changes, it is said to be caused by her sighing.

${ }^{119}$ Takahashi and Senda, 1991, 213. See also Senda, 1990, 93-94, and 112.
} 
the Urashima stories in general, because the turtle assumes the role of messenger from the Sea, the Sea God, or the Sea King, or is an intermediary, or a character to connect the normal world and the sea world, the world of human beings and the God, or reality and utopia. From a modern Japanese point of view, it is very hard to image this story without reference to the turtle, so integral has it become to the Urashima story. Unlike later versions, Manyōshū contains no connections, triggers, reasons or motifs for Urashima to rescue a turtle. The modern stereotypical Urashima story is that in return for the rescue, Urashima is invited to the Undersea World and receives the souvenir box. However, the Urashima story is actually coherent even without the motifs of the turtle or return for a rescue. In this Manyōsh $\bar{u}$ version, Urashima's meeting with the daughter of the Sea God and falling in love with her is sufficient motive in itself for his accompanying her to the Sea Palace in Tokoyo.

Morohashi (1971) states that the turtle is one of the Four Benevolent Animals (四靈 shirei). ${ }^{120}$ In other versions it is described from the Chinese perspective as Ao, an enigmatic creature that is highly symbolic of longevity. ${ }^{121}$ The Ao is usually said to be an enormous sea turtle, though another tradition describes it as a giant fish. ${ }^{122}$ The crane is said to live one thousand years, while the turtle lives for ten thousand years. The turtle is therefore symbolic of Urashima gaining longevity under the sea. The character of the turtle in the Urashima story appears to be influenced by Chinese ideology: especially the first appearance of the turtle in "Urashimako Den", the turtle described as five-coloured in Tango no Kuni Fudoki Itsubun and the big turtle in Nihonshoki are clearly influenced by Taoist thought. It is not from Buddhism that the five colours of blue, red, yellow, white and black became sacred, but in fact the five sacred colours are based on Confucianism, and Daoism spread the notion of five colours to the public, such that it became popularized in China. ${ }^{123}$ In Baopuzi (Book of the Master Who Embraces Simplicity, 抱朴子 J: Hōbokushi) ${ }^{124}$ it is mentioned that the ten

\footnotetext{
${ }^{120}$ Morohashi, 1971, vol.12, 1151. Four Benevolent Animals are Qilin, Phoenix, Turtle and Dragon in the Book of Rites (raiki 礼記, Liji in Chinese, unknown date). Sekai Daihyakka Jiten, "Shirei", Kotobank, 2006. <http://kotobank.jp/word/\%E5\%9B\%9B\%E9\%9C\%8A>. Accessed on $21^{\text {st }}$ Feb, 2014.

${ }^{121}$ Eberhard, 1986, 20.

122 Eberhard, 1986, 20 and 294.

123 Takahashi and Senda, 1991, 74-76.

${ }^{124}$ Baopuzi (Hōbokushi 抱朴子) was written in 317CE by Ge Hong (葛洪) from Jin Dynasty. Shimmura, 1993, 2345. The Inner Chapters of Baopuzi, the Master Who Embraces Simplicity and the Outer Chapters of the Master Who Embraces Simplicity. Ge used the Daoist Inner Chapters to substantiate the reality of immortality and convey the methods for realizing it, while the Confucian
} 
thousand years of a turtle have five colours of blue, red, yellow, white and black in Daoism, the five colours being the colours of the Gods that were systematized in the fourth century AD. ${ }^{125}$ Therefore, it can be concluded that in terms of the turtle described in the Urashima version in Tango no Kuni Fudoki Itsubun, the character of the five-coloured turtle is the product of a syncretic mixture of Daoism, Confucianism and thought concerning Japanese deities. In addition, the relationship between the turtle and the Urashima story is relevant, as it is not only a creature symbolic of longevity, but also it symbolises Urashima's longevity itself, in that he spends a long time with the woman he loves at the Sea Palace, Tokoyo or Mt. Hōrai.

A significant variation is in the description of the female protagonist. In Manyōsh $\bar{u}$, Urashima meets a woman at the border of the sea and the land, so he actually meets the woman herself and they go to the Sea Palace together. In the three other versions (“Urashimako Den”, Tango no Kuni Fudoki Itsubun and Nihonshoki), by contrast, Urashima catches a turtle which then turns into a woman, and they then go to Mt. Hōrai.

\section{Comparison of motifs 4: Mt. Hōrai and Tokoyo}

Urashima and the Turtle-Princess do not marry in "Urashimako Den", but they marry in other versions of the story. However, the locations of the place where they go are all different. It is described in "Urashimako Den" that Urashima and the woman go to Mt. Hōrai Palace in Mt Hōrai; in Tango no Kuni Fudoki Itsubun, Urashima and the woman go to Mt. Hōrai which is located on an island in the sea; but in Nihonshoki, Mt. Hōrai is described as being in the sea; and in Manyōsh $\bar{u}$, Urashima and the woman go to the Sea Palace which is in Tokoyo, and they do not visit Mt. Hōrai at all.

In terms of translation, Mt. Hōrai (蓬莱山) is translated as the Mountain of Immortality, and Tokoyo (常世) as the immortal world located across the sea. Mt.

Outer Chapters describe the problems afflicting the secular world and his proposed solutions. Knapp, “Gi Hong”, 2005. <http://www.iep.utm.edu/gehong/>. Accessed on $1^{\text {st }}$ June, 2013. See also Ooms, 2009, 150.

125 Takahashi and Senda, 1991, 74-76. 
Hōrai was believed in ancient China to be a utopia where immortals (仙人 sennin) live, and is an imaginary place which is located far beyond the sea to the east.

In contrast, Tokoyo is a strange or a foreign land, and is a utopia in which deities live, according to the mythology in Kojiki; it is also located far beyond the sea, and it is the meaningful eternal world. ${ }^{126}$ Shimode (1993) explains that there are many theories about Tokoyo, being one of the well-known world views that the people had in ancient Japan, but the theory of Motoori Norinaga (1730-1801) is still commonly held. ${ }^{127}$ There are three meanings of Tokoyo: first is Tokoyo 常夜, which means 'everlasting night', as in the passage on Amaiwato ("Heavenly Rock Cave") in Kojiki and Nihonshoki; the second meaning is Tokoyo 常世 which means 'everlasting world'; and the third meaning is what is called Tokoyo no kuni 常世国, which does not indicate a specific country but is in a far distant place in any direction, from which there is no return. ${ }^{128}$

Miura (2006) explains that there are various different worlds in mythology such as Takama no hara (高天原 where Gods live) in the sky, Ashihara no Nakatsukuni (葦 原中国 our normal world) where people live on earth, Yomi no kuni (黄泉国 the underworld, the world of death or afterlife) that exists at the end of a cave connected to our living world (Ashihara no nakatsukuni), Watatsumi (海神 the Sea God's) world under the sea, and Tokoyo no kuni located at the far distant end of the horizon. ${ }^{129}$ People in ancient times in Japan had different world views; such as those depicted in Kojiki, with a combination of a vertical three-layered structure (the sky, the earth and the underworld) and the horizontal world view. ${ }^{130}$ Miura continues on to point out that a vertical world view is a characteristic of the northern, terrestrial, way of thinking, such as in Siberia, whereas on the other hand, a horizontal way of thinking is a characteristic of the southern (Pacific, oceanic) way of thinking. ${ }^{131}$

Therefore, while Mt. Hōrai is believed to be an immortal world, a view from Chinese Daoism, Tokoyo is not a place or world under the water, or the land of

\footnotetext{
${ }^{126}$ Miura, 1989, 57-58.

${ }^{127}$ Shimode, 1968, 112-113 and 164-165.

${ }^{128}$ Shimmura, 1993, 2544.

${ }^{129}$ Miura, 2006, 18.

${ }^{130}$ Miura, 2006, 19. See also Hino, 2012, 1052 and 1061.

${ }^{131}$ Miura, 2006, 36.
} 
eternity, ${ }^{132}$ but is the place of everlasting night or an everlasting world. So the Mt. Hōrai description of the home of the princess in "Urashimako Den" is closer to the view from Chinese Daoism, while the description of the home of the daughter of the Sea God in Manyōshü is closer to the ancient Japanese mythology rather than the Chinese concept of Mt. Hōrai. Manyōshū does not mention Mt. Hōrai, but instead, Urashima and a woman go to Tokoyo, everlasting night and an everlasting world, where the deities live according to the mythology in Kojiki. Therefore, Manyōshū more nearly accords with the concept of gods and the deities appearing in Japanese mythology.

\section{Comparison of motifs 5: Pleiades and Hyades}

The Urashima story in Nihonshoki is too short to analyse compared to the other Urashima versions, but in Tango no Kuni Fudoki Itsubun, there is a richness of expression that does not appear in "Urashimako Den", Nihonshoki or Manyōshū. One of the best examples of this is a description of the constellations Pleiades and Hyades. A description of the Pleiades and Hyades is mentioned only twice out of the fifteen versions in Table 1 (see pp. 101-108). Miura (1989) comments that the Pleiades and Hyades, like other stars, rarely appear in ancient Japanese documents. ${ }^{133}$ Since reference to the Pleiades and Hyades occurs only twice, and one of these can be seen in Tango no Kuni Fudoki Itsubun, this motif may be seen as an embellishment by Iyobe no Umakai no Muraji. The aforementioned Umakai, a person of great knowledge in the Asuka and Nara periods, was able to embellish the Urashima story based on the source story of "Urashimako Den", a putatively earlier version, because he was well-versed in literature. It seems that this version of the Urashima story in Tango no Kuni Fudoki Itsubun could be the model for later periods. It is noteworthy that the stars were doubtless very important tools for navigation at that time, and the aforementioned ama people would have been familiar with them. The description of the constellations Pleiades and Hyades was thus doubtless an important element in narrating their relationship with the sea.

\footnotetext{
132 Shimode, 1968, 164.

${ }^{133}$ Miura, 1989, 82.
} 


\section{Comparison of motifs 6: Elapsed Time and the number three}

Tango no Kuni Fudoki Itsubun clearly describes that the place where Urashima and the woman go provides food and drink, the length of his stay felt like three years, they sing songs, three hundred years elapse, a sweet fragrant odour comes out from the souvenir box, and the aged Urashima wanders around. In contrast, "Urashimako Den" describes that the length of their stay is long, Shimako and the maiden drink a golden elixir, milk of limestone, miraculous infusions and sake, and it is a purple cloud that comes out from the souvenir box.

In Manyōshu, it also describes that the length of their stay is a long time, just three years elapses, a white cloud comes out from the souvenir box, and Urashima dies at the end. The Urashima story in Tango no Kuni Fudoki Itsubun is a very literary story in its description of smoke and the elapsed time. Differences are noticeable in the elapsed time of three hundred years and three years respectively. The length of three hundred years during which the main character of Urashima spends time with his partner is sufficiently long to embellish the story, so as to strike the readers' imagination as an unthinkable length of time for a human lifespan. In contrast, the action takes place over a mere three years in Manyōsh $\bar{u}$, because Takahashi no Mushimaro's love-romance version perhaps aims to attract readers to the sense of "a lonely heart", and the length of three years probably gives the readers a greater sense of reality. Even so, three years is long enough for Urashima to be away from home and for everything to be different when he returns. Nevertheless, if it were three hundred years, it would not lose credibility as a romantic or "a lonely heart" narrative poem.

However, now a question arises in regard to the expression of the number three: the elapsing time of three years and three hundred years. Miura (1989) states that the number three is often used in Japanese mythology, but the number three, or three years to describe a long period of time generally is not seen in Chinese deity stories. It is therefore understandable that the number three was used in the Urashima stories in Tango no Kuni Fudoki Itsubun and Manyōshū as it is a feature of Japanese mythology, and the three hundred years is a narrative exaggeration of three years. ${ }^{134}$ Moreover,

${ }^{134}$ Miura, 1989, 146. 
"Urashimako Den" can be regarded as not only based on non-Japanese mythological thought, but also that it is influenced greatly by Chinese orality and story-telling.

\section{Comparison of motifs 7: To die or not to die, the fate of Urashima}

The death of Urashima is specified only in Manyōsh $\bar{u}$, and thus provides another reason to suggest that the Urashima narrative poem in Manyōsh $\bar{u}$, by Takahashi no Mushimaro, is a different and independent version. The description of the death at the end of the narrative shows Mushimaro's artistic talent and romantic description of love. Without love Urashima can no longer live, and there is no way for him to survive without seeing the woman whom he still loves. Also it is made clear by his death that Urashima cannot be an immortal even though he had been to Tokoyo, arguably the place or the world of everlasting night. So Mushimaro may have preferred not to describe Urashima as vacant-minded, or as vague and wandering, because he had left the woman and returned to his home town from Tokoyo. Having returned to his real world, so being human, Urashima had to teach to the end of his life. This Manyōsh $\bar{u}$ Urashima story appears to have been created by Takahashi no Mushimaro with emphasis on the peculiarity of Japanese-originated mythological themes rather than Chinese influenced ones. Compared to this, Shimako only wanders around in Tango no Kuni Fudoki Itsubun and is not described in detail. Similarly in "Urashimako Den" and Nihonshoki, it does not describe Shimako's fate, nor does it give the reader a clear cut ending.

\section{Comparison of motifs 8: The colour purple}

Purple draws attention because it is only mentioned in "Urashimako Den". As can be seen in Appendix 1 Translation, number 1 (see pp. 112-114), "It is said that when he yearned for her, and when he opened the treasure box that she had given him, purple smoke puffed out from the box, soared to the sky, and flew away to the west". Fukunaga (1987) explains that purple is a colour of respect and its original ideology derives from China in the third to second century BC. According to this, Gods of the universe live in the Palace where purple was a symbolic colour of respect, and the Gods were interpreted to deify the Big Dipper that cast a purple light from the sky. In the 
second century $\mathrm{CE}$ and the fourth to sixth century $\mathrm{CE}$, the palace where the Emperors lived was called the Hidden Purple Palace, especially during the Northern Wei dynasty (386-534 CE) ${ }^{135}$ whose official religion was Daoism. ${ }^{136}$ In addition, purple is a colour of the Palace where the Emperor and immortals live, and is also frequently associated with both heaven and the Emperor; the Chinese Imperial Palace was known as the 'Purple Region'. 137

Therefore, purple was regarded as a very respectful and ancient colour that is derived from symbolism related to Chinese Taoist ideology. As the putative original record of the Urashima story in "Urashimako Den" contains a purple cloud in the story, it signifies stronger Taoist ideology than Shintō compared to other versions of the Urashima story.

\section{Conclusions regarding the Urashima story in the Asuka and Nara Periods}

The Urashima tale in oral storytelling was probably well known in some parts of Japan long before it was recorded in writing. From a chronological point of view, "Urashimako Den" is estimated in the present study as the oldest recorded version of the Urashima story or very largely based on it from the characteristics of its vocabulary and its usage. In its interpretation, it is influenced by Chinese ideology, including Daoism from China (such as reference to Mt. Hōrai). Tango no Kuni Fudoki Itsubun is a well embellished story of mature literature, and it is also influenced by Chinese ideas, such as the character of the five-coloured turtle which is the product of a mixture of Taoist and Confucian thought on the Pleiades and Hyades, and Mt. Hōrai, and the originality of Japanese songs (tanka).

A very short and simplified "historical" account was then recorded in Nihonshoki that noted at the end "there is another volume of this tale in existence." This indicates that there had been a previous written version of the Urashima story in existence by the time Nihonshoki was completed in 720. In addition, it seems from its description that Nihonshoki was derived either from the prototypes of "Urashimako

\footnotetext{
${ }^{135}$ Daijirin, "Gi”, kotobank, 2006. <http://kotobank.jp/word/\%E9\%AD\%8F?dic=daijisen>. Accessed on $8^{\text {th }}$ Jan, 2014.

${ }^{136}$ Fukunaga, 1987, 14-15.

${ }^{137}$ Morohashi, 1971, vol.8 992. See also Eberhard, 1986, 242-243.
} 
Den" or Tango no Kuni Fudoki Itsubun, but Nihonshoki had to be a shorter and more simplified version due to its historical purpose. Finally, the Manyōshū version by Takahashi no Mushimaro, who was very creative and romantic, seems to have been based on a Japanese original. This deity-based Urashima version is significantly different from the "Urashimako Den", Tango no Kuni Fudoki Itsubun or Nihonshoki. As a result, there are three different versions of Urashima stories after the prototype of "Urashimako Den", and these three versions were recorded at a similar time; and although they developed differently, they are in the lineage of "Urashimako Den". 


\section{CHAPTER 4: Heian Period (794-1185 CE) ${ }^{138}$}

\section{Historical overview: The Heian Period (794-1185 CE)}

Heian literature insisted on elegance and sentimentality with an aristocratic flavour, and was centred on the great success of high class female authors and kana literature. Chinese poetry was also established in the early Heian Period, and tales and stories related to the general public were established during the latter part of the Heian Period. ${ }^{139}$ In addition, in the traditional grand narrative of Japanese literary history, the Heian Period is presented as the age in which poetry in Japanese (waka) finally gained status as one of the highest literary arts through the first imperial waka anthology, the Kokinshū (古今集 Collection of Poems Ancient and Modern, 905 CE) Makura no Sōshi (枕草子 The Pillow Book, post $1000 \mathrm{CE}$ ), Buddhist and Confucian texts (in classicalstyle Chinese) and Chinese histories and poetry collections ranked above waka, and at the bottom were narrative texts in kana. ${ }^{140}$ Miura (1989) mentions that classical Chinese style (kanbuntai) Urashima stories can be found in this period; however, the first descriptive Urashima story in kana, in waka form, a traditional style of Japanese poem of thirty-one syllables, appeared in Gosenwakashū (後撰和歌集 Later selected collection of Japanese poetry) in 955-958 CE, composed by a female poet, Nakatsukasa (中務 911?-988? CE, mid Heian Period). ${ }^{141}$

The Urashima story in the Heian Period (794-1185 CE) becomes more complicated than in the previous Asuka Period and Nara periods in terms of the appearance of the texts and the Urashima storyline. A pair of Urashima stories, "Urashimako Den” and "Zoku Urashimako Denki” appears in Gunshoruijū, published in 1819 CE. However, it is estimated that "Urashimako Den" was not written in the nineteenth century or even around that time, but after the middle of the ninth century, due to its style of description and the names of the characters. Likewise, "Zoku Urashimako Denki" is believed to have been written in 920 CE or 932 CE. ${ }^{142}$

\footnotetext{
138 Shimmura, 1993, 2296.

${ }^{139}$ Shimmura, 1993, 2296.

${ }^{140}$ Adolphson et al, 2007, 106.

${ }^{141}$ Miura, 1989, 157-158.

${ }^{142}$ Shigematsu, 2006, 128 and 130.
} 
Another book, Fusōryakki (扶桑略記 Abbreviated History of Japan), which is estimated to have been written after $1094 \mathrm{CE}$, also contains two versions of the Urashima stories, but there are no titles or author names recorded. However, the first version of the Urashima story looks like a revised, modified, and embellished version of Tango no Kuni Fudoki Itsubun, and it also contains the essence of "Zoku Urashimako Denki" with the "Urashimako Den" in Kojidan storyline at the end of the story. The second version of the Urashima story is almost the same as "Urashimako Den" in Kojidan, and there are only a few minor differences.

In order to compare, contrast and analyse the chronological lineage of the Urashima story, the present analysis will follow the putative order of the completion of the stories, rather than the time of publication of the extant texts.

In short, there are two different sets of Heian period texts with different versions of the Urashima story: "Urashimako Den” and "Zoku Urashimako Denki” in Gunshoruiju, and two unknown titles of the Urashima story that have similar respective systematic structures and storylines in Fusōryakki.

Another important point to consider in the Heian historical overview is that there were already at least four different Urashima versions in existence at that time, and the authors of the Urashima stories in the Heian Period were no doubt able to access earlier written versions. The authors in the Heian Period were also able to copy the entire story from previous versions, or embellish the protagonists, so there are significant differences among the various Urashima stories of the Heian Period, as well as between them and the previous Asuka, Nara and earlier Heian Period versions.

\section{Source No.5: “Urashimako Den” (?-820?), Gunshoruijū 群書類従 (1819)}

Source: Shigematsu, Akihisa (ed.). "Urashimako Den”. Tokyo: Gendai Shichō Shinsha, 2006, pp. 40-43. ([Gunshoruijū ] Vol.135. Kokkai Toshokan Zōhon Ichibu Kaitei).

Appendix 1: Number 5, pp. 127-129. 


\section{Source No.6: “Zoku Urashimako Denki” (920? 932?), Gunshoruijū 群書類従}

\section{(1819)}

Source: Shigematsu, Akihisa (ed.). "Urashimako Den”. Tokyo: Gendai Shichō Shinsha, 2006, pp. 47-65. ([Gunshoruijū ] Vol.135. Kokkai Toshokan Zōhon Ichibu Kaitei).

Appendix 1: Number 6, not provided due to the length of the text.

Gunshoruijū (群書類従 Collection of Old Japanese Books) is an anthology series of ancient stories that was compiled in the late Edo Period (1603-1867) ${ }^{143}$ by Hanawa Hokiichi (塙保已一 1746-1821), who first started to work on the compilation in 1779 CE; and with some support from Nakayama Nobuna (中山信名 late Edo Perido) and Yashiro Hirokata (屋代弘賢 1758-1841) et al, he then published five hundred and thirty volumes in $1819 .{ }^{144}$

This series contains "Urashimako Den” and "Zoku Urashimako Denki." The former is believed to have been written not before the early ninth century, while the latter was believed to have been recorded in $920 \mathrm{CE}$ and $932 \mathrm{CE}$. However, this record of the year is dubious in several respects. It is very difficult to identify exactly what year "Urashimako Den" was written because the year is not mentioned in either "Urashimako Den" itself or in Gunshoruijū. However, generally speaking, "Urashimako Den" in Gunshoruijū is thought to date from the early ninth century. ${ }^{145}$ In addition, it is believed that “Zoku Urashimako Denki (続浦島子伝記)” was recorded in 920 CE and 932 CE, after “Urashimako Den”. Because of the meaning of Zoku (続), "to continue, to follow and to ensue," 146 this clearly indicates that this Urashima version was written after "Urashimako Den". So "Urashimako Den" will be examined here first, and for this reason "Zoku Urashimako Denki" is listed after "Urashimako Den" in Table 1 (see pp. 101-108) as well.

\footnotetext{
${ }^{143}$ Shinmura, 1993, 285.

${ }^{144}$ Momose, 2013, Gunshoruijū.

145 Shigematsu, 2006, 138.

${ }^{146}$ Morohashi, 1971. Vol.8 1205. See also Halpern, 1990,621.
} 


\section{Source No. 7 and 8: First and second Urashima story, Fusōryakki 扶桑略記 (post \\ 1094)}

Cited in: $7^{\text {th }}$ Month in Year 22 of The reign of King Yūryaku, Fusōryakki (Shintei zōho kokushi taikei). Tokyo: Yoshikawa Kōbunkan, 1942, pp.18-19.

Takioto, Noriyuki. “浦島子伝承の変容 Urashimako denshō no henyō. [The Transformation of a Folktale called Urashimashi]." The Journal of the Historical Association of Komazawa University 56, 2000, pp. 1-37.

Appendix 1: Number 7, pp. 130-131.

Appendix 1: Number 8, pp. 131-134.

Fusōryakki is a chronological history of Japan, originally in thirty volumes ${ }^{147}$ written in a classical Chinese style that contains stories from the first Emperor (Jimmu) to the Emperor Horikawa (堀河天皇 1086-1107 CE). ${ }^{148}$ Takioto (2000) explains that the editor Ajari Kōen (阿闍梨皇円 1073-1169 CE) ${ }^{149}$ was an erudite monk of the Pure Land sect who compiled Fusōryakki by the late twelfth century focused on Buddhist related issues. ${ }^{150}$ The book ends in $1094 \mathrm{CE}$ with the reign of Emperor Horikawa, so it is certain that Fusōryakki was compiled after that. ${ }^{151}$ It is considered that Fusōryakki is very important material for gleaning how the Urashima folklore was understood in the late Heian Period. ${ }^{152}$ There are two versions of the Urashimako story in Fusōryakki; however, their dates of compilation were not recorded.

\footnotetext{
${ }^{147}$ Of which only sixteen are exant. Digital Daijisen, "Fusōryakki", kotobank, 2014. <http://kotobank.jp/word/\%E6\%89\%B6\%E6\%A1\%91\%E7\%95\%A5\%E8\%A8\%98?dic=daijisen\&o $\mathrm{id}=16119000>$. Accessed on $18^{\text {th }}$ Feb, 2014.

${ }^{148}$ Digital Daijisen, "Emperor Horikawa”, kotobank, 2014. <http://kotobank.jp/word/\%E5\%A0\%80\%E6\%B2\%B3\%E5\%A4\%A9\%E7\%9A\%87>. Accessed on $18^{\text {th }}$ Feb, 2014.

149 The Rengein Tanjōji Temple, "The history of the Rengein Tanjōji Temple”, 2014. <http://www.rengein.jp/about/english.php>. Accessed on 18th Feb, 2014.

150 Takioto, 2000, 14-15.

${ }^{151}$ Oboroya, "Fusōryakki”, Nihon Daihyakka Zenshū. <http://100.yahoo.co.jp/detail/\%E6\%89\%B6\%E6\%A1\%91\%E7\%95\%A5\%E8\%A8\%98/>. Accessed on $15^{\text {th }}$ Oct, 2013.

152 Takioto, 2000, 14-15.
} 


\section{Comparison of motifs 1: A beautiful woman in both "Urashimako Den" in Kojidan and Gunshoruijū}

Some scholars, including Miura Sukeyuki (Japanese literary scholar, 1946- ) and Mifune Takayuki (historian, 1959- ) believe that "Urashimako Den" in Kojidan (12121215 CE) was recorded after the Fusōryakki version (post 1094) of the Urashima story, and after "Urashimako Den" (?-820?) and "Zoku Urashimako Denki" (920? 932?) in Gunshoruijü because of their compilation date. So, when comparing "Urashimako Den" in Kojidan and Gunshoruijū, it is clear that Gunshoruijū relies on the Kojidan version on the whole, and most expressions entirely match in the two versions. ${ }^{153}$ However, there are a few differences between them. The expression for the woman in the Urashima stories is one of them, and it can be analysed in two patterns: a metaphoric expression using a personal name or simply an adverbial and adjectival expression.

As can be seen in Table 1 (see pp. 101-108), the putative earliest extant version of the Urashima story of "Urashimako Den" in Kojidan uses Nani and Seishi to describe how beautiful the woman is. However, "Urashimako Den" in the Gunshoruiju version uses Yōhi and Seishi, and Yōhi only appears once in the fifteen versions of the Urashima story. Yōhi is also known as Yōkihi (楊貴妃) in Japan, as a metaphoric expression for the beauty of women. However, Yōhi was born in $719 \mathrm{CE}$ and died in $756 \mathrm{CE}$, so the aforementioned putative author of "Urashimako Den" in Kojidan, Iyobe no Umakai no Muraji, who is thought to have died around $702 \mathrm{CE}$, would not have known of her. ${ }^{154}$ Therefore, this "Urashimako Den" in Gunshoruijū could not have been recorded by Iyobe even though it has the same title of "Urashimako Den".

In addition, Yōhi became an iconic woman of beauty because of the book called Bai shi wen ji (Collection of Poems by Bai, 白氏文集 J: Hakushimonjū $)^{155}$ that first entered Japan in $838 \mathrm{CE}$ and describes her beauty. Yōhi also appears in Japanese literature in Genji Monogatari (源氏物語 Tale of Genji) ${ }^{156}$ in 1007 CE. ${ }^{157}$ Therefore,

\footnotetext{
${ }^{153}$ Shigematsu, 2006. 130.

${ }^{154}$ Shigematsu, 2006, 142-144.

${ }^{155}$ Hakushimonjū is a collection of poems by Bai Juyi (白居易 772-846CE), a Chinese poet. Daijirin, "Hakushimonjū", 2006, kotobank. <http://kotobank.jp/word/\%E7\%99\%BD\%E6\%B0\%8F\%E6\%96\%87\%E9\%9B\%86?dic=daijirin\&oi d=DJR_hakusimonnjuu_-010>. Accessed on 13 ${ }^{\text {th }}$ Jan, 2014.

156 Around 1004 CE the court lady Murasaki Shikibu wrote Genji Monogatari, which is sometimes referred to as the world's first novel. Henshall, 2004, 27.

${ }^{157}$ Shigematsu, 2006, 127-128.
} 
Yōhi appears to have become popularised in the Heian Period (794-1185 CE). In short, the pair of beauties known as Yōhi and Seishi in "Urashimako Den" in Gunshoruijū could not have been recorded earlier than $838 \mathrm{CE}$.

It is also noteworthy in terms of vocabulary, as Shigematsu (2006) mentions, that whereas the phrase 百和香 (“the very beautiful perfume”) in Kojidan is correct usage in Chinese, the phrase 百花香 in Gunshoruijū does not make sense. It appears to be a copyist's error based on the Kojidan version. This is also further evidence that the Kojidan version of "Urashimako Den" predates the Gunshoruijū version. ${ }^{158}$

\section{Comparison of motifs 2: "Urashimako Den" and "Zoku Urashimako Denki" in Gunshoruijü}

The exact year of completion of "Zoku Urashimako Denki" in Gunshoruijū is not identified, although it is recorded as the year $932 \mathrm{CE}$ in the middle of the story and the year 920 at the end. However, there are several questionable points in terms of the time of completion of "Zoku Urashimako Denki". ${ }^{159}$ The "Zoku Urashimako Denki" storyline is so similar to "Urashimako Den" in Gunshoruijū that it was deemed that a translation of "Zoku Urashimako Denki" is superfluous, and is thus not provided in Appendix 1: Translation, due to its length and degree of similarity.

If the "Urashimako Den" is called version A, "Zoku Urashimako Denki" is a mixture of an embellished version of A and classical Chinese poems in the style of “seven words and twenty-two rhymes (七言二十二韻)” (here called B). Shigematsu (2006) mentions that eminent literary scholars Yamagishi Tokuhei (山岸徳平 Japanese literary scholar, 1893-1987), Mizuno Yū (水野祐 historian, 1918-2000) and Ichiko Teiji (市古貞次 Japanese literary scholar, 1911-2004) all regarded “Zoku Urashimako Denki" as merely a version of "Urashimako Den" embellished with classical Chinese poems of seven words and twenty-two rhymes, and Mizuno in particular claims that this classical Chinese part of poems is itself "Zoku Urashimako Denki". ${ }^{160}$ This is another

\footnotetext{
${ }^{158}$ Shigematsu, 2006, 130.

${ }^{159}$ Shigematsu, 2006, 132.

${ }^{160}$ Shigematsu, 2006, 132-134.
} 
reason which clarifies that "Urashimako Den" was recorded first, and "Zoku Urashimako Denki" later.

It is recorded at the beginning of the "Zoku Urashimako Denki", "This is written at the Appointments Changeover Office ${ }^{161}$ on $22^{\text {nd }}$ April in the year of Jöhei 2 (ca. year 932 CE). Sakanoue no Ie no Takaakira wrote it”. Not much is known about Sakanoue no Ie no Takaakira, but he was one of the Central Bureau staff and had academic skills, so it is surmised that he added very complicated embellishment to the story, perhaps when he was off duty. ${ }^{162}$ It goes without saying that he was able to access previous recorded versions, particularly "Urashimako Den"; so as can be seen in Appendix 1 (see pp. 127-129), the two versions of the Urashima story in Gunshoruiju are very similar, and it is also similar to the Kojidan version of "Urashimako Den" which has a very similar storyline and expressions.

\section{Comparison of motifs 3: The first Urashima story in Fusōryakki}

There are two versions of the Urashima story in Fusōryakki; however, it is noteworthy that the first story does not contain any account of Shimako after returning to his hometown. ${ }^{163}$ It may be deduced that the author of this first Urashima story in Fusōryakki copied the ending from "Urashimako Den" in Kojidan.

Significant similarities can be seen in the characters of the constellations Hyades and Pleiades that only appear in Tango no Kuni Fudoki Itsubun and this first Fusōryakki version among the fifteen Urashima stories. Shigematsu (2006) argues that this first Urashima story in Fusōryakki is a significantly modified version of the Tango no Kuni Fudoki Itsubun version, and it is plausible that the storylines that Ajari Kōen quoted relied on the story from "Zoku Urashimako Denki” in Gunshoruijü. ${ }^{164}$ Needless to say, there were already several versions of the Urashima story available by $1094 \mathrm{CE}$, the year of compilation of Fusōryakki. This first Urashima story appears to have been systematically developed from "Urashimako Den” in Kojidan, Tango no Kuni Fudoki

\footnotetext{
${ }^{161}$ Kageyu no sōkyoku (勘解由の曹局) was the office where documents were finally handed over from predecessor to successor upon change of personnel.

162 Shigematsu, 2006, 134-135.

163 Takioto, 2000, 16.

${ }^{164}$ Shigematsu, 2006, 131.
} 
Itsubun, and "Zoku Urashimako Denki" in Gunshoruijū, and not only contains a mixture of lineages but also some entirely new developments.

\section{Comparison of motifs 4: The second Urashima story in Fusōryakki (almost identical version to "Urashimako Den" in Kojidan)}

The second version of the Urashima story in Fusōryakki almost completely matches the second part of "Urashimako Den" in Kojidan, including the usage of Chinese characters and the expressions used, and likewise, it does not mention Urashima's return. Only six differences in regard to the vocabulary and expressions used can be seen between this second Urashima story in Fusōryakki and "Urashimako Den" in Kojidan. What is more, one of the differences in this second story is " $a$ beautiful garden lantern lights the silver floor, and it adds beauty to the brocade carpet” (蘭燈照銀床。而錦筵加彩), 一which does not appear in “Urashimako Den” in Kojidan, but which is exactly the same as a sentence in "Zoku Urashimako Denki" in Gunshoruijū. Therefore, the second Urashima story in Fusōryakki is regarded as identical to the version of "Urashimako Den" in Kojidan, which also quotes expressions from "Zoku Urashimako Denki" in Gunshoruijü. This is another variant of the hybrid version that follows the lineage from previous versions of the Urashima story. 
Comparison of motifs 5: A diagram of the linear development of the Urashima story from putative oral versions to the Heian Period.

Diagram 1. The development of the Urashima story from putative oral version to the Heian Period.

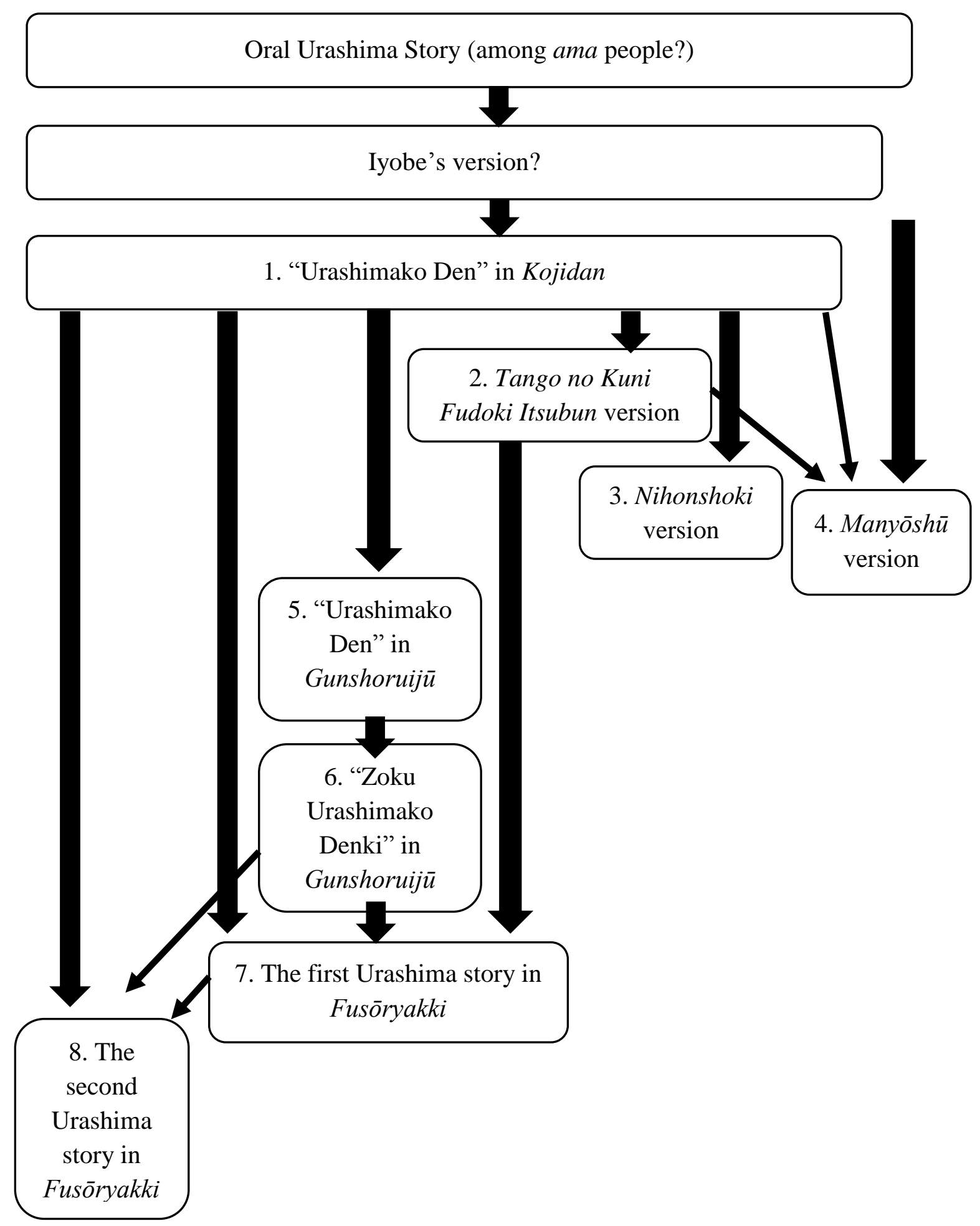


As can be seen in Diagram 1, it may be surmised that the oral Urashima story was passed down among ama groups of people from China from the distant past and it was probably a well-known tale in some parts of Japan long before it was recorded in writing. Based on this oral tale, a recorded version of the Urashima story appeared, the earliest putatively being the source material of the version recorded in "Urashimako Den", that appears in Kojidan. However, through the Asuka, Nara and Heian Periods, i.e. the late seventh to late twelfth centuries, various Urashima versions appeared, but some are alike and others have variation to the storyline or different characters compared to others. In addition, each Urashima story seems to have a different purpose and meaning, so an interpretation of the Urashima story may be differ between each of these recorded versions.

By the time of the Urashima story in the Heian Period, the way the Urashima story had developed had been clearly influenced by previous recorded versions. However, due to the similarity of names in the Urashima story, unreliability of dates recorded, and the books such as Gunshoruijū and Fusōryakki containing much earlier versions of the Urashima story than their years of publication, the situation is complicated and it is not easy to trace the development. The diagram here provides clear explanation and analysis of the development in separate lineages, and how each Urashima story developed from the oral version to the recorded Heian Period version.

1) Broadly speaking, the source material on which "Urashimako Den" in Kojidan was based is putatively the earliest recorded version of the Urashima story because of its vocabulary and storyline, although Kojidan was believed to be compiled after $1094 \mathrm{CE}$. The putative author was Iyobe no Umakai no Muraji. Also "Urashimako Den" is regarded as the source of the Urashima story for the following several versions.

2) Tango no Kuni Fudoki Itsubun version is a developed and embellished version of the Kojidan source material, because it says that "The following story is consistent with what Mr Iyobe no Umakai no Muraji, a former provincial governor, recorded". However, there is no evidence as to who the scribe was, but it mentions Iyobe's name as the source of the story. 
3) Nihonshoki is a very short and brief version of the Urashima story due to its purpose. It is written in an idiosyncratic classical Chinese style, and was the official governmental historiography representing the new nation-state of Japan to foreign countries, meaning those of China and Korea, ${ }^{165}$ and it is closer to "Urashimako Den" in Kojidan and the Tango no Kuni Fudoki Itsubun version, rather than Manyōshū.

4) The Manyōsh $\bar{u}$ version of the Urashima tale as a narrative poem is very different from the aforementioned versions. It unequivocally specifies the author as Takahashi no Mushimaro, and the Urashima narrative poem is from the "Mushimaro Collection", Urashima of Mizunoe. ${ }^{166}$ And it is hard to identify whether this Urashima narrative poem is derived from previous versions or not because the storyline and characters are quite different. Therefore, it is feasible that Takahashi no Mushimaro would have been able to compose the Urashima narrative poem in Manyōshū with reference to "Urashimako Den", Tango no Kuni Fudoki Itsubun (post 713 CE) and Nihonshoki (720 CE) as source materials. It is also likely that the oral Urashima story was very popular and well known at that time. This poem in Manyōsh $\bar{u}$ therefore may have been based on multiple sources. Takahashi did not merely compose in imitation of earlier versions, but he chose to present a very beautiful romanticised version of the Urashima tale as a narrative poem. It does not appears to be in a direct lineage from the other Urashima versions, so it is regarded as an independent Urashima story as a narrative poem.

5) "Urashimako Den" in Gunshoruijū relies on the Kojidan version on the whole, and most expressions are entirely identical in the two versions. ${ }^{167}$ Also due to the age of vocabulary (based on Yōhi) and a copyist's error in Chinese writing, this version could not have been recorded earlier than "Urashimako Den" in Kojidan.

6) "Zoku Urashimako Denki" in Gunshoruijū is a mixture of an embellished version of "Urashimako Den" in Gunshoruijū (here called A) and classical Chinese poems in the style of “seven words and twenty-two rhymes (七言二十二韻)" (here called B), therefore A + B = "Zoku Urashimako Denki". Neither "Urashimako Den"

165 Tada, 2008, 14-15.

166 Keene, 1969, 214-215.

${ }^{167}$ Shigematsu, 2006. 130. 
nor "Zoku Urashimako Den" in Gunshoruijū appears to have been influenced by the Tango no Fudoki Itsubun version of the Urashima story.

7) The first Urashima story in Fusōryakki is very similar to the second half of "Urashimako Den" in Kojidan from the beginning of the story to Urashima's return, but it does not relate events after his return. The constellations of Hyades and Pleiades appear in this story, which are only seen in the Tango no Kuni Fudoki Itsubun version, and it is a significantly modified version of Tango no Kuni Fudoki Itsubun, at that. It is plausible that the storyline quoted by Ajari Kōen relied on "Zoku Urashimako Denki” in Gunshoruijū ${ }^{168}$ Therefore, the first Urashima story in Fusōryakki may be regarded as a very embellished version of the Tango no Kuni Fudoki Itsubun tale, combined with the versions in "Urashimako Den" in Kojidan, and "Zoku Urashimako Denki".

8) The second Urashima story in Fusōryakki is almost identical to "Urashimako Den" in Kojidan, and only several quotations from "Zoku Urashimako Denki" and the style were influenced by the first Urashima story in Fusōryakki.

\section{Conclusion of Part Two}

The lineage of the recorded versions of the Urashima story and its interpretations from the Asuka Period (593-710 CE) to the Heian Period (794-1185 CE) were examined and identified, based on a historical overview, the sources, and comparison of motifs referenced in Table 1 and Appendix 1. Also Diagram 1 was provided in order to clarify the evolution of the lineages and how the Urashima story changed over time. One of the difficulties and complexities that arises, is that the time of composition and the compilation of the recorded texts of the various versions reveal some inconsistencies. The way in which each Urashima version was influenced by other recorded versions over time was analysed, and it was found that the putative earliest recorded version of the Urashima story may be estimated as much earlier than the rest. Focusing on the vocabulary and its usage, scholars can date the text, and by this method the putative earliest recorded version of the Urashima story was identified as "Urashimako Den" in Kojidan (or its source material), which is believed to have been published after 1094. Gunshoruijū was compiled in 1819, but is very similar to Kojidan,

${ }^{168}$ Shigematsu, 2006, 131. 
so it is necessary to analyse their respective vocabularies. In addition, the same Urashima story title can be found in different versions, which also complicates matters due to the time difference between the composition of the text and its publication, but Diagram 1 provides a clear lineage and outlines the influences between stories.

As can be seen in Diagram 1, it is estimated that the oral Urashima story was a well-known tale before it was recorded in writing, because a prototype of the Urashima story probably originated near Lake Dongting (洞庭湖 $\mathrm{J}$ : dotteiko) in China and was most likely transmitted to Japan via the ama group of people, dwellers of coastal areas in Japan. The Hakuhō Period (654-710 CE) created a powerful new culture, which included the commencement of the compilation of Nihonshoki (720 CE) and Kojiki (712 CE), the appearance of Manyōshu poets, and the flourishing of Buddhist art. The Urashima story appears to have been first recorded in writing during this period, probably by the author Iyobe no Umakai no Muraji. This (now lost) text seems to have been the basis of the version "Urashimako Den" in the Kojidan anthology published in 1212-1215 CE. What is more, this version is influenced by Chinese ideology and Daoism (such as Mt. Hōrai), and the text is thought to be possibly even older than the Nara Period (710-784 CE), so that it is regarded here as the putative earliest recorded version of the Urashima story. 


\section{PART THREE}

\section{Analysis, from the Muromachi Period $\left(1392-1573\right.$ CE) ${ }^{169}$ to the Shōwa Period (1926-1989 CE). ${ }^{170}$}

\section{CHAPTER 5: Muromachi Period (1392-1573 CE)}

The Urashima story first appears in book form, a picture book (絵本 ehon), rather than as a story in a large collection, in the Edo Period (1603-1867 CE), but it is believed that the Urashima story text was recorded in the Muromachi Period (13921573 CE) in the narrative genre commonly known as Otogizōshi (御伽草子 The Fairy Tale Book) that was popular in the late Muromachi to early Edo Periods. The Urashima story published in the Edo Period gains a new title, Urashima Tarō, but the storylines and characters are quite different and greatly embellished compared to the previous recorded versions.

What is more, it is not certain that the Urashima story in Otogizōshi is derived from previous recorded versions due to the dynamic development of the story. The Muromachi Period saw a huge cultural shift including the rise of Buddhism and a shift in the target audience from the aristocracy, politicians, monks and the educated of the élite, to the general period. As a result the quality of literature deteriorated compared to the Heian Period (794-1185 CE).

Therefore, Urashima Tarō may be derived from all previous recorded versions of the Urashima story, and was modified due to the great cultural growth in the Muromachi Period.

\section{Historical overview: Muromachi period (1392-1573 CE)}

Varley (1973) states that the Muromachi Period is also known in history as the Ashikaga Period or Muromachi Shogunate (1336-1573 CE), and was a tumultuous age in Japanese history characterised by fighting and wars, meaning that relatively little

\footnotetext{
${ }^{169}$ Shimmura, 1993, 2506.

${ }^{170}$ Shimmura, 1993, 1289.
} 
literature was produced. ${ }^{171}$ Nevertheless, there was the flourishing of Zen Buddhism and associated cultural achievements of $n \bar{o}$ (能 “talent” or “ability”), “monkey music" (猿楽 sarugaku) and “field music” (田楽 dengaku), and kyōgen (狂言 mad words) in theatre, linked verse (連歌 renga) ${ }^{172}$, tea ceremony (茶の湯 cha no yu), rock gardens, and monochrome painting including Zen abbots, folk deities, and flowers and birds as their chief subject matter. ${ }^{173}$

\section{Source No. 9: “Urashima Tarō”, Otogizōshi (1716-1736)}

Cited in: Ōshima, Tatehiko (annot. and trans.), Otogizōshi. Nihon Koten Bungaku Zenshū, vol. 36, Otogizōshi sh̄̄. Tokyo: Shōgakukan, 1974, pp. 414-424.

Appendix 1: Number 9, pp. 134-138.

Otogizōshi refers broadly to a literary genre, and more narrowly to a particular anthology. ${ }^{174}$ Araki (1981) explains that myths, legends, folklore, religious beliefs, and quasi-historical facts are the vital ingredients of Otogizōshi, a Japanese literary genre of some four hundred short fictional narratives that were written primarily in the fifteenth and sixteenth centuries. What we presume to be its genesis might be typified by the way in which many works in this genre originated in history or legend, evolved in the oral tradition, and arrived at their ultimate written form. ${ }^{175}$

While of considerable historical interest, the short stories of the fifteenth and sixteenth centuries, including in the Azuchi-Momoyama Period (安土桃山 15731598/1600 CE), ${ }^{176}$ commonly became known as otogi-zōshi, but they cannot be said to possess high literary value. Some look back to the world of the Heian Court; others contain folk materials or elements of the miraculous that may have been included to

\footnotetext{
171 Varley, 1973, 76-78, and 94.

172 The idea of two or more people alternately (or consecutively) composing the 5-7-5 and 7-7 syllable links of a tanka. Varley, 1973, 85.

${ }^{173}$ Varley, 1973, 79-90.

${ }^{174}$ Shimauchi, 1991, 1. See also Someya, 2004, 62.

175 Araki, 1981, 1.

${ }^{176}$ Shimmura, 1993, 55.
} 
interest barely literate readers. Promising stories are sometimes ruined by absurdities before their course is run, but even the less successful stories provide valuable glimpses of a society that, though afflicted by warfare, enjoyed the possibility of welcome change. The stories are anonymous, but the authors seem to have been both courtiers and Buddhist priests. ${ }^{177}$

The Urashima story spread and became a well-known story in the Muromachi Period to Edo Period among common people by means of the spread of woodblock printing, which enabled wider access to the story through mass production of books. Woodblock printing in the Edo Period will be explained later (see pp. 66-67).

Otogizōshi, an anthology in twenty-three volumes published by Shibukawa Kiyouemon (渋川清右衛門 date unknown) in Ōsaka in the Kyōho Period (享保 1716$1736 \mathrm{CE})$ containing fantasy and moral folklore stories. ${ }^{178}$ The Urashima story is one of the books in Otogizōshi, titled Urashima Tarō. Miura (1989) also notes that Otogizōshi is in the kana prose-style writing of mature literature. The oldest extant of these books is a picture book produced in the mid-Muromachi period, and the other is a Nara Ehon $^{179}$ at the end of the Muromachi Period. These books are centred around beautiful coloured pictures, but the story itself is not described in detail. ${ }^{180}$

\section{Comparison of motifs 1: The book title and the character name of Urashima Tarō}

As can be seen in Table 1 (see pp. 101-108), the name of the book and the main character both appear as Urashima Tarō. Urashima is presented as the family name, and is clearly derived from all of the previous recorded versions. However, the main character's name changed in this period to Urashima for the family name and Tarō as

\footnotetext{
${ }^{177}$ Encyclopædia Britannica online, “Japanese literature”, 2013. <http://www.britannica.com/EBchecked/topic/301194/Japanese-literature/61857/The-Muromachi1338-1573-and-Azuchi-Momoyama-1574-1600-periods?anchor=ref319902>. Accessed on $16^{\text {th }}$ Jan, 2014.

${ }^{178}$ Digital Daijisen, “Otogizōshi”, Kotobank, 2013. <http://kotobank.jp/word/\%E5\%BE\%A1\%E4\%BC\%BD\%E8\%8D\%89\%E5\%AD\%90?dic=daijise n\&oid=02452500>. Accessed on $13^{\text {th }}$ Jan, 2014.

${ }^{179}$ Nara Ehon (奈良絵本) is one of a group of books that was published from the late Muromachi to the mid Edo Period. The reason for the name of Nara is unknown. Otogizōshi was one of the main collections of Nara Ehon. Sekai Daihyakka Jiten, "Nara Ehon", kotobank, 2013. <http://kotobank.jp/word/\%E5\%A5\%88\%E8\%89\%AF\%E7\%B5\%B5\%E6\%9C\%AC?dic=daijisen \&oid $=13862400>$. Accessed on $23^{\text {rd }}$ Apr, 2014.

${ }^{180}$ Miura, 1989, 165. See also Mifune, 2009, 94.
} 
the given name. This is the origin of the present-day orthodoxy of this character name, and it influenced all subsequent versions of the Urashima story.

The previously common main character names of Mizunoe no Ura no Shimako and Mizunoe no Ura Shimako, a combination of the place names and location names, changed into simply Urashima because of the usage of the particle "no". Also a given name for the character is established for the first time as Tarō, meaning first son in the family, a typical traditional Japanese boy's name, from being an unidentified fisherman called Shimako ("island boy"). Mifune (2009) states the contradiction that Urashima Tarō, rather than Urashimako, first appears in Otogizōshi, and the first appearance of his name as Urashima Tarō is in Hizōsho (秘蔵書 Treasured Book) in 1438 CE, but the Urashima story outline in Hizōsho differs little from the Otogizōshi Urashima story. ${ }^{181}$ The author and the compilation year of the story of Urashima Tarō are not recorded, so it is impossible to say which one of them was recorded earlier, but, either way, the name Urashima Tarō originated in the Muromachi Period. Needless to say, this affects the following versions of the Urashima story in Table 1 (see pp. 101-108) after the Muromachi Period.

\section{Comparison of motifs 2: The Sea Palace (ryügūjō 竜宮城)}

A new location name appears in Otogizōshi: The Sea Palace (ryūgūjō 竜宮城), instead of Mt. Hōrai, the mountain of immortality and Tokoyo, everlasting world and night. $R y \bar{u}$ (竜) means 'a dragon', and is also one of the Four Benevolent Animals, ${ }^{182}$ $g \bar{u}$ (宮) means 'a palace', and $j \bar{o}$ (城) means 'a castle', so it is translated as the Sea Palace, the Sea King's Palace or the Sea Dragon King's Palace. The Chinese dragon is normally a good-natured and benign creature: a symbol of natural male vigour and fertility. One of the creatures of the four directions in the world, the dragon stands in the East, the region of sunrise, of fertility, of spring rains and of rain in general, and in this guise, he is known as the 'azure dragon' and is contrasted with the 'white tiger', the ruler of the West and of death. ${ }^{183}$

According to Eberhard (1986), at an early date, cosmological speculation distinguished four kinds of dragon: first of all there are the heaven-dragons, symbolising

${ }^{181}$ Mifune, 2009, 95.

${ }^{182}$ Morohashi, 1971, vol.12, 1112.

${ }^{183}$ Eberhard, 1986, 83. 
the regenerative power of heaven; then the spirit-dragons, which cause the rain to fall; thirdly, earth-dragons, which rule over springs and water courses; and finally the dragons which guard treasure. In addition, people believed in four dragon-kings, each of which ruled over one of the four seas that encompass the earth, and these 'seadragons' play a particularly big part in popular tradition. The sea-dragon king, it was believed, dwelt in a splendid palace full of the most beautiful and valuable things, and those on whom fortune smiles may visit him at the bottom of the sea- they may even be rewarded with one of his daughters in marriage! ${ }^{184}$

Therefore, the reason why Urashima Tarō and the woman go to the Sea Palace in the Otogizōshi version is obviously based on this early Chinese cosmological concept, rather than for seeking immortality or the everlasting world as in earlier versions.

However, the Sea Palace is not described as under the sea yet, rather, it is an island that takes ten days to arrive at by boat, so this expression is similar to Tokoyo no kuni, which does not indicate a specific country but is in a far distant place in any direction, from which there is no return. ${ }^{185}$ So Urashima Tarō in Otogizōshi still retains a mixture of Chinese ideology and the three-tiered Japanese vertical view of the cosmos.

\section{Comparison of motifs 3: Marriage in return for a rescue}

It is noteworthy that the time of separation comes at the end of the story eventually, and the woman confesses that she is the turtle formerly rescued by Urashima. On returning to her home, the Sea Palace, she was to marry Urashima Tarō in return for the rescue. This aspect of marriage is quite different from the previous versions of the Urashima story. The woman in Otogizōshi is described as very soft and mild, also she looks very uncertain and fears going home by herself, as if she needs Urashima Tarō to come along with her all the time, otherwise she cannot do much by herself. So Urashima Tarō decides to stay at the Sea Palace, and as she begs him to marry her, he does as she wishes. By contrast, the woman in previous versions was described as a very strong, confident and demanding character, because the woman forces Shimako to take her home and to get married, and there are is no sense of appreciation for him rescuing her at all. It seems more as though the woman was looking for a husband and she simply carries out this plan. However, the marriage

\footnotetext{
${ }^{184}$ Eberhard, 1986, 84.

185 Shimode, 1968, 112-113 and 164-165.
} 
between the woman and Urashima Tarō in the Otogizōshi version appears very different, because the woman wants to marry Urashima Tarō in return for her rescue. This is another development of the Urashima story, because although the story outline is still broadly similar, the meaning of their marriage is a completely new concept and presents a new interpretation of the Urashima Tarō story in the Muromachi Period.

\section{Comparison of motifs 4: Four seasons}

Although the expression of spring and autumn can be seen in previous recorded versions of the Urashima story, detailed description of the four seasons appears for the first time in Urashima Tarō. The four seasons are described as paired with the four directions for the first time: East is the direction of Spring, South is for Summer, West is for Autumn, and North is Winter. The relationship between the four seasons and four directions symbolises the timeless space of the world where Urashima Tarō was invited by the woman. The author of Urashima Tarō uses this beautiful expression of timeless space in the world, instead of their drinking a golden elixir or medicine to gain longevity. In addition, the expressions of the seasons seem very poetic and extravagantly embellished using the beauty of nature depicted through flowers, birds, the wind and scenery. Miura (1989) observes that the beauty of nature frequently appears in $\mathrm{waka}^{186}$ expressions in the Heian Period by means of indicating a typical object of the seasons. ${ }^{187}$ This motif still transmits the previous recorded storyline of the Urashima story, but it greatly emphasises a 'Japanese' flavour of expression. Mifune (2009) describes this situation as evoking a great deal of 'Japanese' atmosphere. ${ }^{188}$

Ordinarily the four seasons indicate to Japanese people the changing of time, and usually also give a feeling of the passing of time too. However, Urashima Tarō experiences the four seasons repeatedly in rapid succession at the Sea Palace as if they appear and disappear all at once. Therefore, this new expression of the four seasons and four directions correlates with Mt. Hōrai, the Mountain of Immortality, and Tokoyo, everlasting world or night in previous versions.

\footnotetext{
${ }^{186}$ A traditional Japanese poem of thirty-one syllable. Shimmura, 1993, 2748.

${ }^{187}$ Miura, 1989, 175.

${ }^{188}$ Mifune, 2009, 98.
} 


\section{Comparison of motifs 5: The wasteland}

The characters of creatures such as the dragon, tiger, turtle, and birds, appear to be related to some ideology or mythical beliefs related to the Four Symbols (Shijin or Shishin 四神) in ancient Chinese belief. The Four Symbols are derived from ancient Chinese belief in four mythical creatures in the Chinese constellations, each one of them representing a direction and a season: the Azure Dragon (seiry $\bar{u}$ 青竜) of the East represents Spring, the Vermilion Bird (suzaku 朱雀) of the South represents Summer, the White Tiger (byakko 白虎) of the West represents Autumn, and the Black Turtle (gembu 玄武) of the North represents Winter. ${ }^{189}$

A noteworthy new motif in the Otogizōshi version is that after Urashima Tarō returns to his hometown, it is described as torafusu nobe 虎ふす野辺 “a wasteland where the tiger lives". Also, as can be seen in Appendix 1 Translation (see pp. 134138), the expression 'even a tiger and a wolf, and a human has a destiny' appears. This symbolism of the tiger appears twice, so the introduction of the tiger motif surely has something significant to do with the story or characters. The aforementioned pair of the dragon (youth) and tiger (old age) in the comparison of motifs 2 provides some clue, with the dragon standing in the East, the region of sunrise, of fertility, of spring rains and of rain in general, in contrast to 'the White Tiger', the ruler of the West and of old age. ${ }^{190}$ So while the dragon represents Urashima's youth, the tiger relates to his old age.

Urashima Tarō does not die at the end of the Otogizōshi version, but this motif may imply the end of his life, close to his death. The tiger is a bearer of the male principle, and for this reason, a white tiger symbolised autumn and the West, and 'White tiger' is also a derogatory expression for a woman. ${ }^{191}$

So, Urashima Tarō in Otogizōshi contains several new hidden messages, meanings and witty expressions, and each of these characters has an intimate involvement in the storyline, which implies to the audience the great impact of literary

\footnotetext{
${ }^{189}$ Daijiri, "Shijin", kotobank, 2013. <http://kotobank.jp/word/\%E5\%9B\%9B\%E7\%A5\%9E?dic=daijisen\&oid=08002100>. Accessed on $18^{\text {th }}$ Jan, 2014. See also, Hitachi Solutions Business, Ltd., "Shishin", kotobank, 2010. <http://kotobank.jp/word/\%E5\%9B\%9B\%E7\%A5\%9E?dic=sekaidaihyakka\&oid=00187544 >. Accessed on $30^{\text {th }}$ April, 2014.

${ }^{190}$ Eberhard, 1986, 83.

${ }^{191}$ Eberhard, 1986, 291-292.
} 
evolution with a rich Japanese flavour combined with Chinese ideology that was developed considerably more than in the previously recorded Urashima stories. In short, the Sea Dragon King's Palace symbolises rejuvenation, while the references to tigers at Urashima's home imply his old age there.

\section{Comparison of motifs 6: The numbers three and seven (hundred years), and Buddhist influence}

Previously mentioned Urashima stories contain some Buddhist influences, but the Otogizōshi Urashima Tarō version contains a strong Buddhist influence, as various Buddhist terminologies, such as tashō no en (他生の縁, karma from a previous existence), nise no en (二世の縁 married couple’s destiny), raise (来世 afterlife), and eshajōri (会者定離 those who meet must part), appear due to the new cultural flourishing of the Muromachi Period. ${ }^{192}$

The number three was explained earlier. However, further understanding of the number three and its relationship with Buddhism will be examined here.

Morohashi (1971) states that 'three' contains the meaning of the way of Heaven, Earth and the Way, and that the group of you, father and master, also means east. ${ }^{193}$ Eberhard (1986) states that three is masculine (yang) and a very important number in Chinese thought: from the basic trinity of heaven, earth and man, and also Confucianism, Daoism, and Buddhism. Seen as the 'three teachings', these are syncretised in the expression 'The three teachings are one'. Buddhism particularly is a way of looking at death and at the meaning of life in general. ${ }^{194}$ This could be the reason why at the end of the story it says 'when he opens the box, three purple clouds puff out from inside and floated away.' (see Appendix 1 Translation pp. 134-138) 'Three lines' appears for the first time and could be a symbol or implication of the death of Urashima Tarō, with the combination of purple. ${ }^{195}$ Therefore, this is a lineage development from "Urashimako Den” in Kojidan, "Urashimako Den” and "Zoku Urashimako Denki” in both Gunshoruijū.

\footnotetext{
192 Ichiko, 2010, 162-165. See also Ōshima, 1974, 417-420.

${ }^{193}$ Morohashi, 1971, vol.1 107.

${ }^{194}$ Eberhard, 1986, 288-299.

195 See p37-38, Comparison of motifs 8: The colour Purple.
} 
According to Eberhard (1986), seven contains the meaning of the direction to the West. ${ }^{196} \mathrm{He}$ continues that seven is of particular significance in the cult of the dead, the term 'make seven' referring to the seven-day period of mourning following a death. ${ }^{197}$ Shonanoka (初七日), a (Buddhist) service held on the seventh day after a person's death, continues to be held in modern-day Japan, so the number seven is not just a random number of exaggeration, but is in fact related to Buddhism. The Muromachi period was one of great cultural growth, particularly under the influence of Zen Buddhism, so it is no coincidence that "seven hundred years" elapsed after Urashima Tarō's return, nor that mention of a period of seven hundred years appears for the first time in the Urashima story. Therefore, seven is symbolic of the end of Urashima's life.

\section{Comparison of motifs 7: The mysterious box, tamatebako and tamakushige}

As can be seen in Table 1 (see pp. 101-108), Urashima Tarō receives a souvenir box when he returns to his home land, which is one of the common characteristics in the Urashima storyline with the exception of Nihonshoki. Attention in the Otogizōshi version particularly draws to tama which has a double meaning: tama (魂, 嵬, 霊), the soul or spirit, and a homonym, 玉 “ball” and “jewel”). 198

It is noteworthy that the box is recorded as tamakushige (玉筴, 玉厘 a beautiful box for cosmetics) from the Asuka to Heian Period and is translated as a casket, a beautiful box or a token box in the Urashima story. Shimmura (1993) explains that tama (玉) means (1) a group of beautiful jewels, (2) particularly a pearl, (3) a beautiful object, important object, or praise word, and kushige (櫛笥) is a toolbox for cosmetics. Although the Chinese characters 筴 and 厘 are recorded, it means a box. ${ }^{199}$ However, the word tamatebako (玉手箱 a treasure box, a token box) appears for the first time in Urashima Tarō in Otogizōshi in the final tanka (traditional Japanese songs with 5-7-57-7 syllables ${ }^{200}$ when Urashima Tarō sings after he opens the box.

\footnotetext{
196 Morohashi, 1971, vol.1 81.

${ }^{197}$ Eberhard, 1986, 261-262.

198 Shimmura, 1993, 1611.

${ }^{199}$ Shimmura, 1993, 727.

${ }^{200}$ Shimmura, 1993, 1625.
} 
On the other hand, tamatebako includes the meaning of the first tama translation (玉); te (手) means a hand, and hako (箱) a box. But tebako (手箱) means a handy box that contains small tools, such as that which can be seen in Murasaki Shikibu Nikki (紫 式部日記 Murasaki Shikibu Diary). ${ }^{201}$ So the newly-appearing word tamatebako could be an evolutional development through literary influence as well as the literary development of the Heian and Muromachi Period, but is not in direct lineage from previous Urashima stories. Shimmura (1993) continues to explain tamatebako as: (1) the box given to Urashima by the Princess of the Sea Palace in Urashima folklore, (2) a very important box that has to be kept secret and its contents not readily opened or shown (meaning derived from explanation (1) in tamatebako). ${ }^{202}$

Therefore, the two meanings of tama can be interpreted as the author's play on words in the story using a witty expression of double entendre, as both an important jewel box and as a box for the soul or spirit. It is surmised that people in the Muromachi Period would have understood this technique of word play and enjoyed the Otogizōshi versions of the Urashima story. One might expect the beautiful souvenir box to contain tama, jewels, but instead it contains tama, the soul of Urashima Tarō. Arguably, the appearance of this play on words suggests that the public were still attuned to this thought association during and until the Muromachi Period. While it influenced later versions, the close connection between the two seems to have been lost thereafter.

Comparison of motifs 8: The significance of the white smoke from the box, through tanka (短歌): puns, double entendre, humour, real intention (true feelings) and obligation of honne (本音) and tatemae (建前), satire and lingering affection

Oral versions doubtlessly existed as tales and folklore long before the story was first written using kanji (漢字 Chinese characters), and later hiragana and katakana script when they were developed. Certainly, devices of orality played a significant role in the telling of tales and folklore, and these oral devices include songs and poems. Uta (歌 songs) and shi (詩 poems) were also recorded in writing, and tanka (短歌) ‘short

\footnotetext{
${ }^{201}$ Murasakishikibu Nikki is a diary written about 1008-1009 CE by Murasaki Shikibu. Shimmura, 1993, 2504 and 1769.

${ }^{202}$ Shimmura, 1993, 1613.
} 
verses' (5-7-5-7-7 syllables) can be seen in Manyōshū. These songs and poems, including tanka, are a product of the spoken word, and continued to reflect aspects of orality even after they were incorporated into the written style of language.

Palmer (2011) mentions that the composing of poetry was an art form that clearly predated extant written records: it appears to have developed as one genre of orally transmitted verbal art, comprising many sub-genres, of which many are identifiable in the Manyōsh $\bar{u}$ anthology. ${ }^{203}$ Palmer (2011) continues that the art of punning, which is a form of speech play, has long been one of the sources of humour in Japan, as is clear from the earliest extant written records. ${ }^{204}$

It may be hypothesised that the tanka (短歌), particularly the vocabulary of tama, in this Urashima Tarō version contains hidden meaning, and humorous and witty expressions, reflecting Muromachi period culture. At the end of the Urashima story a common description is of 'a white cloud' or 'purple cloud', and 'purple smoke' in general. Tama as in tamakushige, a beautiful box, also appears in previous recorded versions of the Urashima story, so that the combination of tamakushige and tamatebako (jewelled box), and the 'cloud and smoke' are actually related to each other, since the box is both a "jewelled" box (externally) and a "soul" box, containing his spirit internally, which emerges as a puff of smoke. This implies the end of life, which could be either the old age or death, of Urashima. Thus the souvenir that Urashima receives from the princess is his soul, his life, and it escapes from the beautiful box as smoke or cloud.

In particular, therefore, puns are used to identify and convey the true meaning of the clouds and smoke. As noted earlier, there is a tama, used for "jewel" and for important objects such as the souvenir box, and also for Urashima's soul which can be identified in the tanka. Throughout the Urashima stories recorded as Urashima Tarō, white cloud and smoke emerge from the box. Thus, the literal meaning is as follows: Urashima receives a beautiful souvenir box, which contains his soul inside, then when he opens the box, white smoke or clouds, which symbolise his soul, come out from the box, which signifies the time elapsed during his stay at the Sea Palace.

\footnotetext{
203 Palmer, 2011, 417.

${ }^{204}$ Palmer, 2011, 417-418.
} 
Japanese society is known for using giri (義理 duty), ninjō (人情 human feeling or emotion), honne (intention, true feeling), and tatemae (superficial obligatory practice). These are also seen as an influence of social behaviour in Otogizōshi. Readers of the Urashima story readers may question the reason why the Princess gives Tarō a beautiful souvenir box on his departure but then warns him not to open it. The Princess conveys tatemae (建前) in the form of a souvenir box as a gesture of good manners and hospitality as a farewell gift; but at the same time she conveys her true feelings of honne (本音) to Urashima Tarō as punishment for leaving her, which is to condemn him to instant old age. This is the core motif of the Urashima story because although the Princess is not happy about Tarō's departure, it would be rude not to treat him as a visitor, so she knows exactly what kind of gift to give him, and what is inside the box.

As analysed above, the Muromachi Period society and human behaviour influenced the entire symbolism of the "Urashima Tarō" in Otogizōshi through punning and the exchanging of songs which convey honne and tatemae in this way.

\section{Comparison of motifs 9: Urashima Tarō becomes a crane, is enshrined, the tale has a happy ending}

As was mentioned earlier, the pair of the turtle and crane are creatures symbolic of longevity. The meaning of the sentence 'Three lines of purple cloud puff out from the box' could be explained as that clouds symbolise good fortune and happiness. Auspicious clouds such as these are harbingers of peace, and clouds are correlated with the West. ${ }^{205}$ The West as already analysed and explained above relates to death in Taoist and Buddhist thought as well as happiness. ${ }^{206}$

Finally, Urashima Tarō becomes a crane in Otogizōshi and flies away to Mt. Hōrai, where he becomes Urashima Myōjin, the god of Urashima, and is enshrined in Tango Province. This thread is a completely new and different motif from the entire Urashima stories so far, due to the multi-lineage influence from previous Urashima stories and the strong influence of Buddhism, as well as the literary embellishment of the story. Therefore, it can be interpreted that the main character of Urashima Tarō in

\footnotetext{
${ }^{205}$ Eberhard, 1986, 67.

${ }^{206}$ See p56, 59 and 61.
} 
Otogizōshi actually dies, but this death of Urashima is not sad or the end of his life, but rather the beginning of a new life, through karma, with his partner, the turtle Princess, forever as a god. This is a very creative, sophisticated and more literary account of the tale compared to the previous recorded versions of the Urashima story.

\section{Conclusions: The Urashima Tarō in Otogizōshi in the Muromachi period}

In short, Urashima Tarō in Otogizōshi was compiled and published in the Edo Period, but it is believed to have been first recorded in writing in the Muromachi Period. The great cultural growth of the Muromachi Period had significant influence, changing much of the "traditional" Urashima tale transmitted from the Asuka to Heian Periods. The story not only evolved linearly via a particular version, but also evolved due to Muromachi Period influences such as Buddhism, renga (linked verse), tanka (traditional Japanese songs with 5-7-5-7-7 syllables) with various techniques of puns, double entendre, witty expression, and honne (real feeling) and tatemae (obligation). It is without doubt that the literary development of the story at this time had a significant effect on the Urashima story of successive periods, particularly the first appearance of the vocabulary tamatebako and the storyline of happiness, which is a notably creative evolution of the Urashima story. 


\section{CHAPTER 6: Edo Period (1603-1867 CE)}

\section{Historical overview: Edo Period (1603-1867 CE)}

The Urashima story is believed to have been published as Urashima Tarō, one of the twenty-three tales in Otogizōshi, at some point in the Kyōho Period (1716-1736 CE). ${ }^{207}$ However, the story Urashima Tarō is believed to have been first recorded earlier in the Muromachi Period. Thus people in the Edo Period were able to access Urashima Taro, and it was a transition phase for the Urashima story, in which the storyline contained more cultural elements and several hidden messages. This transformation and development continued in the Edo Period, which saw a more peaceful society through political stability, and in which newly developed genres of literature appeared. Furthermore, cultural and economic developments modified traditional Japanese elements. The Urashima story therefore developed further due to this historical and cultural background, forming the second transitional phase of the Urashima story.

It is well known that the more than two hundred and fifty years of Tokugawa Shogunate ensured a lasting peace that made possible a great upsurge in the domestic economy, extensively improved transportation and communication facilities, and sharp expansion in economic growth and the use of money. ${ }^{208}$ The rise of new and greater urban centres at Ōsaka and Edo created new culture, particularly among the middle and lower class townsmen. This included woodblock printing, ukiyoe (浮世絵 floating worlds) in painting, kabuki (歌舞伎 with live actors) and bunraku (文楽 with puppets) in theatre, ukiyozōshi (浮世草子 “books of the floating world”), kanazosshi (仮名草子 “kana books”), eroticism, poets such as Matsuo Bashō (松尾芭蕉 1644-94 CE) and flourishing of haiku in literature. The rapid spread of learning and literacy among all classes contributed to the pleasure and entertainment aspects of cultural development. ${ }^{209}$

The development and embellishment of the Urashima story in this period was not only influenced by the story itself, but also by this dynamic urban culture and the development of new genres of literature including humour, satire and comedy. In

\footnotetext{
${ }^{207}$ Matsumoto, 1963, 171.

${ }^{208}$ Varley, 1973, 113-116.

${ }^{209}$ Varley, 1973, 119-145.
} 
addition, the manufacture of paper and developments in printing are another important aspect of the Urashima story development. The development of woodblock printing contributed to the mass production of literature and its commercial sale; in addition, the literacy level increased in general, stimulating the publishing of books due to increased market demand in the Edo Period.

According to Chibbett (1977), "In the Edo Period, despite the fact that printing had to a large extent supplanted the manuscript, more manuscripts were produced than in any other period. This is not due to the increasing importance of the manuscript itself, but to the higher literacy level of the people."210 This is the primary reason that stories, tales and folklore spread all over Japan during this period, particularly in cities. The printing of books before the Edo Period was mostly confined to Buddhist monks, but Confucian teachings and non-Buddhist books started being printed for the first time by commercial publishers. In the Edo Period, the situation is therefore much more complex than previously, for printing and publishing became almost totally commercial in nature. ${ }^{211}$

The appearance of authors of literary works came predominantly from the samurai class, and the appearance of fiction such as ukiyo-zōshi and yomi-hon usually contained a great deal of text and were meant for the literate classes, while kuro-hon, and kibyōshi, catering to the semi-literate and to children, consisted mainly of pictures. The leading authors included Kyokutei Bakin (曲亭馬琴 1767-1848), Jippensha Ikku (十返舎一九 1765-1831), and Ryūtei Tanehiko (柳亭種彦 1783-1842) in the fields of yomi-hon (読本 “Books for reading”), kokkei-bon (滑稽本 “Humorous book”) and gōkan-mono (合巻物 “Illustrated story books") respectively. ${ }^{212}$

In addition to printing, the urbanisation of the cities made people more active in terms of communication and enabled people to travel throughout Japan. Marceau (2010) analyses the fictional writers and illustrators, one of whom, Jippensha Ikku, is used as an example, "His narrative and the process of bookmaking fulfils an

${ }^{210}$ Chibbett, 1977, 25.

${ }^{211}$ Chibbett, 1997, 79.

${ }^{212}$ Chibbett, 1997, 80. 
informational as well as an entertainment function, since such publications were primarily commercial in nature". 213

Also, the influx of people into the big cities such as Edo, Ōsaka and Kyōto brought new products, so that existing culture could not only develop but also absorb new culture, eventually producing a new domestic hybrid culture. As an example, Otogizōshi was published in Ōsaka but became popular in the Edo area too, leading to further development of the Urashima story due to a variety of influences of the distinctive Edo culture.

In short, the Urashima story is no exception, appearing in a variety of versions and newly developed storylines, such as the Mukashibanashi Urashima Jijī by Ryūtei Tanehiko (柳亭種彦 1783-1842) 214 and Ehon Urashima Tarō Kaichū Gunki (絵本浦島 太郎海中軍記 Picture book: The War Chronicles of Urashima Tarō under the Sea, author unknown $)^{215}$ due to the development of printing, publishers and the higher literacy level of people in general, which contributed to the mass production of books, more manuscript writers and also economic growth, production of paper and a more commercialised society, and the emergence of new culture and art, particularly the establishment of new literary genres such as romance, humour, witty books, success stories, sexually titillating stories and comics for townspeople.

Also the purpose of the recorded story became the enjoyment of literature itself, which shifted into the realm of hobby or luxury. These books appeared in small editions. The Urashima story not only appears at this time in books but also in theatre such as $n \bar{o}$ (能 traditional masked dance-drama), kyōgen (狂言 brief farce or comic interlude), yōkyoku (謡曲 a $n \bar{o}$ song), ${ }^{216}$ and in jōruri (浄瑠璃) ${ }^{217}$ as Urashima Nendaiki (浦島年代記 Urashima Chronicles) written by the playwright Chikamatsu Monzaemon

\footnotetext{
${ }^{213}$ Marceau, 2010, 405.

${ }^{214}$ Honda, 2006, 239-252.

215 Nakano and Hida, 1985, 153-158.

${ }^{216}$ Miura, 1989, 186-198.

${ }^{217}$ Jorrui is a type of chanted recitative that came to be used as a script in bunraku puppet drama. Encyclopædia Britannica online, "Jōrui", 2014. <http://www.britannica.com/EBchecked/topic/306273/joruri >. Accessed on 23 ${ }^{\text {rd }}$ Jan, 2014.
} 
(近松門左衛門 1653-1725). ${ }^{218}$ The analysis below is restricted to the Urashima tale as it appeared in narrative rather than dramatic form.

\section{Source No. 10: Ryūtei Tanehiko. "Mukashibanashi Urashima Jijī” (1830)}

In: Suzuki, Jūzō and Kimura, Yaeko (ed.). Kinsei kodomo no ehon shū, edo hen. Tokyo: Iwanami Shoten, 1985, pp. 458-475.

Appendix 1: Number 10, pp. 139-144.

\section{Mukashibanashi Urashima Jijī（むかしばなし浦島ぢ〉い Folktale: Grandpa} Urashima) was recorded by Ryūtei Tanehiko (1783-1842) in 1830 CE. ${ }^{219}$ This is a compilation of the three parts of Mukashibanashi Urashima Jiji Part1, 2 and Finale which are coloured picture books. ${ }^{220}$ These picture books are called ehon, which included many pictures, and Mukashibanashi Urashima Jijī is no exception, with half or more than half of each page being illustrated with beautiful and vivid pictures.

As can be seen in Appendix 1 Translation, number 10 (see pp. 139-144), the author wrote: "I asked a person from the Echigo ${ }^{221}$ region about stories for small children, and there are three or four folktales that are now extinct in Edo. This is one of them and I wonder if it should be called a variant of Urashima Tarō". So it seems that Tanehiko, the author, heard the story from somebody else, based on the folklore motif that is called ryūgū dōji (竜宮童子 the Sea Palace and the child), and added a little of his own originality and embellishment. ${ }^{222}$

The author of Mukashibanashi Urashima Jijī is recorded as Tanehiko Kikigaki (種彦聞書), literally “taken down by Tanehiko”. Kiki means to listen or hear, and gaki means to write. As mentioned, Tanehiko claims to have transcribed the story from a

\footnotetext{
218 Encyclopædia Britannica online, “Chikamatsu Monzaemon”, 2014. <http://www.britannica.com/EBchecked/topic/110980/Chikamatsu-Monzaemon>. Accessed on $21^{\text {st }}$ Jan, 2014.

${ }^{219}$ Honda, 2006, 248.

${ }^{220}$ Suzuki and Kimura, 1985, 500.

${ }^{221}$ Echigo (越後) is an old name region for present-day Niigata prefecture, except for Sado Island.

${ }^{222}$ Suzuki and Kimura, 1985, 500.
} 
version he heard, and so this is why he probably recorded his name as Tanehiko Kikigaki instead of Ryūtei Tanehiko. Honda (2006) describes Ryūtei Tanehiko as a gesaku writer (戯作者 geshakusha). ${ }^{223}$ The popularity of his masterpiece Nisemurasaki Inaka Genji (彥紫田舎源氏 Imposter Murasaki and Bumpkin Genji) series in 18291842 was the greatest in history to date. It sold more than ten thousand copies, and became the bestselling book of the Edo Period, after which Tanehiko's standing soared, so he is considered one of the masters of gesaku. ${ }^{224}$ Therefore, it could be said that the Urashima story was already so popular in the Edo Period that one of the greatest gesaku writers, Ryūtei Tanehiko, recorded Mukashibanashi Urashima Jijī the year after completing his masterpiece Nisemurasaki Inaka Genji, thereby turning the Urashima story into the new genre of gesaku.

\section{Comparison of motifs 1: the main character and the turtle, Tarōsaku and Kamez̄̄}

The main character name in Mukashibanashi Urashima Jiji is Tarōsaku, who is close to the age of seventy, and is married to a woman, Minawa. He does not catch a turtle, but a turtle called Kamezō in human form comes to Tarōsaku, and converses with him. The name Tarōsaku is a linear development from Urashima Tarō in the previous story of Otogizōshi published in 1716-1736, as Tanehiko would have been familiar with that version. However, Kamezō is described as a messenger from the Princess of the Sea Palace, making the turtle and the Princess different characters for the first time.

\section{Comparison of motifs 2: Seiōbo, ${ }^{225}$ a beautiful woman}

Nani, Seishi and Yōhi were described as metaphoric expressions of the beauty of the woman in the Urashima story in earlier versions, but Seiōbo, a new name to describe a beautiful woman, appears in Mukashibanashi Urashima Jijī. Seiōbo (西王母

\footnotetext{
${ }^{223}$ Gesakusha (戯作者), an alternative style or genre of Japanese literature and a novel in the Edo Period, general terms for yomihon, kibyōshi, sharebon, kokkeibon and ninjōbon. Shimmura, 1993, 801. ${ }^{224}$ Honda, 2006, 2, and 247-252.

${ }^{225}$ Seiōbo (西王母 Xi Wangmu) is a mythical Chinese goddess known from the ancient times. Sekai Daihyakka Jiten, "Seiōbo", kotobank, 2013.

<http://kotobank.jp/word/\%E8\%A5\%BF\%E7\%8E\%8B\%E6\%AF\%8D?dic=daijisen\&oid=101012 00>. Accessed on $24^{\text {th }}$ Jan, 2014.
} 
Chinese: Xi Wangmu) is a mythical Chinese goddess known from ancient times.

Seiōbo is also one of the $n \bar{o}$ drama plays in Japan, ${ }^{226}$ so that Tanehiko uses Seiōbo instead of Nani, Seishi or Yōhi because $n \bar{o}$ was already established by the time Tanehiko recorded Mukashibanashi Urashima Jiji in 1830, and he may have chosen to use Seiōbo as one of his embellishments because of this Edo cultural development.

\section{Comparison of motifs 3: The Sea Palace $(r y \bar{u} g \bar{u})$ under the sea}

In Urashima Jijī, the Sea Palace is described as actually under the sea for the first time, because Kamezō invites Urashima and they dive together into the sea. Perhaps people in the Edo Period, or perhaps Tanehiko himself, placed less value on Mt. Hōrai and Tokoyo. Instead imaginary stories that attracted more of an audience in the Edo Period may have prompted him to revise the storyline like this, to suit the culture at the time, and he portrays the Sea Palace as a more attractive-sounding backdrop for the story. This is possibly the motive for the Sea Palace being described as under the sea from the Edo Period on, which becomes the popular norm for Urashima stories thereafter.

\section{Comparison of motifs 4: Tarōsaku's wife Minawa}

Mukashibanashi Urashima Jijī is the only version in which the main character is already married, and he is described as a very old man compared to other versions of the Urashima story. Tarōsaku is close to seventy years old and his wife, Minawa, is sixty years of age. Minawa is described as not a mean person but as a very avaricious woman. Although Tarōsaku is invited to go to the Sea Palace (ryūgūjōo) and receives a souvenir from the Princess Otohime, Minawa is dissatisfied with Tarōsaku's choice. By the end of the story, Minawa is punished because of her greed, but finally Tarōsaku and Minawa receive an abundance of gold coins and both of them are rejuvenated into young people: Tarōsaku becomes twenty years old again and Minawa looks sixteen to seventeen years of age, much to their surprise. But Minawa has also learnt a lesson from her greed and reforms her avaricious heart, so this obviously serves as a moral

${ }^{226}$ Shimmura, 1993, 1407. 
lesson against greed. The appearance of money could also be interpreted as influenced by Edo Period economic growth and the beginnings of a widespread cash culture, because greed for money is not a common or prominent motif in the Urashima story in general.

\section{Comparison of motifs 5: No box or smoke but a happy ending to the Urashima story}

Mukashibanashi Urashima Jijī does not finish the story as just a moral lesson, but also with some aspects of chōninmono (町人物 merchant success stories). As can be seen in Appendix 1 Translation (see pp. 139-144), 'Tarōsaku and Minawa moved to the vicinity of Kireto, and opened an inn with the capital received from the box. Gradually his business prospered. And the sake which he called Shianzake created much wealth for them. The character saku, of Tarōsaku, was not suited to a young man, so he changed his name to Tarō. In no time at all Minawa became pregnant. She gave birth to a lovely baby boy, and they lived there happily ever after without any difficulties at all. A very fine and happy ending!' This is an entirely new storyline and ending for the Urashima story: there is no souvenir box, no smoke appears, and there is no end to Tarōsaku's life. Rather, the main character who had humbly asked for a girl doll as a souvenir at the Sea Palace becomes rejuvenated, and he becomes very happy without any concerns for life with his family. This appears to have been a simpler thread and message that common people were able to enjoy reading, which also suited the urbanisation of the Edo Period.

\section{Conclusion of the Urashima story in the Edo period}

In short, Mukashibanashi Urashima Jijī seems almost like a parody of earlier versions, and is a comical and humorous story because of the influence of dynamic urban culture allowing common people to enjoy this fictional Urashima tale. The appearance of the new literary genre of gesaku enabled its author to modify the storyline to a considerable extent. At the same time, the mass production of printing 
and the manufacture of paper enabled people to access these books, and economic growth allowed a wider proportion of the population the luxury hobby of reading them.

In addition, the lineage development of rysugujjo and the main character name of Tarō are inherited but developed from the Muromachi Period, and the location of the Sea Palace as under the sea is introduced for the first time. Such storyline changes in the Urashima story in the Edo Period meant the story had already developed quite differently from earlier versions. Another important development of the Urashima story is the change from merely a recorded story to a fictional literary reading book for the general public, leading to it becoming one of the most popular Japanese stories derived from folklore. 


\section{CHAPTER 7: Meiji Period (1868-1912) $)^{227}$ to Post Second World War}

\section{Historical overview: Meiji Period (1868-1912)}

As seen above, the Urashima story changed drastically in the Edo Period because of the Edo period cultural influences, but it developed further still because of cultural development during the Meiji Period. People in Japan started to attend school with the establishment of the compulsory state educational system (from around 1872) which stimulated a higher literacy rate and even more widespread access to books and stories. Contact with the West also influenced the Meiji culture greatly, a time often described as the modernisation of Japan.

The Meiji Period was often described as "troubles within, disaster from without" (naiy $\bar{u}$ gaikan 内憂外患). ${ }^{228}$ However, Japan changed drastically during this period due to Westernisation and the abolition of the feudal land system $(1871),{ }^{229}$ the creation of a new school system (1872), adoption of the Cabinet system of government (1885), promulgation of the Meiji Constitution (1889), and opening of the Diet (1890). ${ }^{230}$ The new school system that was established contributed to the rise in literacy among the Japanese people and greater access to Western books in addition to Japanese tales and folklore. This modernisation during the Meiji Period contributed to the evolution of the Urashima story, and the story was modified and rewritten for the younger target audience of school children.

In 1890 it was decided that the 'turn to the West' had been too sudden and extreme, so the Japanese government sought an identity of Japan's own within the lines of Confucian and Shintō ideology, resulting in the issue of the Imperial Rescript on Education (Kyoiku Chokugo 教育勅語) which later constituted the moral content of Japanese education. ${ }^{231}$ As will be seen, this also influenced the further development of the Urashima tale.

\footnotetext{
${ }^{227}$ Shimmura, 1993, 2510.

228 Jansen, 1990, 308

${ }^{229}$ Jansen, 1990, 370-373.

${ }^{230}$ Encyclopædia Britannica online, "Meiji”, 2014. <http://www.britannica.com/EBchecked/topic/373294/Meiji>. Accessed on 22 $2^{\text {nd }}$ Jan, 2014

${ }^{231}$ Jansen, 1990, 495-498.
} 


\section{Source No. 11: Iwaya, Sazanami (author) and Ueda, Nobumichi (annot.). Nippon Mukashibanashi, No. 18 Urashima Tarō (1896). Tokyo: Heibonsha, 2001, pp. 270-280.}

Appendix 1: Number 11, pp. 145-150.

Nippon Mukashibanashi is twenty-four volumes of books published monthly from 1894-1896 CE by Iwaya Sazanami (嚴谷小波 1870-1933), ${ }^{232}$ a children’s story writer, of which Urashima Tarō is volume 18 and was published in February 1896. ${ }^{233}$ Ueda (2001) notes that Nippon Mukashibanashi is one of the most important products of Sazanami, who was born into a doctor's family and studied German in order to become a doctor. Later he changed his career towards the literary field, and joined the Designated Textbook Editorial Panel as a temporary employee at the Ministry of Education. $^{234}$

The publication of Nippon Mukashibanashi was originally scheduled for only twelve volumes, but it enjoyed great success in sales so it was expanded into twentyfour volumes, and the payment per manuscript was doubled from five yen to ten yen. Sazanami was also a noted novelist working for the Kenyūsha (硯友社) group and the Hinode Shimbun (日出新聞 “Sunrise Newspaper”, later called Kyōto Shimbun 京都新 聞, “Kyōto Newspaper”), as a novel or short story writer, so it was a natural progression that the publishing company Hakubunkan approached him to plan the publishing of children books by an individual author for the first time in Japan. Together with his friend Ōhashi Shintarō (大橋新太郎 1863-1944) ${ }^{235}$ from Hakubunkan, Sazanami decided to edit folktales into standardised stories. The high volume of book sales led to Sazanami publishing other books that were not able to be included in Nippon Mukashibanashi, newly publishing Nippon Otogizōshi in twenty-four volumes in 1896-

\footnotetext{
232 Shimmura, 1993, 194.

${ }^{233}$ Miura, 1989, 41.

${ }^{234}$ Ueda, 2001, 467-470.

${ }^{235}$ Digital Daijisen, “Ōhashi Shintarō”, kotobank, 2014. < http://kotobank.jp/word/大橋新太 郎?dic=daijisen\&oid=02229600 $>$. Accessed on $27^{\text {th }}$ Aug, 2014.
} 
1899, Sekai Otogizōshi, in a hundred volumes in 1899-1908, and Sekai Otogibunko, in fifty volumes in 1908-1915. ${ }^{236}$

As a result, people in the Meiji Period were able to access mass-produced printed books and standardised folk tales, and the emergence of a specialist Japanese children's author enabled this. The fact that the Urashima story appears in the Nippon Mukashibanashi series as Urashima Tarō demonstrates the enduring popularity of the Urashima story, and is one of the reasons why the Urashima story is such a popular and well-known story in Japan even today.

In addition, this version contains many humorous and satirical expressions, particularly in the conversations between Urashima Tarō and the turtle, which is another reason the book became popular. Sazanami was able to access the previous Urashima stories from the Edo Period, but he is responsible for changing the Urashima tale into a standardised story through publishing it in the series of books Nippon Mukashibanashi.

\section{Source No. 12 and 13: Ministry of Education Designated text book (Kokutei}

\section{Kyōkasho)}

No. 12. Furuta, Tōsaku. “Urashima no hanashi” (1910-1917, Ministry of Education Designated textbook, $2^{\text {nd }}$ edition), Shōgaku Dokuhon Binran, vol. 6. Tokyo: Musashino Shoin, 1983.

In: Miura, Sukeyuki. Urashima Tarō no bungakushi. Tokyo: Goryū Shoin, 1989, pp. 22-23.

Appendix 1: Number 12, pp. 150-151.

No. 13. Furuta, Tōsaku. "Urashima Tarō” (1918-1932, Ministry of Education Designated textbook, $3^{\text {rd }}$ edition), Shōgaku Dokuhon Binran, vol. 6. Tokyo: Musashino Shoin, 1983.

${ }^{236}$ Ueda, 2001, 467-468. 
In: Miura, Sukeyuki. Urashima Tarō no bungakushi. Tokyo: Goryū Shoin, 1989, pp. 22-23.

Appendix 1: Number 13, pp. 151-152.

Miura (1989) explains that the Ministry of Education Designated text book (Kokutei Kyōkasho) system was established by the Ministry of Education in 1903 for use by all primary school students in Japan. The first edition of the Ministry of Education Designated textbook was issued during a period of rapid modernisation; while the launch of the second edition was during a period that was characterised by rapid modernisation and the development of Western civilisation in Japan; and the third edition Ministry of Education Designated textbook was released during a period of mature Japanese modernisation. The period can be seen as a time of relative freedom for Japanese civilians, and the textbook was designed for Taishō democracy ${ }^{237}$ based on the internationalisation of civil ethics. ${ }^{238}$

There were actually six editorial versions of the Ministry of Education Designated text book from 1904-1949, and they contain the Urashima story from the second to the sixth editions. ${ }^{239}$ The second edition, in use 1910-1917, called Jinjō Shōgaku Tokuhon (尋常小学読本 Reading Book for Elementary Schools), vol. 3 (Semester 1, Year 2), which is also called Hatatako Tokuhon (ハタタコ読本 Hata-tako Reading Book), contains "Urashima no hanashi” ("The Story of Urashima”). The third edition from 1918-1932, titled Jinjō Shōgaku Kokugo Tokuhon (尋常小学国語読本 Japanese Reading Book for Elementary Schools), vol. 3, contains a different title, "Urashima Tarō". The third edition version is a book well-known as Hanahato Tokuhon (ハナハト読本 Hana-hato Reading Book).

It is noteworthy that slight wording differences can be seen between the second and third versions, with the same two pictures inserted: these illustrate the main character of Urashima running to the rescue of the turtle being bullied by children, and

\footnotetext{
237 Taishō democracy is a democratic movement that occurred in the Taishō Period (1912-1926) such as supporting the constitution and franchising the universal voting right. Simmura, 1993, 1544-1545. ${ }^{238}$ Kogawa, 1985, 32-33.

${ }^{239}$ Miura, 1989, 21. See also Kogawa, 1985, 17, 32-34.
} 
the other of Urashima on the turtle's back holding the tamatebako (the beautiful box) to return to his homeland when the Princess sees him off at the ryūgūjō (the Sea Palace). ${ }^{240}$

Kogawa (1985) states that textbook history in Japan started in the Nara Period with aristocrats' children; due to the popularisation of printed books in the mid Edo Period textbooks then rapidly became generalised, but they were used differently. One version was the Chinese classical style used in private schools (藩校 hankō) for the children of samurai families, and the other was for the children of the townspeople or peasants at private temple schools, terakoya (寺子屋 mostly in towns, where they functioned as elementary schools: reading, writing, and arithmetic were taught by monks, unemployed warriors, or others). ${ }^{241}$

It is noteworthy that the now well-known Urashima Tarō songs were released almost at the same time as the Ministry of Education Designated textbook: 'Urashima Tarō' in Yōnen Shōka in 1900, and 'Urashima' in Jinjō Shōgaku Shōka also known as Mombushō Shōka in 1911, so Urashima Tarō not only appeared in the textbook at primary schools, but also appeared in school song books, and the name Urashima Tarō became well known to all Japanese children without exception at this time. ${ }^{242}$

The Meiji educational system introduced the Urashima story through the Meiji Period to the Shōwa Period (1926-1989 CE) and influenced the masses for about fortyfive years ${ }^{243}$ Therefore, the Ministry of Education Designated textbooks at primary schools and the songs are one of the major reasons for the Urashima story's enduring popularity, and it remains one of the most well-known children's stories today.

\section{Comparison of motifs 1: Children bullying a turtle}

A difference in terms of the story title is only found in the second Ministry of Education Designated textbook, in which it appears as "Urashima no hanashi" ("The Story of Urashima"), but the other two versions, in the third Ministry of Education

\footnotetext{
${ }^{240}$ Miura, 1989. 25.

${ }^{241}$ Encyclopædia Britannica online, “Japan”, 2014. <http://www.britannica.com/EBchecked/topic/300531/Japan/23304/Housing\#toc23296>. Accessed on $25^{\text {th }}$ Jan, 2014. See also Kogawa, 1985, 17.

${ }^{242}$ Miura, 1989, 36.

${ }^{243}$ Shimmura, 1993, 1289.
} 
Designated textbook and Nippon Mukashibanashi, are "Urashima Tarō". The main character's name in all of these is known in common as Urashima Tarō.

However, a new motif in common appears in all three versions: the children bully a turtle. The first encounter in the story is that Urashima Tarō rescues a turtle from being bullied by children. This motif appears in no previous versions of the Urashima story, but it is thought to be influenced by Buddhist teachings, in which buying a turtle or other animals to rescue and release them later is seen in Nihonryōiki (日本霊異記 Miraculous Stories from the Japanese Buddhist Tradition, 822-824 CE?) ${ }^{244}$ and Konjaku Monogatarishū (今昔物語集 The Collection of Tales of Past and Present, late Heian Period or after $1120 \mathrm{CE}),{ }^{245}$ among other works. ${ }^{246}$

Iwaya Sazanami seems to have adopted a similar approach, probably not particularly with Buddhist teaching in mind, but the storyline matches the moral lessons taught to young children at school under the modernisation, liberalisation and freedom philosophy of the Meiji Period.

\section{Comparison of motifs 2: Elapsed time, reference to smoke and moral lesson}

All three versions of the Urashima stories — in the second and third Ministry of Education Designated textbooks and Iwaya's "Urashima Tarō" in Nippon

Mukashibanashi - are similar in content except for in regard to the elapsing of time, and the period of seven hundred years. However, it can be surmised that the Nippon Mukashibanashi version is largely derived from Otogizōshi due to the same expression in the ending of "three lines of purple cloud", which is only seen in Otogizoshi and Nippon Mukashibanashi.

On the other hand, no description matches the Ministry of Education Designated textbook for both elapsed time and the smoke compared to Nippon Mukashibanashi. There is no description of time elapsing or a purple cloud, but instead, it merely describes 'white smoke', although Urashima Tarō receives a tamatebako (a beautiful box) or hako (a box). Perhaps because it does not match the moral lessons desired for

\footnotetext{
${ }^{244}$ Shimmura, 1993, 1964.

245 Shimmura, 1993, 985.

${ }^{246}$ Miura, 1989, 43.
} 
young children in the Meiji Period, Sazanami presumably thought that Urashima Tarō should rescue the turtle, and receive hospitality and a souvenir from the Princess at the Sea Palace in return for the rescue. This is the first appearance of the motif of rewarding Urashima with a trip to the Sea Palace for rescuing the turtle.

However, Urashima spends too much self-indulgent time enjoying hospitality, and does not refuse the lavish feast or the temptation of the Princess. By forgetting his parents, Urashima is also disrespectful of them, which is not acceptable according to contemporaneous Confucian ethics of filial piety, so young children were to learn from this story the moral lesson of humility and appreciation of one's family and parents.

Therefore, there is no need to include seven hundred or three hundred years of elapsed time. Instead, the white smoke suffices to portray the moral lesson because Urashima turns into an old man as punishment for his self-indulgence. It is also possible that people in general in Japan were no longer familiar with the traditional significance of the colour purple due to Westernisation and the liberalisation seen during the Meiji to Taishō Periods.

\section{Conclusion of the Urashima story in the Meiji and Taishō Periods}

In short, development in the Urashima story through the Meiji and Taishō Periods is restricted to Iwaya Sazanami's standardisation in Nippon Mukashibanashi and the Ministry of Education Designated textbooks, aimed at young school children under the Educational Reform (Kyōiku Chokugo) in 1890 which promulgated the moral content of later Japanese education until the end of the Pacific War in 1945. In addition, the children's story writer Iwaya Sazanami is a key influence in the Urashima story from the Meiji Period onwards: his standardised version of the Urashima tale is not only a concise version of previous Urashima stories, but also a simplified, embellished, modern version of the Urashima story. 


\section{Historical overview: Taishō Period (1912-1926 CE) $)^{247}$}

The economic growth of this period was in peaks and troughs; the growth rate saw rapid development by the 1920s, followed by a slowdown during the 1920s, and then another period of growth in the 1930s. ${ }^{248}$ Varley (1973) states that the Taishō Period saw the emergence of popular culture in Japan; and advances in public transportation, communications, higher education, publishing, and journalism were among factors that contributed to 'cultural life', particularly for middle-class urban dwellers. ${ }^{249}$ Therefore, the Urashima story was without a doubt influenced by Taishō liberalism, internationalism and the democratic movement (voting system and liberal ideology), despite the period only lasting fourteen years.

\section{Historical overview: Shōwa Period (1926-1989) ${ }^{250}$}

The Shōwa Period experienced further economic growth, with privatised profit and property providing the main incentives for growth, but during the 1930s, reformist bureaucrats, intellectuals, and politicians called for an end to a 'liberal economic structure' and the establishment of a 'control economy'. ${ }^{251}$ However during the post war period until 1955, the Economic Planning Agency was responsible for economic forecasting and overall indicative economic planning. ${ }^{252}$ Although suffering post war depression, the Japanese economy rapidly revitalised and became a world class economy.

The period of post war reconstruction is vividly described in the writings of Dazai Osamu (太宰治 1909-1948), notably in Shayo (斜陽 The Setting Sun, 1947). ${ }^{253}$ Other representative works were Nobi (野火 Fires on the Plain, 1951) by Ōoka Shōhei

\footnotetext{
${ }^{247}$ Shimmura, 1993, 1544.

${ }^{248}$ Dunn, 1990, 18.

${ }^{249}$ Varley, 1973, 206-207.

${ }^{250}$ Shimmura, 1993, 1289.

${ }^{251}$ Dunns, 1990, 19-20.

${ }^{252}$ Dunns, 1990, 21.

${ }^{253}$ Encyclopædia Britannica online, “The Setting Sun”, 2014. <http://www.britannica.com/EBchecked/topic/1782715/The-Setting-Sun>. Accessed on $28^{\text {th }}$ April, 2014.
} 
(大岡昇平 1909-1988), ${ }^{254}$ which described defeated Japanese soldiers in the Philippine jungles. Kuroi ame (黒い雨 Black Rain, 1966) by Ibuse Masuji (井伏鱒二 1898$1993)^{255}$ succeeded in suggesting the ultimately indescribable horror of the disaster in Hiroshima.

Despite the war damaged era after 1945, the Urashima story still survived and was actively rewritten by one of the above-mentioned literary authors, Dazai Osamu. Encyclopædia Britannica online (2014) explains that "Dazai was deeply concerned with his craft, and his stories were far from being mere confessional documents; nevertheless, his artistry was often obscured by the wide publicity given to his dissipation, a source of continued attraction, especially to youthful readers", and Otogizōshi (The Fairy Tale Book, 1945), new versions of traditional tales, represented a triumph of his style and wit. ${ }^{256}$ Dazai's version is as if it were a modern sardonic parody of the traditional Urashima story.

On the other hand, Matsutani Miyoko (松谷みよ子 1926- ), a children’s author, also wrote Urashima Tarō in 1967 as an illustrated book with beautiful pictures by Iwasaki Chihiro. This may be regarded as a modern version of the Urashima story after the Ministry of Education Designated textbook. Hence, the Urashima story entered another phase of development with a rich and strong economic background, but still maintaining the essence of the folklore in the storyline.

\section{Source No.14: Dazai, Osamu. "Urashima san", Otogizōshi. Tokyo: Shinchō Bunko, 1972, pp. 236-277.}

Refer to: Dazai, Osamu. McCarthy, Ralph F (trans.). Otogizōshi: the fairy tale book of Dazai Osamu. Fukuoka: Kurodahan Press, 2011, pp. 2365 .

\footnotetext{
254 Shimmura, 1993, 322.

${ }^{255}$ Shinchōsha Publishing, "Ibuse Masuji”, 2014. <https://www.shinchosha.co.jp/writer/863/>. Accessed on $24^{\text {th }}$ Feb, 2014.

${ }^{256}$ Encyclopædia Britannica online, “Dazai Osamu”, 2014. <http://www.britannica.com/EBchecked/topic/153214/Dazai-Osamu>. Accessed on 27 Jan, 2014.
} 
Appendix 1: Number 14, not provided. Refer to the book above.

Okuno Takeo in Otogizōshi (1972) states, "Dazai wrote Otogizōshi in July 1945 just before the end of the Second World War in August. He was in a bomb shelter when he finished writing this Otogizōshi based on the illustrated book of the Urashima story. Dazai puts his views of life, art, morals, thought and his real life experience into this story, and creates the story as art. Also the theme of this book was personality, destiny and the changeless part of society, politics and psychology". ${ }^{257}$ Okuno (1972) continues that in "Urashima san" in Otogizōshi, Dazai imagines an anti-modernist world where everything is permitted and is boundlessness with no criticism - this is a utopian novel. Although his mental fatigue and desperation can be felt through this story, his rich and fantastic description of under the sea, and artistic and elegant philosophical discussion with the turtle can also be seen. So "Urashima san" is a reflection of Dazai's own life story, anxiety and thought. He did not create a new story, but instead inserted his ideas and wartime uncertainty into the existing narrative of the Urashima story. Therefore, it makes for quite a different type of Urashima story compared to previous versions.

\section{Source No.15: Matsutani, Miyoko illustrated by Iwasaki, Chihiro. Urashima Tarō. Tokyo: Kaiseisha, 1967. \\ Matsutani, Miyoko illustrated by Iwasaki, Chihiro. Tresselt, Alvin (trans.). The fisherman under the sea. New York: Parents' Magazine Press, 1969.}

Appendix 1: Number 15, pp. 153-156.

This Urashima version by Matsutani Miyoko, an author of children's literature, may be regarded as the orthodox version of the contemporary Urashima story, and is known as Urashima Tarō. The storyline, motifs and characters are similar to the Ministry of Education Designated textbook of the pre-war period, and it is likewise an

${ }^{257}$ Okuno, 1972, 341-342. 
illustrated book for children, so it is clearly in the lineage of development from the Meiji to Taishō versions of the Urashima story. The book was published in 1967, when economic growth and the literary world were quite different from in the Meiji and Taishō periods, so this version may be regarded as another embellished story.

\section{Comparison of motifs 1: Tango no Mizunoe}

Dazai wrote the place name as Mizunoe in Tango at the start of his tale, so he not only referred to the Otogizōshi, Nippon Mukashibanashi, Mukashibanashi Urashima Jiji and the Ministry of Education Designated textbooks versions, but also to the early historical versions of the Urashima story. As can be seen in Table 1 (see pp. 101-108), the "Urashimako Den" in Kojidan, Gunshoruijū (both stories) and Fusōryakki (the first story) have this Mizunoe and Tango pattern. Dazai would certainly have been familiar with the eighth century classics, such as Nihonshoki, Manyōshū and Tango no Kuni Fudoki Itsubun, which also contained these place names, so he seems to have had access to previous versions of the Urashima story.

By contrast, Matsutani's version of Urashima Tarō does not mention the place name at all. It could be surmised that the place name was no longer of significance for children, but instead the bullying of the turtle and its rescue was in fact more important for the storyline, so there was merely a description of a village by the sea that could be anywhere in Japan.

\section{Comparison of motifs 2: Loggerhead turtle and the Sea King}

A new description of the turtle appears for the first time in Dazai's version, as a loggerhead turtle (アカウミガメ akaumigame). This is no longer a beautiful fivecoloured or mysterious turtle, but it is specifically identified as a loggerhead turtle. Dazai satirically describes that the common turtle in Japan is ugly and small, so they could not reach the Sea Palace under the sea, and anyway they would suffocate before they reached the bottom of the sea. He decided to describe it as a large turtle that he had actually seen in Japan, so he chose the loggerhead turtle. Also, the turtle in Urashima san is a very comical and sarcastic character. This is Dazai's sardonic but humorous 
talent of literary skill, and because he knew a lot of different versions of the Urashima story it seems that he purposely did not describe the turtle the same as in previous versions.

However, in Matsutani's version two different turtles appear: one is a fivecoloured small turtle on the beach which is bullied by children, while the other is a big turtle that approaches Urashima Tarō a couple of days after the rescue of the small turtle. So this resembles the description in the Tango no Kuni Fudoki Itsubun version of the Urashima story. The idea of five colours is not in fact from Buddhism, but is based on Confucianism, and Daoism spread the notion of five colours to the public in China. However, by this time it was not so symbolically important how many colours it had, but rather, that the beautiful turtle is more attractive for younger children due to the illustrations. So it is evident that, given the target audience, the purpose of describing the turtle as five-coloured is different from the Tango no Kuni Fudoki Itsubun version.

The baby turtle does not come back to Urashima Tarō, but instead, a bigger turtle comes back and invites Urashima Tarō to the Sea Palace. These two different turtles could possible portray the moral teachings of family dynamics in mid-twentiethcentury Japan. Once a small child is rescued by a stranger, it is thought only natural that it should be the parents who would come back and express their appreciation for the rescue, and given that the formal invitation would come from the head of the family, in this case the Sea King at the Sea Palace, there would have to be an adult messenger. The family dynamics in 1960-1970s when Matsutani's version was written were still dominated by the concept of a male head of the household, not to mention that Japanese society in general was male dominant, so the Princess as the authority figure would not have matched the social norms at the time. Still, the Urashima story is a linear development from the previous versions, but the hidden messages in the story as a moral lesson are developed further.

\section{Comparison of motifs 3: Peach petal, hope and smoke}

Dazai describes the peach petal in the sea as actually some flavours of sake, and white smoke represents hope for the future, both new concepts for the Urashima story. The first is the appearance of the peach. Urashima and the turtle are having a 
conversation under the sea when the turtle describes some beautiful purple flowers of a peach tree (桜桃 $\bar{o} t \bar{o})$, saying that when you eat its petals in the Sea Palace you get drunk, as though it were a kind of sake (酒 Japanese rice wine). The use of peaches in Japanese folk stories is thought to come from Chinese Daoism. ${ }^{258}$ They symbolise eternity or belief in immortality (神仙思想 shinsen shisō), and are thought to be a powerful fruit for attaining longevity in Japanese mythology.

Dazai challenges the norm of the Urashima story in this scene because white smoke can be interpreted as the end of Urashima's life or as Urashima's soul and he becomes an old man. Dazai challenges the preconceived notion that this is a sad element; and suggests that Urashima was fortunate to live three hundred years. There is nothing in the Urashima story in general that says he spent a tragic life or that it was particularly regrettable. Dazai adds one last sentence at the end of "Urashima san": 'It is said that Urashima Tarō lived another ten years as a happy old man'. Dazai uses Urashima Tarō and the Urashima story as a vehicle to express his own thoughts and challenges towards society, which probably stemmed from war time economic depression and uncertainty for the future. His message through his literary skill and this parody version is for people to be happy and enjoy a happy end to life-which tragically he did not attain himself.

\section{Comparison of motifs 4: Three hundred years}

Dazai mentions the elapsing of three hundred years, and tries to relate the box to the smoke. He emphasises 'three hundred' at the end of this story, such as "suddenly he became a three hundred-year-old man", "oblivion of three hundred years of time" and "changed to a three-hundred-year-old grey-haired man". Traditionally the even number 'eight' was widely regarded as a sacred number in Japan, and an indeterminate large number or great numbers are often referred to as 'eighty' or 'eight hundred' in Japanese mythology, but the number three is used less and tends to denote a small number. ${ }^{259}$ Dazai describes that people could get disillusioned if they lived three hundred years. A hundred years old is too believable to describe a person suddenly becoming an old man,

${ }^{258}$ Miura, 2006, 30.

${ }^{259}$ Miura, 2006, 43. 
so he seems to have used this mythology pattern of the "number three" to exaggerate in order to have a greater impact on the reader.

Similarly, as can be seen from Table 1 (see pp. 101-108), Matsutani’s version describes the lapsed time as three hundred years, which is in the direct lineage succession from Tango no Kuni Fudoki Itsubun and is the only other version in which the expression of three hundred years appears. So Matsutani in 1967 was still greatly relying on previous versions of the Urashima story. She presumably changed the style of the illustrated literature because the main readers she aimed at were children. 


\section{Comparison of motifs 5: A diagram of the linear development of the Urashima story from the Muromachi "Urashima Tarō", Otogizōshi to the Shōwa Period.}

Diagram 2. The development of the Urashima story from the Muromachi "Urashima Tarō”, Otogizōshi to the Shōwa Period.

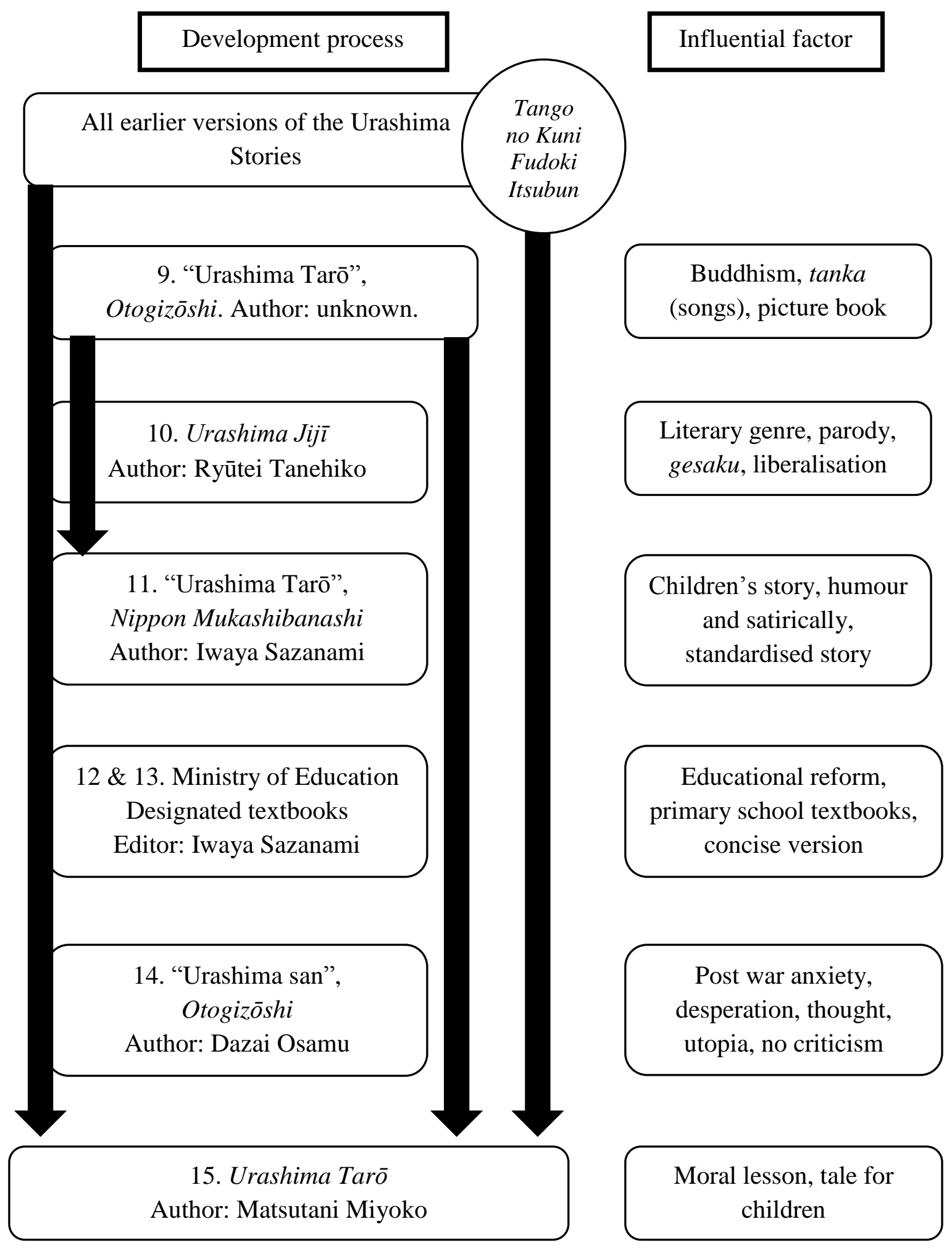




\section{Conclusion of the Urashima story in Postwar Shōwa period}

In short, there were two different versions of the Urashima story in the Shōwa Period, and particularly, of those of the post war period examined here, "Urashima san" in Otogizōshi by Dazai Osamu has quite a different flavour and purpose, reflecting as it does the perspective of his personal thoughts and anxieties for the future during war time. Dazai uses the Urashima story as a tool to relay his message, and rearranges the storyline as a parody of his life experience.

In contrast, Urashima Tarō by Matsutani Miyoko is a folklore-based illustrated piece of literature for children. It contains lineage development traceable from the Tango no Kuni Fudoki Itsubun version and Otogizōshi, characters and motifs identical with the very old versions of Urashima, and in addition, moral lesson types of doctrine are hidden within the storyline.

\section{Conclusion of Part Three}

Several versions of the Urashima story were recorded before the Muromachi Period, and these stories changed in style and form into "Urashima Tarō" that appeared as one of the twenty-three booklets of Otogizōshi in the Edo Period. However, the Urashima Tarō text itself is believed to have been recorded beforehand in the Muromachi Period, due to its style and the contents. It contains the traditional Japanese songs and witty expressions, hidden messages, satire and double entendre, symbolises the Four seasons and the Four Symbols of animals of Chinese origin, as well as Buddhist influenced wording, plus literary development of imaginative description of the main character of Urashima Tarō and the Sea Palace (ryūgūjō) for the first time. Therefore, Otogizōshi version of Urashima Tarō is a multi-lineage development of the Urashima story from all previous recorded versions, but this version appeared as the first individual monograph for the first time in the Edo Period.

Many versions of the Urashima story existed that were accessible in the Edo Period due to the dynamics of urban cultural growth, economic development and stability, peaceful politics, the appearance of gesaku writers and higher rates of literacy among townspeople, manufacture of paper and printing technology, and the shift in audiences from Buddhist monks, the aristocracy and educated samurai class to the townspeople. 
In tandem with this, the development of literary genres such as yomihon, kokkeibon, sharebon and others were created. In addition, the Urashima story appears not only in literature but also in theatre such as kyōgen and yōkyoku, which indicates the popularity of the Urashima story in the Edo Period. It was also influenced by the increase in the numbers of manuscript writers which contributed to the expansion of the Urashima story as a book, and the previous Otogizōshi versions of the story became the prototype of the Edo Period 'Urashima Tarō' versions. One of these gesaku writers, Ryūtei Tanehiko, wrote a parody version of the Urashima story as Urashima Jijī, and the location of the Sea Palace was described as being under the sea for the first time.

In the Meiji Period, liberalisation and modernisation supported the further development of the Urashima story. Iwaya Sazanami, a writer of children's literature, published Nippon Mukashibanashi, a very successful book in terms of sales, and he published other children's literature later too. At the same time, educational reforms prompted the publication of the Ministry of Education Designated textbooks at primary schools in Japan, so that Iwaya became one of the editors for these at the Ministry of Education.

The Urashima story was selected, but storyline plot and the message needed to be changed in order for young children to understand and enjoy the story, as a result of which the textbook version of the Urashima story appeared throughout the Meiji to Shōwa Periods for almost forty years continuously at primary schools in Japan. That is the reason why Japanese people know the Urashima story so well as Urashima Tarō, which is not only a lineage development from the Otogizōshi and Tango no Kuni Fudoki Itsubun versions, but is also modified due to the target readers of young children. It needed to be a moral lesson type of storyline to suit the political climate of the day. It was a simplified version, however, since the cultural growth and the development of the Shōwa Period required the Urashima story to be rearranged, so that the story itself is embellished differently compared to previous versions, such as a turtle being bullied by children, and the King of the Sea Palace inviting Urashima Tarō in appreciation of the rescue of his daughter, the baby turtle, on the beach. That motif appears to have been influenced by the male dominant society at that time.

The Post-war Urashima Tarō by Dazai Osamu, who comically but satirically described his own view of the Urashima story, appears significantly different from previous versions. It reflects Dazai's anxiety for the future during and after the Second World War, but it contains his hope and the challenge toward the norms of society as 
well. Later, Matsutani Miyoko, a famous children's author, rewrote Urashima Tarō with Iwasaki Chihiro, as illustrator. So the Urashima story established a new genre of illustrated Japanese folktale book and this is now regarded as the archetype of the Urashima story, while currently many other versions of the Urashima story can be found all over Japan.

Therefore, the Urashima versions in Part Two are influenced by each previous version more or less, and absorbed the plot, motifs and the characters, but developed individually depending on the readership and social demands of the period in question. 


\section{PART FOUR}

\section{Conclusions}

\section{CHAPTER 8: Overall conclusions}

The present study examines fifteen significant historical versions of the Urashima story, which were analysed, compared, and interpreted in putative chronological order from the Asuka to Shōwa Periods. Also translations of thirteen of those were provided in Appendix 1. The four recent scholarly commentaries were surveyed in the literature review. Diagram 1 and 2 (linear development of the Urashima story from the Asuka to Heian Periods, and the Muromachi to Shōwa Periods respectively) are also provided at the ends of Parts Two and Three. In addition, a table of twenty-eight characteristics of key elements in the Urashima story is provided in this section in order to locate those elements clearly.

The results of the present thesis are summarised below, in respect of the aims that were outlined in the Introduction.

Aim (1) of this thesis was to trace how the Urashima story evolved from the earliest orally transmitted (i.e., pre-historic, pre-written) versions to modern times. As a result of analysis, it is surmised that before the Urashima story was recorded as written text, it was already a well-known oral tale, and more specifically, that it circulated and was transmitted among the ama group of coastal dwellers in Japan. Then, putatively, Iyobe no Umakai embellished and recorded this oral version, which is thought to have be recorded in the Asuka Period (593-710 CE) or earlier. This text, or a version closely based upon it, appeared as "Urashimako Den" that was included in Kojidan (1212-1215 $\mathrm{CE}$ ). Then, the second extant version of the Urashima story is that which was recorded in the Nara Period (early eighth century) in Tango no Kuni Fudoki Itsubun, and which is also believed to have been based on Iyobe's written version. However, it is a much embellished version compared to the first recorded version. Thereafter, as time went by, the Urashima tale developed along with the authors' writing skills and styles, which reflected the cultural development of the time. In addition, each Urashima version was developed from the previous versions, partly because of the increasing accessibility of the text. Also the Urashima story seems to have changed in part because of new developments in culture, including literary trends. Therefore, the Urashima story can be 
seen to have evolved with various modifications appropriate to the era, but was nevertheless transmitted in a discernibly unbroken succession from the pre-written version through to the modern version.

Aim (2) of the present study set out to identify why the story changed, and what influenced the authors to change the storyline from previous versions. The answers to these questions are closely linked to the evolution of the Urashima story. The authors did not simply reproduce the same or similar story from era to era. Rather, the authors accessed the previous versions of the Urashima story and modified or embellished it. The Urashima story was not always only a reflection of historical background and cultural development, but it also developed to contain lessons on morals and ethics. Arguably, this was in order to attract more readers, but another reason is that the historical background and culture in each period enormously influenced how each Urashima version evolved. For example, the idea of longevity and immortality that was very common during the Heian Period disappeared because the ideology in each period changed. Buddhism was a strong influence in the Muromachi Period, and so, not surprisingly, several Buddhist expressions can be seen in the version of this period.

In contrast, Buddhism was not as strong an influence in the Edo Period, and so these expressions do not appear as much, but rather the appearance of a new genre of humour and witty storyline that appealed to the new urban masses greatly influenced Edo Period versions of the story.

Aim (3) of the present study was to pinpoint how the Urashima Tarō story was passed on from generation to generation in Japan. It can now be summarised broadly that the purpose of each Urashima story differed. In the Nara Period, the purpose of the recorded version of the Urashima story was to record oral tales in writing. This was also related to the development of the writing system in the Nara Period; however, people in general had a low level of literacy at that time, so the purpose of the Urashima story then was to provide an entertaining tale for educated monks and aristocrats. Due to literary developments of the Heian Period, including the development of the kana writing system, the Urashima story appears to have become steadily more accessible by increasing numbers of people. In due course, the ehon (picture book) version also developed, in which the illustrations became integral to the story; and cultural developments in Buddhism and moral ethics also influenced greatly the way in which 
the story was transmitted in the Muromachi Period. As a result, people of that time were able to enjoy the story through reading it for themselves. It still contained tanka, one of the traditional Japanese literary characteristics, which allows readers to better understand the plot, so that all sorts of literary aspects were able to be combined into the Urashima story.

At the same time, the development of coloured woodblock printing, mass production of paper, commercialised publication of books, increased literacy rates, and the appearance of new genres of literature in the Edo Period together played a significant role in shaping new ways in which the tale was passed on to wider audiences.

Finally, aim (4) of the present research was to examine how Japanese people have chronologically interpreted and understood the story. This was identified as a reflection of the general view of people of the day, in other words, the Urashima story in the Meiji Period reflects the moral ethics and ideological beliefs held by people. Therefore aspects of the tale may be hard for people of other generations to comprehend. The significance of the motif of Urashima opening the jewelled box and smoke coming out and turning him into an old man may be largely lost to post-war Japanese people, but it was undoubtedly an obvious concept for people of the Heian and Muromachi Periods because of word play on tama ('soul' and 'jewel').

Likewise, the important motifs of Mt. Hōrai, Tokoyo, the place name of Tsutsukawa, the five-coloured turtle, crane and turtle, golden elixir and immortals, tanka and its technique of double entendre, chiastic reversal in the place name of Mizunoe and Suminoe/Sumiyoshi are all completely lost in the Meiji to the Shōwa Period versions of the Urashima story. Because these once very important concepts and ideological types of motifs do not hold as much importance as they used to, it was no longer relevant to include these in the Urashima story.

In addition, one of the valuable findings from this thesis is the identification of the orality-based folktale's transformation into a literary based folktale: particularly the identification of Otogizōshi as a major turning point in the Urashima story. The Urashima story version in Otogizōshi, Urashima Tarō, is regarded as a prototype of the modern Urashima story and it also influenced Iwaya Sazanami’s Urashima story, which became the standardised popular literary version in Japan. Until Urashima Tarō in 
Otogizōshi was written, the pre-written orality-based story of the Urashima tale existed, which included traditional Japanese techniques of orality, tanka, word play, satirical and witty song exchange, and double entendre among others. Possibly, the people of that time could understand this orality based reading material and techniques, and so they enjoyed the story as orality-based folklore even though it was in written form, the purpose of which was merely to record the orality based folktale.

However, there was very limited access to books until the popularisation of picture books, improvement of printing techniques such as wood printing, mass production of paper, and the improvement of the literacy level of common people enabled greater accessibility from around the sixteenth century. Because of these changes due to cultural developments, people started to lose the sense of orality in storytelling, and seem to have almost lost the ability to understand the meaning of the traditional orality-based folklore. Therefore, people nowadays try to understand Otogizōshi as written material and literature in the Muromachi Period.

The Urashima story was once a common oral folktale which developed into literature for young children, and it also became one of the standardised written stories in Japan after Iwaya's book and the Ministry of Education Designated text book were published, finalising the written version. Because of this, the meaning of the Urashima story has changed drastically: it has become only a very simplified folktale, and Japanese people in general nowadays do not completely understand the meaning behind the orality-base of the Urashima story. Therefore the Otogizōshi version is here regarded as the last orality-based traditional version of the folktale of Urashima.

Following are more specific details of the linear development of the Urashima story and its chronological evolution, and its interpretation. Before the Urashima story was recorded as text, the putative Urashima story was believed to have been a wellknown oral tale among the ama group of coastal dwellers in Japan, who are surmised to have originated around Lake Dongting, in north-eastern Hunan province of China, in prehistoric times. However, there is a time discrepancy between the recording of the tale in writing and the earliest extant appearance of that version in print. Some scholars seem to have unquestioningly assumed that "Urashimako Den" was recorded much later than the Asuka Period. The present study examined the age of the vocabulary and expression in "Urashimako Den" in the Kojidan version, and tentatively concludes as a 
result that this version is the earliest extant written version of the Urashima story. Moreover, one of the motifs was the taking of a golden elixir in order to live longer as if immortal, which was rarely seen in stories by the Heian Period (974-1185 CE), due to its known toxicity, suggesting that this motif dates to an earlier period. Also Mt. Hōrai appears in this version, while ancient Japanese belief in Tokoyo, the everlasting world, does not, again suggesting that this story was influenced by earlier traditional Chinese ideology rather than Japanese beliefs.

The author in "Urashimako Den" is not identified, but Iyobe no Umakai may be the putative author of "Urashimako Den" because of the historical records of his role as an administrator, his estimated year of death, and his knowledge and skills in writing. In Tango no Kuni Fudoki Itsubun in the Nara Period (710-784 CE) it states that "Iyobe's recorded version said...", so although some scholars believe that Iyobe is the author of this version also, it is unlikely that it was recorded by Iyobe himself, but was based closely on his (now lost) written version. In addition, this Itsubun version is very long, well structured, and has lots of embellishments compared to "Urashimako Den" in Kojidan.

Around the same time that Tango no Kuni Fudoki Itsubun was recorded (early eighth century, post $713 \mathrm{CE}$ ), Nihonshoki was published in $720 \mathrm{CE}$ as the official historical chronicle of Japan, and this also contained the Urashima story. However, this version is very brief and concise as though it were quoted from another Urashima version. It is even recorded here as “語在別巻” (there is another volume of this story in existence), so we know that there must have been a version recorded prior to $720 \mathrm{CE}$. Again, it is unclear whether or not this re-exisiting version was that allegedly recorded by Iyobe.

In Manyōshū, the Urashima poem was recorded by Takahashi no Mushimaro. The motif and characters are slightly different from "Urashimako Den", Tango no Kuni Fudoki Itsubun and the even shorter version of the Urashima story in Nihonshoki. The main character of Shimako dies at the end of the story, and there is no appearance of the character of the turtle. It is surmised that Mushimaro might have been able to access previous versions of the Urashima story and that he attempted to create his own version of the Urashima narrative story in Manyōsh $\bar{u}$. This version focuses on motifs related to Japanese deities and Sumiyoshi Grand Shrine, and is regarded as less influenced by 
Buddhist or ancient Chinese ideology. Instead, it seems that the group of ama people, who believed that their ancestors were a type of snake-like creature living under the sea called "tsutsu", were a stronger influence in this version.

While "Tsutsukawa" was added in Manyōsh $\bar{u}$, the place names of "Mizunoe" and "Suminoe" appear very commonly in the Urashima story. The present study has identified these two place names as related through the oral technique of chiastic reversal. Therefore it could be concluded that the Manyōsh $\bar{u}$ version of the Urashima story was more focused on traditional Japanese thought than directly developed from the linear versions of previous Urashima stories. Thus the Manyōshū version is here deduced to be an independent version, rather than a direct linear development from previous recorded versions.

Another "Urashimako Den" version can be found in Gunshoruijū dating from 1819; however, this version is also estimated to have been recorded by $820 \mathrm{CE}$ in the Heian Period (794-1185 CE). This version is similar to the aforementioned "Urashimako Den" in Kojidan, although characters and expressions are different, and it is analysed that this version cannot be earlier than "Urashimako Den" in Kojidan. Also Gunshoruijū contains another version of the Urashima story called "Zoku Urashimako Denki," which is believed to have been recorded in 920 CE and 932 CE. This version has a very similar storyline to the "Urashimako Den" versions, and is a mixture of an embellished version of "Urashimako Den" in Gunshoruiju, and classical Chinese poems in the style of “seven words and twenty-two rhymes (七言二十二韻)".

Two other versions of the Urashima stories are recorded in Fusōryakki (after 1094 CE) but there are no titles to these two stories. The first text is believed to be a simplified and modified version of Tango no Kuni Fudoki Itsubun, and the second text is almost identical with "Urashimako Den" in Kojidan, except for a few differences in expression and vocabulary. Therefore, it is deduced that these versions were recorded after the "Urashimako Den" in Kojidan, and Gunshoruiju versions of the Urashima stories. The author's name is not recorded and the putative author cannot be identified. However, what this tells us indirectly is that the Urashima story was certainly popular in the Heian Period; otherwise, it is unlikely to have been recorded as "Urashimako Den", “Zoku Urashimako Den” and in two texts in Fusōryakki. 
The Urashima story appears in the Muromachi Period (1392-1573 CE) as "Urashima Tarō" in Otogizōshi. The story title and the main character name of Urashima Tarō and the key motif of the Sea Palace (ry ūgūjōo) appear for the first time in this version. This version is not only influenced by previous versions, but also by Muromachi cultural growth and development, particularly Buddhist expression and tanka, as well as the inclusion of wit, satire, double entendre, punning and word play, the true intention of honne and duty of tatemae. The hidden message in the tanka as a key element to finding the true message of the Urashima story in Otogizōshi was also examined, and it was revealed that the treasure box (tamatebako) that contains the white smoke (tamashii) was a wordplay on 'jewel' and 'soul', which are both known as tama. The Princess put Urashima's soul in the box as a souvenir on purpose because she knew that Urashima would eventually open the box, and she could then be with him again by forever changing their figures into a turtle and crane, symbolic creatures of longevity, and enshrining him as Urashima Myōjin (god). For the first time the story has a happy ending, which goes on to influence Iwaya Sazanami's Urashima Tarō in the Meiji Period (1868-1912). The latter gives an equivocal ending: Urashima Tarō suddenly becoming an old man but living happily ever after! This part may have been mistakenly interpreted by Iwaya.

There are many 'firsts' in this version because of the literary development during the Muromachi Period. The simply recorded version seems to change into a well structured richly expressed piece of literature compared to previous versions.

Further development of the Urashima story can be seen in the Edo Period (1603$1867 \mathrm{CE}$ ) as influenced by urbanised cultural and technological developments such as woodblock printing, mass production of paper,increased commerce, higher literacy levels, liberalism and the appearance of new literary genres. Mukashibanashi Urashima Jijī was composed by Ryūtei Tanehiko, one of the gesaku writers of, who used his imagination freely and described the Urashima story as if it was a parody, but did not forget to insert the obvious moral lesson. As a result it sent a clear message and became a popular story of townspeople, so much so that it also appeared in theatre.

Tanehiko even describes the ryūgūjo (the Sea Palace) as under the sea for the first time, and it becomes a prototype for the Urashima story and the place of the Sea Palace in the contemporary Japanese tale. 
The children's story writer Iwaya Sazanami may have been influenced by previous versions of the Urashima story, particularly Urashima Tarō in Otogizōshi. He wrote the Nippon Mukashibanashi series in 1864-1896 that became popular tales in Japan of that time, with Urashima Tarō featuring as one of them. The Meiji Educational Reform required textbook compilation, and Iwaya was appointed as one of the editors. For this purpose he needed to change the Urashima story into a concise short story in children's story book style so that the young readership could follow the entire thread of the tale. As a result, the Urashima story featured in the Ministry of Education Designated Textbook second and third editions for thirty-nine years throughout the Meiji, Taishō and Shōwa Periods. This could be the reason why the Urashima story became so popular in Japan and the contemporary version so well-known. However, there is still no explanation in relation to the white smoke and the moral lesson this conveys.

The Urashima story was also influenced and changed due to changes in social circumstances. For example, the key motifs of Mt Hōrai, Tokoyo, immortals and longevity in the Asuka, Nara and Heian Period are not seen in the contemporary versions at all because the historical background and the moral ethics have changed over time and were no longer relevant.

One of the famous twentieth-century authors, Dazai Osamu, wrote a parody of the Otogizoshi, including one of the stories called "Urashima san". The book reflects on Dazai's anxiety for the future due to its publication during the Second World War. It seems as though he was challenging society, democratic liberalism, and the lack of criticism of literature through "Urashima san." So in this case the target audience is not just for children but for everyone. His positive message can be seen when Urashima turns into a grey-haired old man, which Dazai obviously thought was not a bad or undesirable ending, as there is no mention that Urashima spends a miserable time because of his age. In this regard this version of the Urashima story is quite different from others, particularly previous versions.

More recently, Matsutani Miyoko, an author of children's literature, wrote the book Urashima Tarō in 1967. It was an illustrated story book for children and the storyline is quite similar to the Ministry of Education Designated textbook version. Notably, Matsutani's book contains the same key motifs: the five-coloured beautiful 
turtle and three-hundred years of elapsed time, the main character name of Urashima Tarō, ryūgūjō being under the sea, and expressions clearly derived from Tango no Kuni Fudoki Itsubun, Otogizōshi, and Mukashibanashi Urashima Jijī respectively. This version also contains the apparent moral lesson of "rescue from bullying and receive the reward of an invitation to the Palace." Nevertheless, it is hard to understand the main moral lessons, especially the relation of the white smoke to the aging of Urashima Tarō. The significance of this was not immediately obvious, meaning that explanation was required to spell out that the smoke was Urashima's age. This is because contemporary Japanese people are no longer as familiar with word play as seen in Otogizōshi in the Muromachi Period, and the moral lessons of the traditional Urashima tale was no longer clear to most readers, particularly post war. Also, the place names are no longer significant in this version, so neither 'Tango' nor 'Mizunoe' are mentioned in Matsutani's version.

As can be seen from this thesis, the Urashima story has generally developed linearly; some stories were developed on the basis of previous versions but differently compared to other versions, such as Manyōshū and "Urashima san" in Otogizōshi by Dazai. The audience also changed from the educated, who understood the recorded version in the Nara and Heian Periods, to a new genre due to the influence of cultural development during the Muromachi Period, and the introduction of mass production and woodblock printing that enabled more people to access books in the Edo Period than previously. Also, the appearance of the new genre of gesaku made it possible to change the Urashima story in the Edo period. The audience then shifted from the townspeople to children due to a higher literacy level and educational reforms during the Meiji Period, making the Urashima story even more popular than before and standardising the Urashima Taro thread into the contemporary version. Finally, the late Shōwa Period illustrated books of Urashima Tarō for children concluded the modern versions of the Urashima story that were influenced by Tango no Kuni Fudoki Itsubun (post 713 CE), "Urashima Tarō" in Otogizōshi in the Muromachi Period (1392-1573 CE), and Iwaya's Urashima Tarō version. 
Table 1. Key characteristics and common storylines in the Urashima stories.

Periodizasion, according to Kodama, Kōta (1995: unnumbered content page):

$\begin{array}{ll}\text { 350-645 } & \text { Genshi and Asuka Period } \\ \text { 645-794 } & \text { Asuka and Nara Period } \\ \text { 794-1192 } & \text { Heian Period } \\ 1192-1334 & \text { Kamakura Period } \\ 1334-1600 & \text { Muromachi Period } \\ 1601-1867 & \text { Edo Period } \\ 1868-1912 & \text { Meiji Period } \\ 1912-1926 & \text { Taishō Period } \\ 1926-1989 & \text { Shōwa Period }\end{array}$


Part 1: No. 1-8, and Part 2: No. 9-15

\begin{tabular}{|c|c|c|c|c|c|c|c|c|c|c|c|c|c|c|c|}
\hline 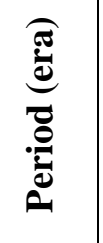 & 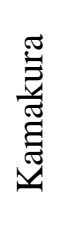 & 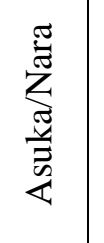 & 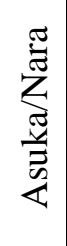 & 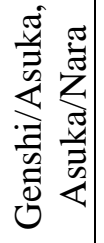 & $\frac{8}{i}$ & $\frac{8}{i}$ & . & $\frac{.0}{\frac{0}{0}}$ & $\frac{8}{i}$ & $\frac{8}{i}$ & 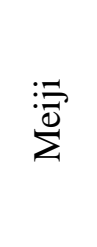 & \multicolumn{2}{|c|}{ 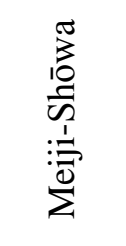 } & 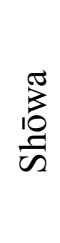 & 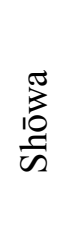 \\
\hline 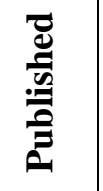 & $\begin{array}{l}\frac{n}{d} \\
\frac{1}{d} \\
\stackrel{d}{d}\end{array}$ & $\begin{array}{l}\frac{m}{\pi} \\
\frac{1}{0} \\
0\end{array}$ & $\stackrel{\overbrace{}}{\approx}$ & $\begin{array}{l}\text { ò } \\
\text { م⿱ } \\
\text { ò }\end{array}$ & $\stackrel{\infty}{\infty}$ & $\stackrel{\infty}{\infty}$ & $\frac{+}{8}$ & 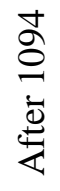 & 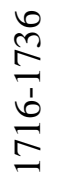 & $\underset{\infty}{\infty}$ & \begin{tabular}{l}
$\stackrel{2}{\infty}$ \\
\multirow{1}{1}{} \\
$\stackrel{2}{+}$ \\
$\infty$
\end{tabular} & \multicolumn{2}{|c|}{ 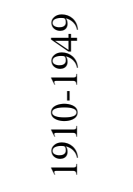 } & $\stackrel{n}{2}$ & 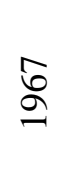 \\
\hline 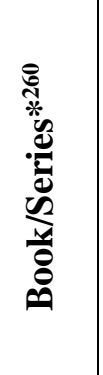 & 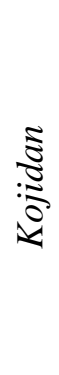 & 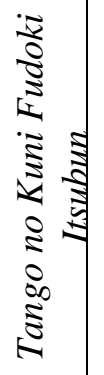 & 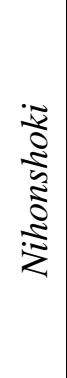 & 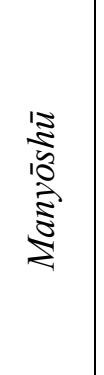 & 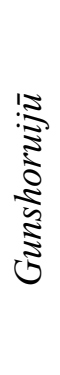 & 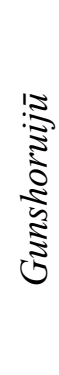 & 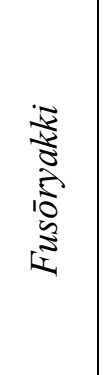 & 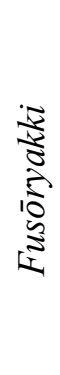 & $\begin{array}{l}\tilde{5} \\
10 \\
10 \\
.00 \\
0 \\
0 \\
0 \\
*\end{array}$ & 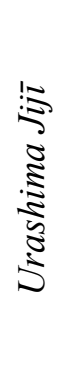 & 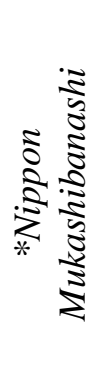 & \multicolumn{2}{|c|}{ 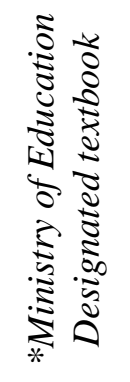 } & $\begin{array}{l}\cdot \tilde{5} \\
\bar{w} \\
\cdot \tilde{N} \\
00 \\
0 \\
0 \\
0\end{array}$ & $\begin{array}{l}10 \\
\vdots \\
0 \\
0 \\
.5 \\
5 \\
5 \\
5\end{array}$ \\
\hline 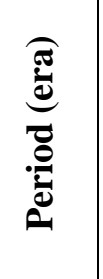 & 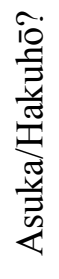 & 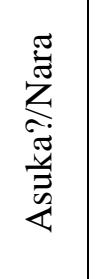 & 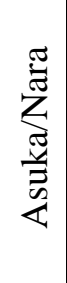 & 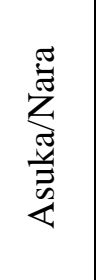 & 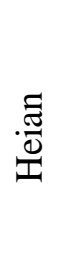 & $\frac{\mathbb{\pi}}{\mathbb{d}}$ & 宽 & . & 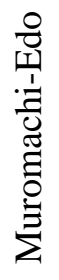 & $\frac{8}{10}$ & $\frac{\bar{\sigma}}{\Sigma}$ & 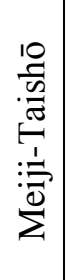 & 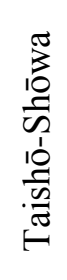 & 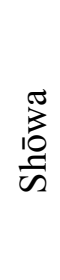 & 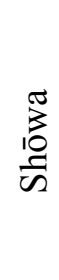 \\
\hline 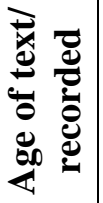 & 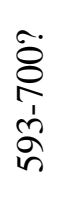 & $\begin{array}{l}\stackrel{\ddot{n}}{\nabla} \\
\dot{0}\end{array}$ & ్ㅗㅇ & 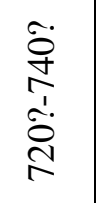 & $\begin{array}{l}\hat{ᄋ} \\
\text { ஸे } \\
\vdots \\
\text { م. }\end{array}$ & 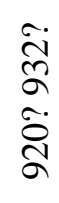 & 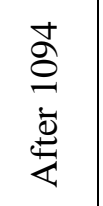 & 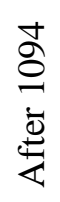 & 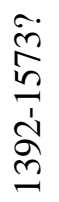 & $\underset{\infty}{\infty}$ & ஓ & $\begin{array}{l}\frac{a}{\sigma} \\
\bar{\sigma} \\
\frac{1}{a}\end{array}$ & $\frac{\stackrel{\sigma}{\sigma}}{\frac{\infty}{\sigma}}$ & $\stackrel{n}{\text { g }}$ & ڤ̊ \\
\hline & & & $\frac{\vec{z}}{\tilde{n}}$ & $\begin{array}{l}\mathscr{\Xi} \\
\Xi \\
\Xi\end{array}$ & & $\therefore$ & & & & & & $\overrightarrow{\widetilde{N}}$ & $\vec{m}$ & & \\
\hline 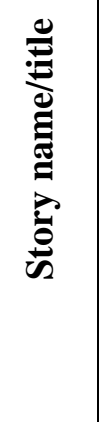 & 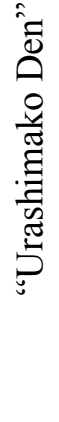 & $\begin{array}{l}\stackrel{0}{\Xi} \\
\text { Zे } \\
\text { z }\end{array}$ & 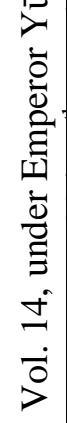 & 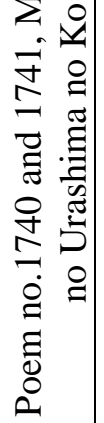 & 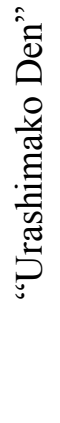 & 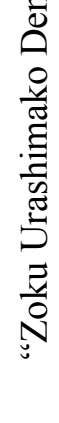 & 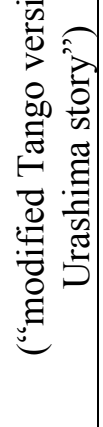 & 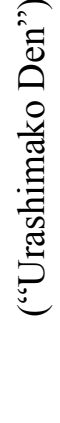 & 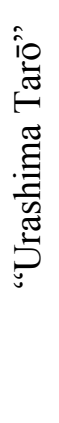 & 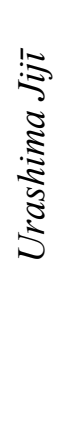 & 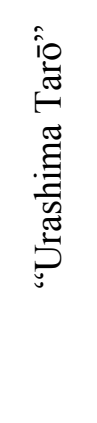 & 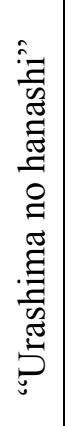 & 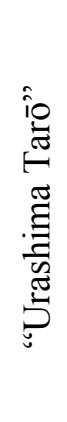 & 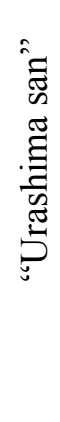 & 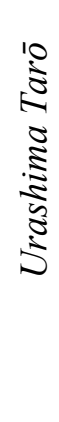 \\
\hline$\stackrel{\dot{Z}}{Z}$ & - & $N$ & m & $\nabla$ & in & b & $n$ & $\infty$ & $a$ & $\stackrel{ }{ }$ & 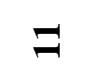 & 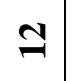 & $m$ & \pm & $n$ \\
\hline
\end{tabular}

$260 *$ means a series of books but published an individual story 


\begin{tabular}{|c|c|c|c|c|c|c|c|c|c|c|c|c|c|c|c|}
\hline 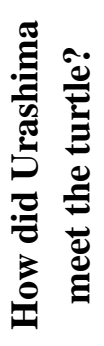 & 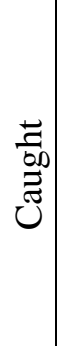 & $\begin{array}{l}\overrightarrow{\vec{z}} \\
\text { b0 } \\
\overrightarrow{\tilde{U}}\end{array}$ & 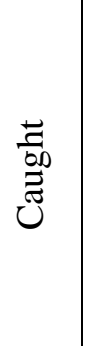 & $\vdots$ & $\begin{array}{l}\overrightarrow{\vec{E}} \\
\overrightarrow{00} \\
\vec{\Xi} \\
\tilde{U}\end{array}$ & $\begin{array}{l}\vec{E} \\
\text { Do } \\
\overrightarrow{\tilde{U}} \\
\end{array}$ & $\begin{array}{l}\overrightarrow{\vec{E}} \\
\text { b0 } \\
\vec{E} \\
\tilde{U}\end{array}$ & $\begin{array}{l}\overrightarrow{\vec{E}} \\
\overrightarrow{00} \\
\vec{E}\end{array}$ & $\begin{array}{l}\overrightarrow{\vec{z}} \\
0 \\
\overrightarrow{0} \\
\vec{U}\end{array}$ & 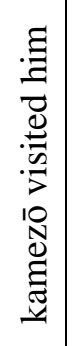 & 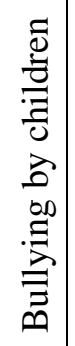 & 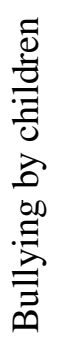 & 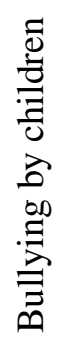 & 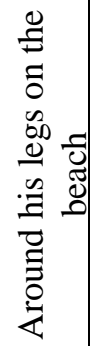 & $\stackrel{\infty}{\stackrel{\infty}{\Xi}}$ \\
\hline$\underset{\uparrow}{\stackrel{\Xi}{\rightleftarrows}}$ & 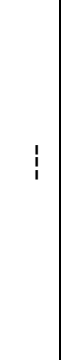 & 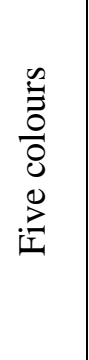 & $\stackrel{\infty}{\infty}$ & $\vdots$ & 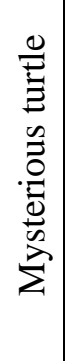 & 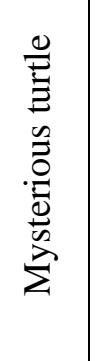 & $\frac{.00}{\infty}$ & $\vdots$ & $i$ & 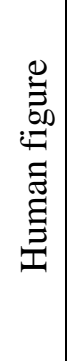 & 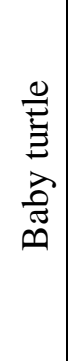 & 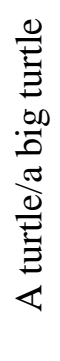 & 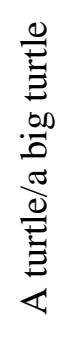 & 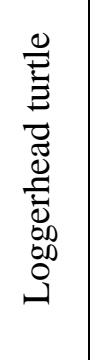 & 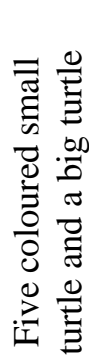 \\
\hline$\stackrel{巳}{E}$ & $>$ & $>$ & $>$ & $!$ & $>$ & $>$ & $>$ & $>$ & $>$ & $>$ & $>$ & $>$ & $>$ & $>$ & $>$ \\
\hline 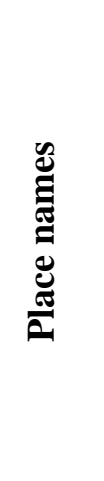 & 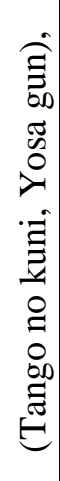 & 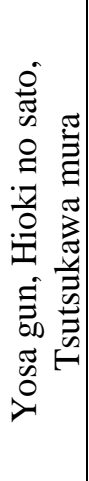 & 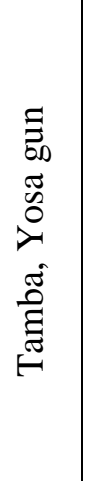 & 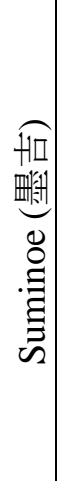 & 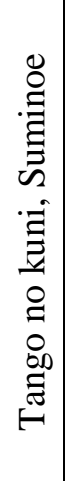 & 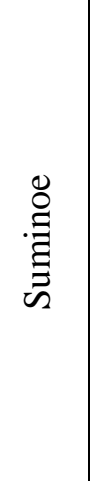 & 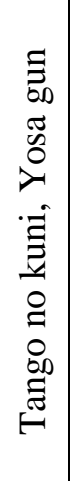 & 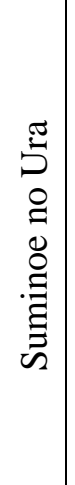 & 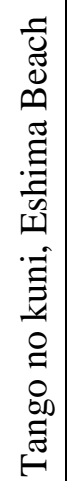 & 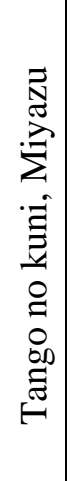 & 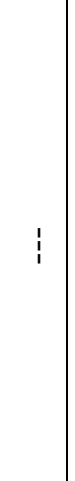 & $\dot{1}$ & $\mid$ & 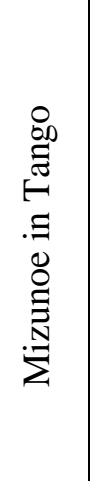 & 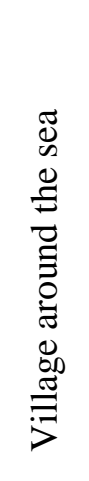 \\
\hline 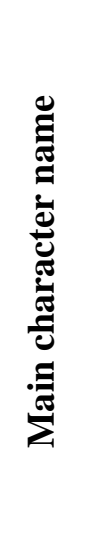 & 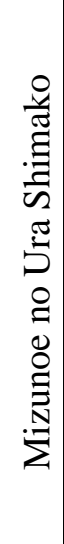 & 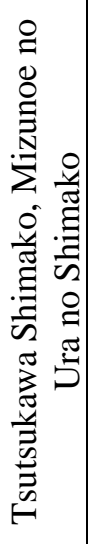 & 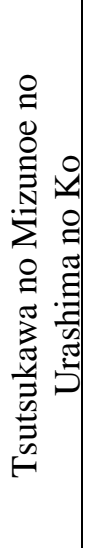 & 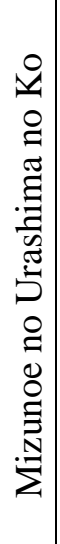 & 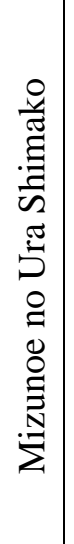 & 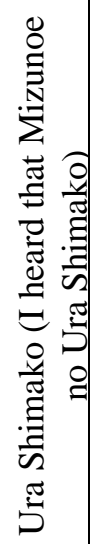 & 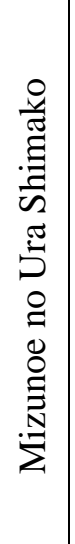 & 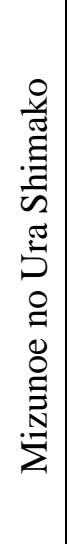 & 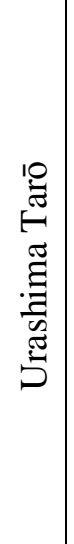 & 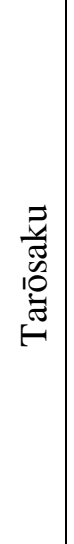 & 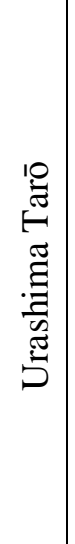 & 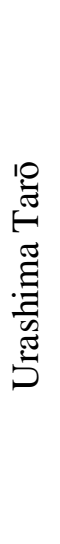 & 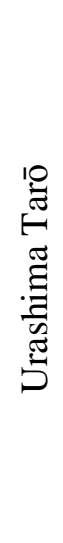 & 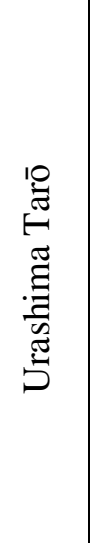 & 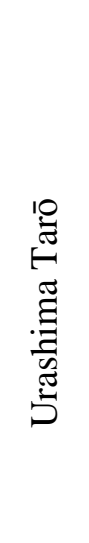 \\
\hline$\dot{\mathbf{Z}}$ & - & $\sim$ & $\infty$ & $\nabla$ & in & b & n & $\infty$ & $a$ & $\stackrel{\theta}{ }$ & $\Xi$ & $\mathcal{I}$ & $m$ & \pm & 10 \\
\hline
\end{tabular}




\begin{tabular}{|c|c|c|c|c|c|c|c|c|c|c|c|c|c|c|c|}
\hline 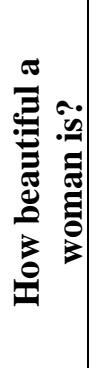 & 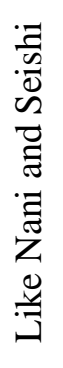 & 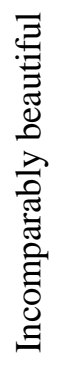 & 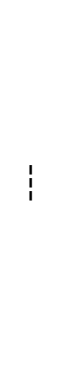 & 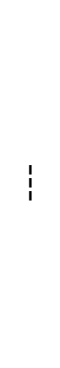 & 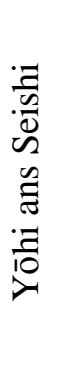 & 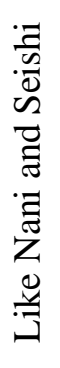 & 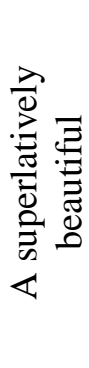 & 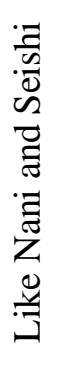 & 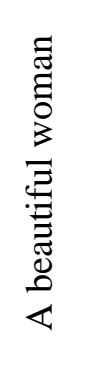 & $\begin{array}{l}8 \\
\frac{8}{0} \\
\frac{0}{0} \\
0 \\
0 \\
\frac{1}{3} \\
0 \\
\frac{0}{0} \\
\frac{1}{0} \\
0 \\
\end{array}$ & 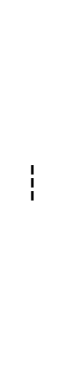 & 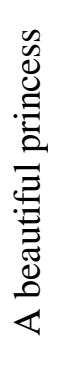 & 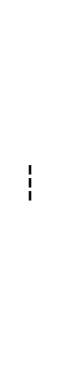 & 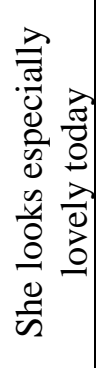 & 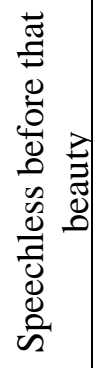 \\
\hline 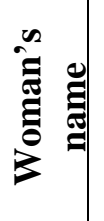 & 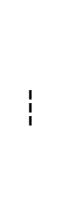 & 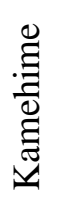 & $\mid$ & 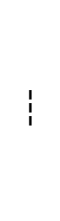 & 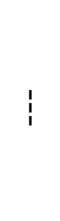 & 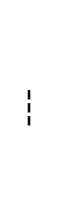 & 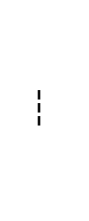 & $\mid$ & $\mid$ & 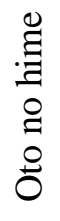 & 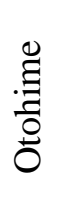 & 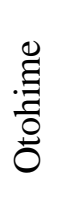 & $\begin{array}{l}\stackrel{\mathscr{\Xi}}{\Xi} \\
\stackrel{\Xi}{0} \\
0\end{array}$ & 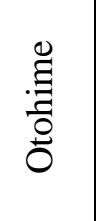 & 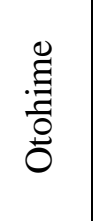 \\
\hline 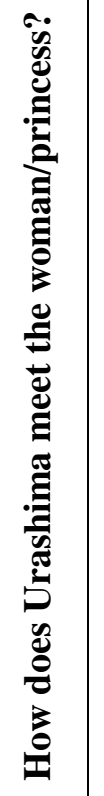 & 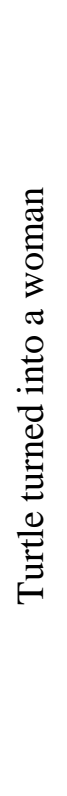 & 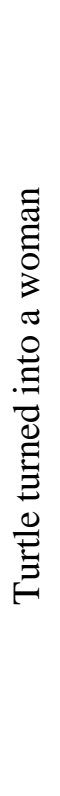 & 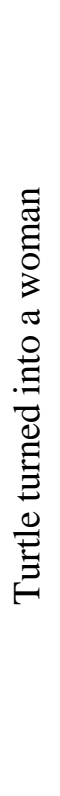 & 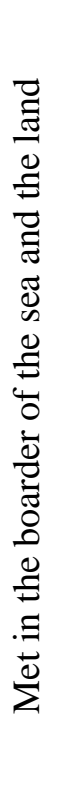 & 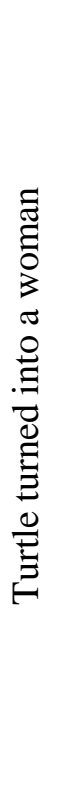 & 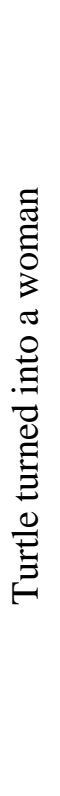 & 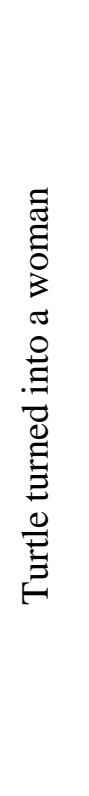 & 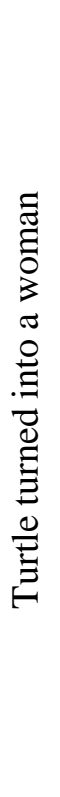 & 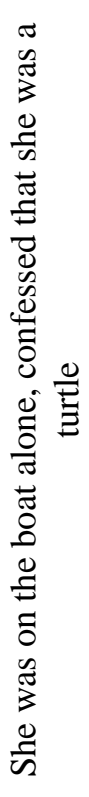 & 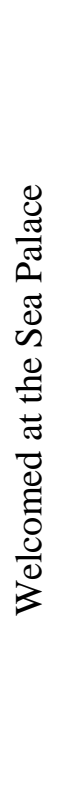 & 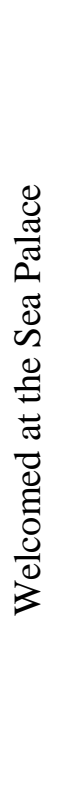 & 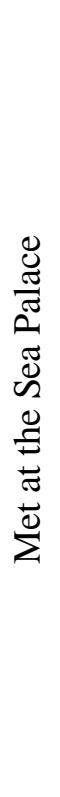 & 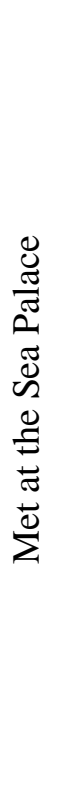 & 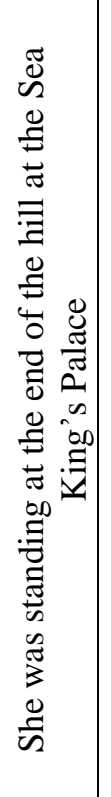 & 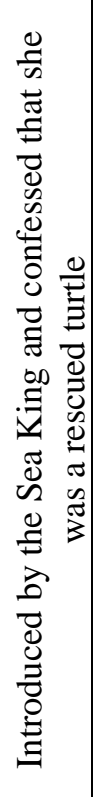 \\
\hline 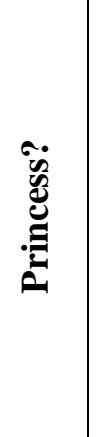 & $\begin{array}{l}\frac{\tilde{\Xi}}{\tilde{\pi}} \\
\sum\end{array}$ & 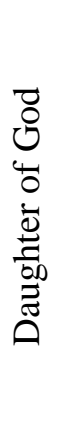 & $!$ & 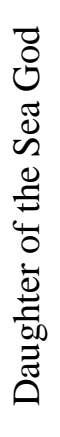 & $\frac{\bar{\nabla}}{\tilde{\pi}}$ & $\frac{\tilde{\Xi}}{\stackrel{\tilde{J}}{\pi}}$ & 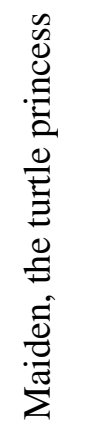 & $\frac{\sqrt[\Xi]{\tilde{J}}}{\stackrel{\tilde{\pi}}{\Sigma}}$ & $\mid$ & $>$ & $>$ & $>$ & $>$ & $>$ & 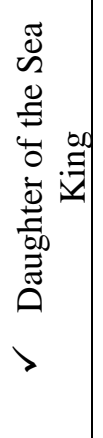 \\
\hline 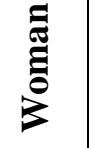 & $\mid$ & $\mid$ & $\mid$ & 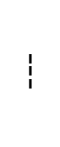 & 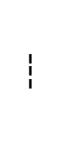 & $!$ & $!$ & $!$ & $\vdots$ & 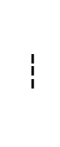 & $\vdots$ & $>$ & $>$ & ! & $!$ \\
\hline$\dot{\mathbf{Z}}$ & - & $N$ & $m$ & $\nabla$ & in & $b$ & $r$ & $\infty$ & $a$ & 으 & $\approx$ & $\beth$ & 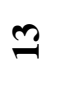 & $\Xi$ & 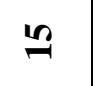 \\
\hline
\end{tabular}




\begin{tabular}{|c|c|c|c|c|c|c|c|c|c|c|c|c|c|c|c|}
\hline 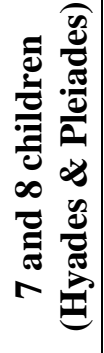 & 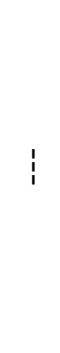 & $>$ & $\mid$ & 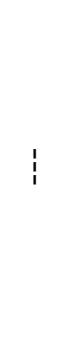 & 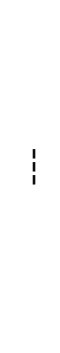 & 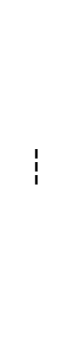 & $>$ & 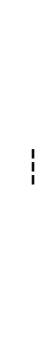 & 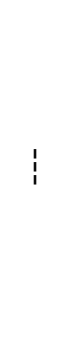 & 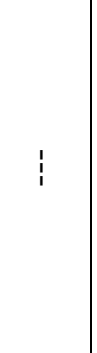 & $\mid$ & $\mid$ & 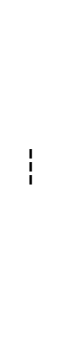 & $\mid$ & 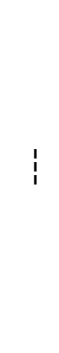 \\
\hline 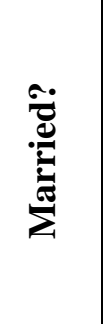 & $\mid$ & $>$ & $>$ & $>$ & $>$ & $>$ & 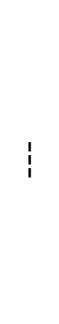 & $\mid$ & $>$ & 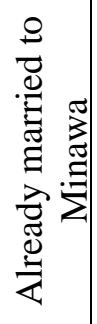 & 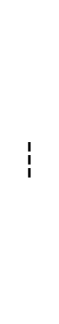 & $\mid$ & $\mid$ & 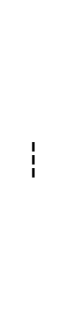 & 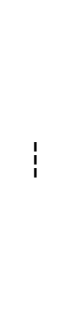 \\
\hline 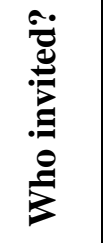 & 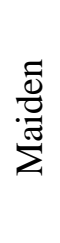 & 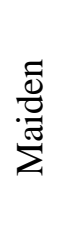 & a. & $\begin{array}{l}\text { ञే } \\
\text { ص }\end{array}$ & $\begin{array}{l}\frac{\mathbb{0}}{0} \\
\frac{\pi}{\Sigma}\end{array}$ & $\begin{array}{l}\frac{\mathbb{0}}{\pi} \\
\frac{\pi}{\pi}\end{array}$ & $\begin{array}{l}\frac{\bar{d}}{. \pi} \\
\sum\end{array}$ & $\begin{array}{l}\frac{\mathbb{d}}{\tilde{\pi}} \\
\sum\end{array}$ & $\begin{array}{l}\frac{\mathbb{0}}{\tilde{\pi}} \\
\sum\end{array}$ & 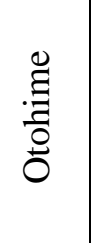 & 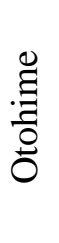 & $\underset{E}{\stackrel{D}{E}}$ & $\underset{E}{\stackrel{D}{\Xi}}$ & 莺 & $\frac{\infty}{\Xi}$ \\
\hline 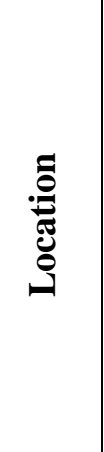 & 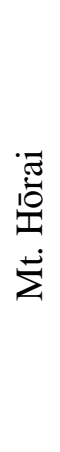 & 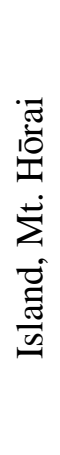 & $\begin{array}{l}\tilde{D} \\
\infty \\
\mathscr{\Xi} \\
\Xi \\
\Xi\end{array}$ & $\begin{array}{l}\stackrel{0}{0} \\
\frac{0}{0} \\
\ominus\end{array}$ & 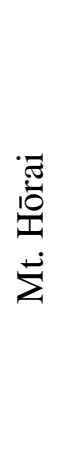 & $\begin{array}{l}\text { 픔 } \\
\text { I0 } \\
\dot{\Sigma} \\
\dot{\Sigma}\end{array}$ & 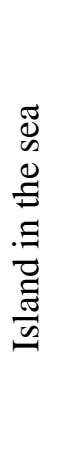 & 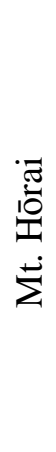 & 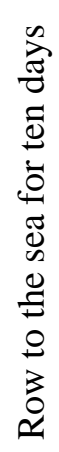 & 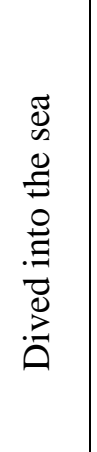 & 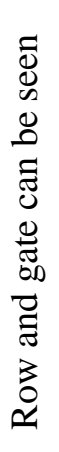 & 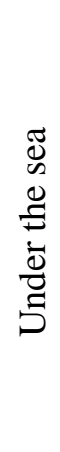 & 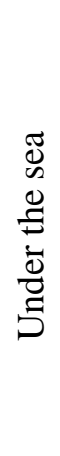 & 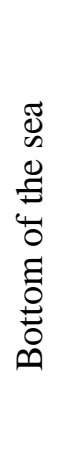 & 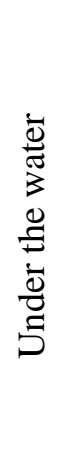 \\
\hline 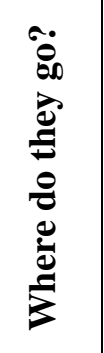 & 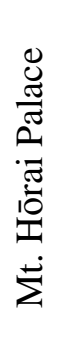 & 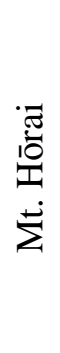 & 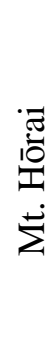 & 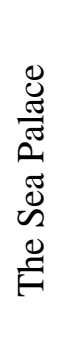 & 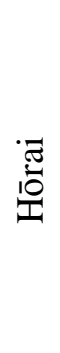 & 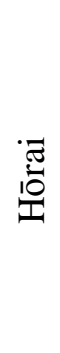 & 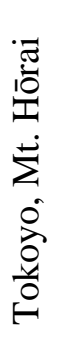 & 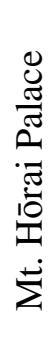 & 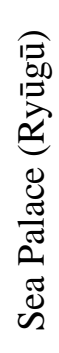 & 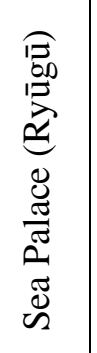 & 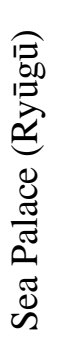 & 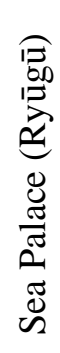 & 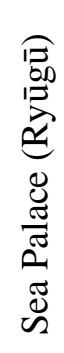 & 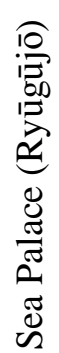 & 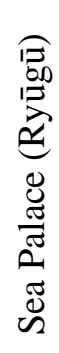 \\
\hline$\dot{z}$ & - & $N$ & $m$ & $\nabla$ & in & 6 & $r$ & $\infty$ & $a$ & $\stackrel{\theta}{ }$ & $=$ & $\mathcal{I}$ & $\theta$ & \pm & 10 \\
\hline
\end{tabular}




\begin{tabular}{|c|c|c|c|c|c|c|c|c|c|c|c|c|c|c|c|}
\hline 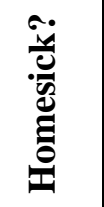 & $>$ & $>$ & $\mid$ & $>$ & $>$ & $>$ & $>$ & $>$ & $>$ & 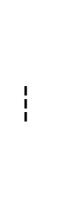 & $>$ & $\begin{array}{l}\bar{D} \\
\stackrel{0}{0} \\
\oplus \\
>\end{array}$ & 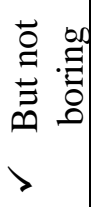 & $>$ & $>$ \\
\hline 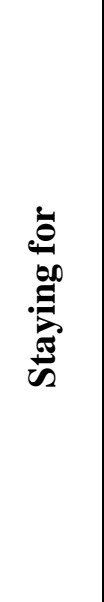 & 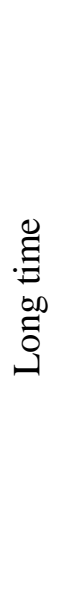 & 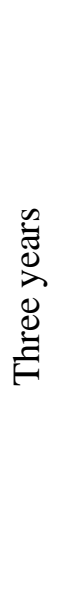 & $\vdots$ & 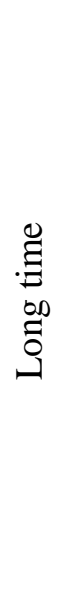 & 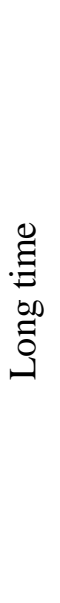 & $\begin{array}{l}\stackrel{\Xi}{\Xi} \\
. \Xi \\
00 \\
\tilde{0} \\
.\end{array}$ & $\vdots$ & 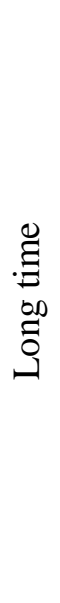 & 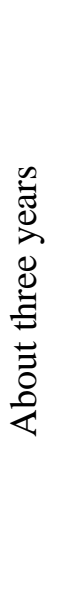 & 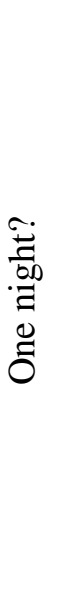 & 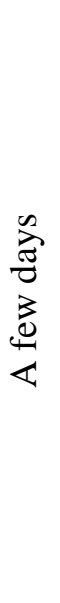 & $\vdots$ & $\vdots$ & 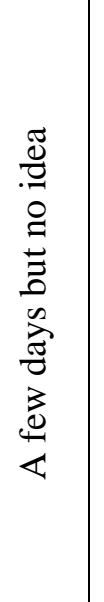 & 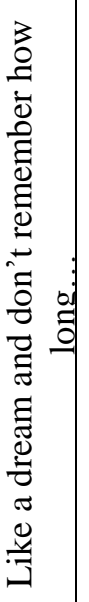 \\
\hline 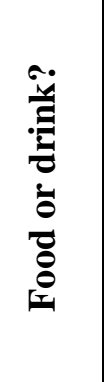 & 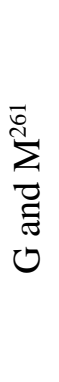 & 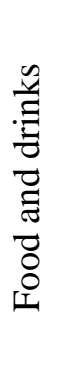 & $\mid$ & $\mid$ & 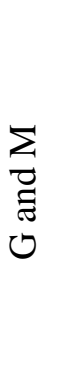 & $\begin{array}{l}\sum_{\Xi} \\
\stackrel{\Xi}{\Xi} \\
0\end{array}$ & 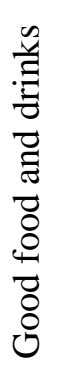 & 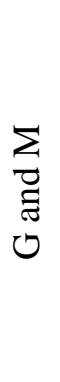 & $\vdots$ & $\frac{\tilde{J}}{\tilde{g}}$ & 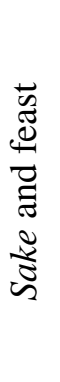 & 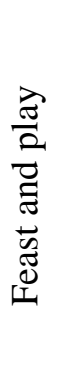 & 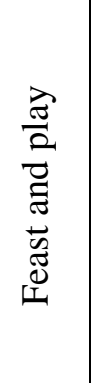 & 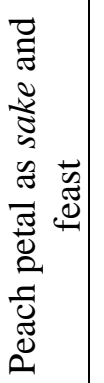 & 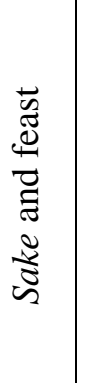 \\
\hline 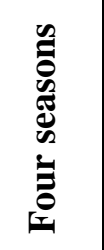 & $\vdots$ & $\vdots$ & $\mid$ & $\mid$ & 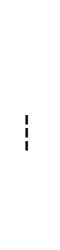 & $\mid$ & $!$ & 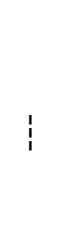 & $>$ & 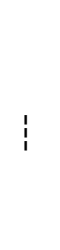 & $>$ & 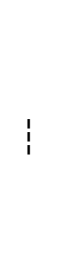 & $\vdots$ & $\vdots$ & $>$ \\
\hline 彎 & $>$ & $>$ & $\mid$ & $\frac{\ddot{\Xi}}{\frac{\tilde{\sigma}}{\sigma}}$ & $>$ & $>$ & $>$ & $>$ & $>$ & $>$ & $>$ & $\mid$ & $\mid$ & $\mid$ & $>$ \\
\hline$\stackrel{\dot{Z}}{\mathbf{Z}}$ & - & $N$ & $n$ & $\nabla$ & in & b & $r$ & $\infty$ & $a$ & 음 & 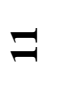 & 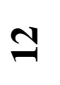 & 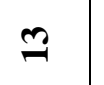 & $\Xi$ & $n$ \\
\hline
\end{tabular}

${ }^{261}$ Golden elixir and milk of limestone, miraculous infusions and sake 


\begin{tabular}{|c|c|c|c|c|c|c|c|c|c|c|c|c|c|c|c|}
\hline 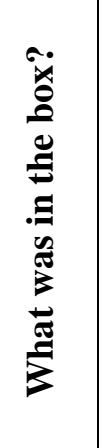 & $\begin{array}{l}\frac{a}{0} \\
\frac{0}{0} \\
\frac{\omega}{2} \\
\bar{z} \\
\end{array}$ & 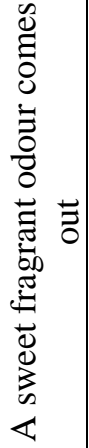 & $i$ & $\begin{array}{l}\frac{0}{0} \\
\frac{0}{0} \\
.0 \\
\frac{0}{3}\end{array}$ & 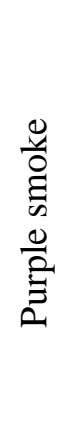 & $\begin{array}{l}\frac{a}{0} \\
\frac{0}{0} \\
\frac{0}{2} \\
\frac{0}{2} \\
0\end{array}$ & 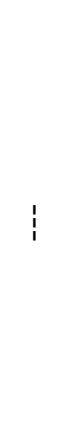 & 1 & 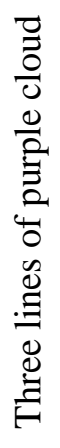 & 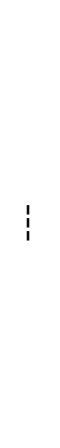 & 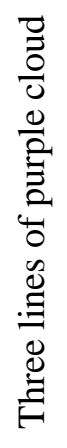 & 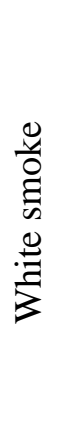 & 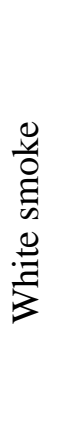 & 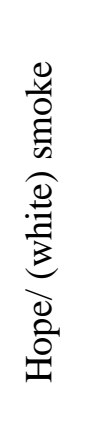 & 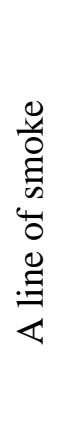 \\
\hline 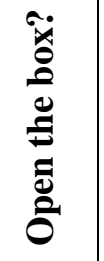 & $>$ & $>$ & $\mid$ & $>$ & $>$ & $>$ & $\vdots$ & $>$ & $>$ & $\mid$ & $>$ & $>$ & $>$ & $\mid$ & $>$ \\
\hline 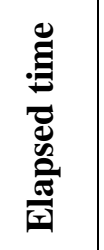 & 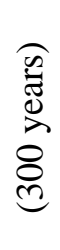 & 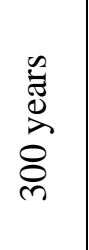 & $\vdots$ & 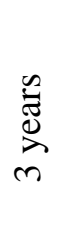 & 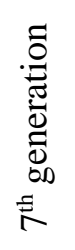 & 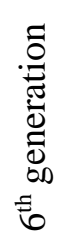 & $\vdots$ & $\vdots$ & 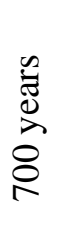 & $\begin{array}{l}\vec{E} \\
.00 \\
\Xi \\
0 \\
\tilde{0}\end{array}$ & 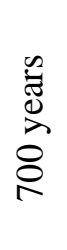 & $\vdots$ & 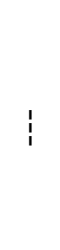 & 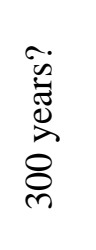 & 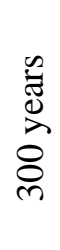 \\
\hline 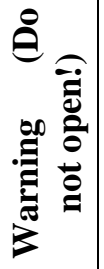 & $>$ & $>$ & $\vdots$ & $>$ & $>$ & $>$ & $>$ & $>$ & $>$ & $\mid$ & $>$ & $>$ & $>$ & $>$ & $>$ \\
\hline $\begin{array}{l}\ddot{\ddot{\theta}} \\
\ddot{\tilde{D}} \\
\ddot{B}\end{array}$ & $\mid$ & $>$ & $\mid$ & $\mid$ & $!$ & $>$ & $!$ & $\mid$ & $>$ & $\mid$ & $\mid$ & $\mid$ & 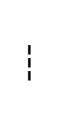 & $>$ & $>$ \\
\hline 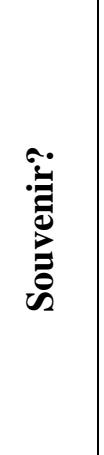 & 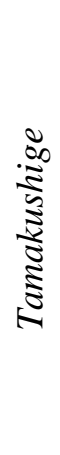 & 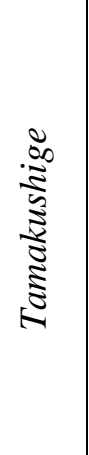 & $\vdots$ & 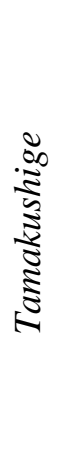 & 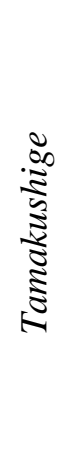 & 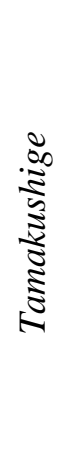 & 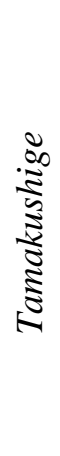 & 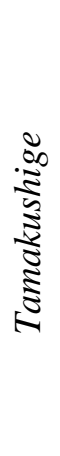 & 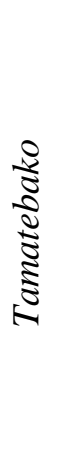 & 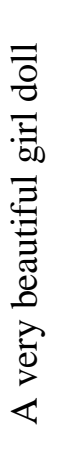 & 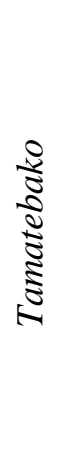 & $\frac{0}{\frac{\pi}{\pi}}$ & 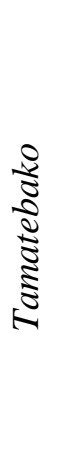 & 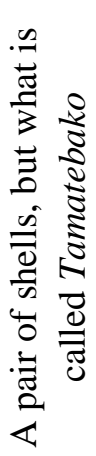 & 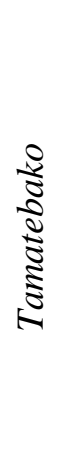 \\
\hline$\dot{z}$ & - & $N$ & $\infty$ & $\nabla$ & 10 & b & $n$ & $\infty$ & $a$ & 으 & $\exists$ & $\mathcal{工}$ & 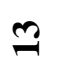 & \pm & $n$ \\
\hline
\end{tabular}




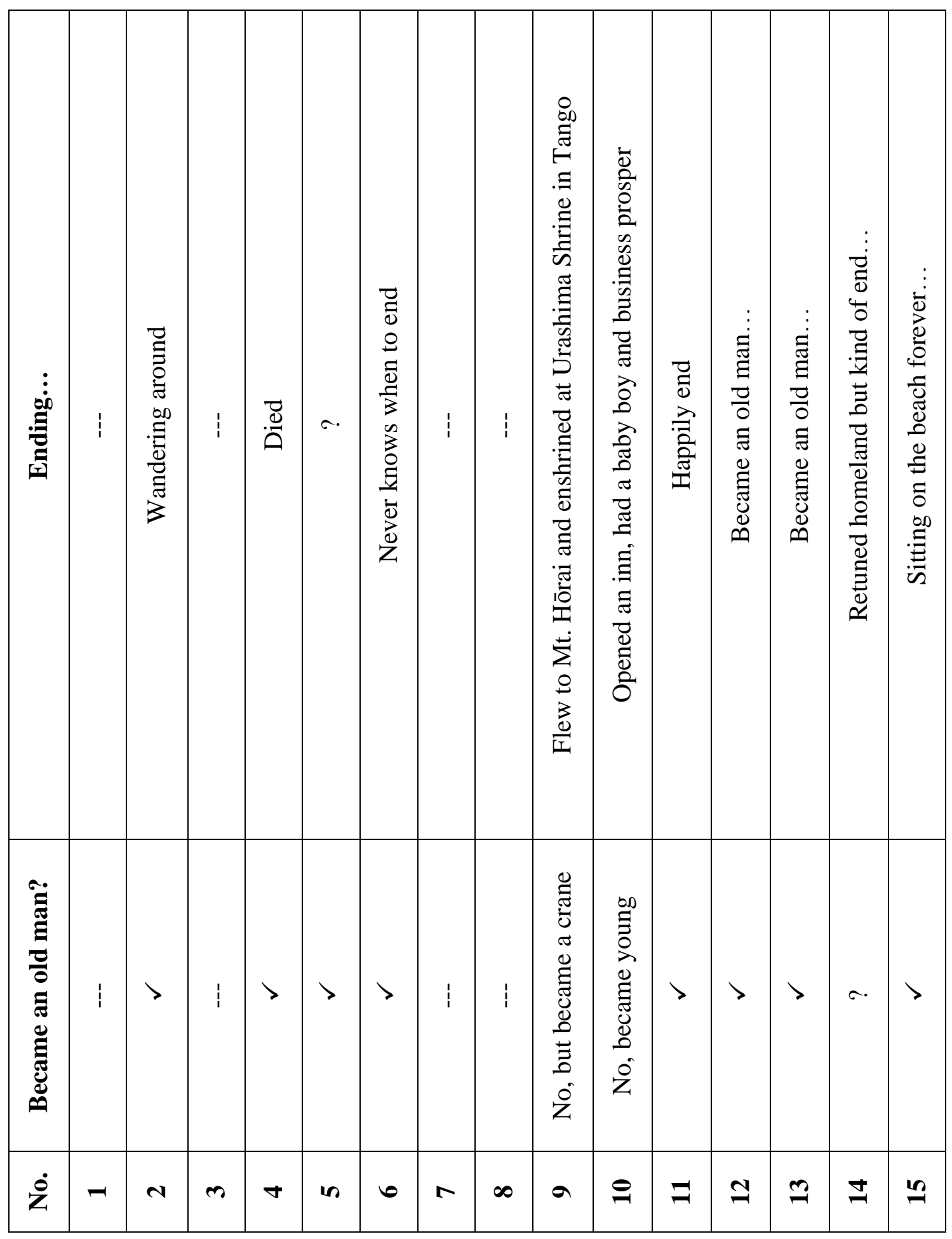




\section{APPENDIX 1 Translations: The Urashima story translated sources}

Note: The numbers below correspond to Table 1 numbers.

\section{Part One}

1. “Urashimako Den" (593-710?), Kojidan (1212-1215)

Source: Shigematsu, Akihisa (ed.). "Urashimako Den” [Kojidan] Dai Isshū

(Shintei Zōho Kokushi Taikei). Tokyo: Gendai Shichō Shinsha, 2006, pp. 2932.

2. Putative completed date of the story: (680-700?), Tango no Kuni Fudoki Itsubun (post 713).

Source: Uegaki, Setsuya (ed.). Fudoki. Tokyo: Shōgakukan, 2006, pp. 473-483.

Cited in: Urabe, Kanekata. "Urashimako", Shaku Nihongi, vol. 12, Maeda-ke bon [MS], late 13th century.

3. Putative completed date of the story: (700?), Nihonshoki (720)

Source: Aston, W. G. (trans.). Nihongi, volume1 - Chronicles of Japan from the earliest times to A.D. 697. New York: Cosimo, Inc., 2008, p.368. (First published in 1896.)

4. Putative completed date of the story: (720-740?), Manyōshū (400-759?)

Source: Keene, Donald (ed.). The Manyōshū, The Nippon Gakujutsu Shinkōkai Translation of one thousand poems. New York: Columbia University, 1969, pp. 216-218.

Source: Cranston, Edwin (Trans. With a commentary and Notes). A Waka Anthology, volume one: The Gem-Glistening Cup. Stanford, California: Stanford University Press, 1993, pp. 323-326.

5. "Urashimako Den” (?-820?), Gunshoruijū (1819)

Source: Shigematsu, Akihisa (ed.). "Urashimako Den”. Tokyo: Gendai Shichō Shinsha, 2006, pp. 40-43. ([Gunshoruijū ] Vol.135. Kokkai Toshokan Zōhon Ichibu Kaitei). 
6. Not translated: “Zoku Urashimako Denki” (920? 932?), Gunshoruijū (1819)

Source: Shigematsu, Akihisa (ed.). "Urashimako Den”. Tokyo: Gendai Shichō Shinsha, 2006, pp. 47-65. ([Gunshoruijū] Vol.135. Kokkai Toshokan Zōhon Ichibu Kaitei).

7. First Urashima story in Fusōryakki (post 1094)

Cited in: $7^{\text {th }}$ Month in Year 22 of The reign of King Yūryaku, Fusōryakki (Shintei zōho kokushi taikei. Tokyo: Yoshikawa Kōbunkan. 1942.

Takioto, Noriyuki. “浦島子伝承の変容 Urashimako denshō no henyō. [The Transformation of a Folktale called Urashimashi]." The Journal of the Historical Association of Komazawa University 56, 2000, pp. 1-37.

8. Second Urashima story in Fusōryakki (post 1094)

Cited in: $7^{\text {th }}$ Month in Year 22 of The reign of King Yūryaku, Fusōryakki (Shintei zōho kokushi taikei. Tokyo: Yoshikawa Kōbunkan. 1942.

Takioto, Noriyuki. “浦島子伝承の変容 Urashimako denshō no henyō. [The Transformation of a Folktale called Urashimashi]." The Journal of the Historical Association of Komazawa University 56, 2000, pp. 1-37.

\section{Part Two}

9. “Urashima Tarō”, Otogizōshi (1716-1736)

Cited in: Ōshima, Tatehiko (annot. and trans.), Otogizōshi. Nihon Koten Bungaku Zenshū, vol. 36, Otogizōshi shū. Tokyo: Shōgakukan, 1974, pp. 414424.

10. Ryūtei Tanehiko. "Mukashibanashi Urashima Jijī” (1830)

In: Suzuki, Jūzō and Kimura, Yaeko (ed.). Kinsei kodomo no ehon shū, edo hen. Tokyo: Iwanami Shoten, 1985, pp. 458-475. 
11. Iwaya, Sazanami (author) and Ueda, Nobumichi (annot.). Nippon Mukashibanashi, No. 18 Urashima Tarō (1896). Tokyo: Heibonsha, 2001, pp. 270-280.

12. Furuta, Tōsaku. “Urashima no hanashi” (1910-1917, Ministry of Education Designated textbook, $2^{\text {nd }}$ edition), Shōgaku Dokuhon Binran, vol. 6. Tokyo: Musashino Shoin, 1983.

In: Miura, Sukeyuki. Urashima Tarō no bungakushi. Tokyo: Goryū Shoin, 1989, pp. 22-23.

13. Furuta, Tōsaku. "Urashima Tarō" (1918-1932, Ministry of Education Designated textbook, $3^{\text {rd }}$ edition), Shōgaku Dokuhon Binran, vol. 6. Tokyo: Musashino Shoin, 1983.

In: Miura, Sukeyuki. Urashima Tarō no bungakushi. Tokyo: Goryū Shoin, 1989, pp. 22-23.

14. Dazai, Osamu. “Urashima san”, Otogizōshi. Tokyo: Shinchō Bunko, 1972, pp. 236-277.

Refer to: Dazai, Osamu. McCarthy, Ralph F (trans.). Otogizōshi: the fairy tale book of Dazai Osamu. Fukuoka: Kurodahan Press, 2011, pp. 23-65.

15. Matsutani, Miyoko illustrated by Iwasaki, Chihiro. Urashima Tarō. Tokyo: Kaiseisha, 1967.

Matsutani, Miyoko illustrated by Iwasaki, Chihiro. Tresselt, Alvin (trans.). The fisherman under the sea. New York: Parents’ Magazine Press, 1969. 


\section{1. “Urashimako Den" (593-710?), Kojidan (1212-1215)}

Source: Shigematsu, Akihisa (ed.). "Urashimako Den” [Kojidan] Dai Issh $\bar{u}$ (Shintei Zōho Kokushi Taikei). Tokyo: Gendai Shichō Shinsha, 2006, pp. 2932.

(In the $2^{\text {nd }}$ year of the Tenchō period in the reign of the Emperor Junwa ( 825 $\mathrm{CE}$ ), Mizunoe no Urashimako, a person of Yosa county, Tango Province, arrived at his homeland by boat in this year.) The hamlet here had sunk under the waves, nothing looked as it used to, the mountains and the rivers look altered, and Urashimako's house was now under water. So Urashimako ran everywhere asking after his family, but there was not a single person there who knew them. When Urashimako asked, "Where are you from? Did you know me before I went away?" There was only one old woman who replied, "I was born in this hamlet and am a hundred and seven years old, but I do not know you at all. However, according to a story my grandfather told, once upon a time, Mizunoe no Urashimako liked fishing and going out to sea, but he never returned home. He did not know that it would take hundreds of years for him to return." When Urashimako heard this, he wanted to return to the maiden but he simply was not able to. It is said that when he yearned for her, and when he opened the treasure box that she had given him, purple smoke puffed out from the box, soared to the sky, and flew away to the west. ${ }^{262}$ (However, it took three hundred years after he had left to return to his home. It is said that he looked like a child.)

It said in the Urashimako den, that in the year 22 of the Emperor Yūryaku' reign (ca. year $478 \mathrm{CE}$ ), Mizunoe no Ura Shimako was on a fishing boat by himself and caught a turtle. While the boat floated on the waves and Urashima was sleeping, the mysterious turtle changed its form and suddenly turned into a beautiful woman. Her face was as beautiful as a pearl, as if $\mathrm{Nani}^{263}$ hid her face with her sleeve and Urashima was entranced. Urashima was so astonished by her beautiful skin as white as that of

\footnotetext{
262 The west, the direction of the setting sun, is believed to be the pure land of Amida Buddha, after death. ${ }^{263} \mathrm{Nani}$ (南威) is a beautiful woman from Jin (晋), a major state in China during the middle part of the Zhou Dynasty and during the Spring and Autumn Period.
} 
Seishi, ${ }^{264}$ that she hid her face and he turned pale. Her eyebrows were like the crescent moon over Mt. Emei, ${ }^{265}$ her dimples were like shooting stars in the Milky Way. Her slender alluring body was like an intact floating cloud that was about to gracefully dispersed, the lightness of her body was like that of a crane poised ready for flight.

Shimako asked "Maiden, what sort of karma do you have to come here and change your form? Where do you live? Who are your parents?" The maiden said "I am a daughter of Hōrai san, the Mountain of Immortality. The place where I live is the golden garden of immortality and the jewelled palace of long life, and my parents and siblings live there in a golden hall. We, you and I, took marriage vows in our previous life and I became a heavenly immortal and was reborn in the palace of immortality, which you became an earthly immortal and enjoyed the waves at Suminoe. I am here now on account of our karma from long ago that we should become husband and a wife, and we should obey our destiny in the mortal world. Please come to the palace of immortality. My long-held wish is about to come true. Please close your eyes." Shimako complied good-humouredly and obeyed the maiden, and suddenly they were at the Mountain of Immortality.

To do that, the maiden and Shimako held hands and reached the palace in the immortal world. And then the maiden made Shimako wait outside the gate. She walked in first and told her parents of their arrival, and later the maiden and Shimako entered the palace together. The maiden's clothes smelled as fragrant as if a spring wind carried the very beautiful perfume of mixed incense. Jingling jade beads sounded like a concert of natural flutes created by the gentle sounds of leaves falling in autumn. Shimako was a fisherman and already a veteran fisherman, too. However, he was a very noble person, above that of the mortal world, and the nobility of his heart was refreshed. A human heart could be strong and weak at the same time, and obtaining immortality made it more sound.

The appearance of that palace was of gold and splendid jewels spread over a red lacquered garden, and the surface of the garden of immortality at the summit of the mountain was full of beautiful jade beads. Lotus flowers were in full bloom in the

\footnotetext{
${ }^{264}$ Seishi (西施) is a beautiful woman from Yue (越), a state in China which existed during the Spring and Autumn Period.

${ }^{265}$ Mt. Emei (Gabisan 蛾眉山) is the name of a mountain in the South-West of Chengdu, Sichuan Province in China.
} 
middle of the pond, and orchids and chrysanthemums that never wither were in bloom around the well. Shimako and the maiden entered the jewelled hall. A fragrant breeze blew a curtain in the room and perfumed it, lifting the hem of the jade blind. The breeze through the green trees curled the floor mat and opened the beautiful curtain, and the suffused moonlight shone like a veil.

They drank the golden elixir of immortality and milk of limestone in the mornings, and drank miraculous infusions and rice wine in the evenings. Sitting on the magic lawn had the power to stop aging, and the iris rhizome worked to extend life. (The maiden said) "When I look at you, Shimako, you get older and are fading, and you are wasting away day by day. I surely know that even though you appear on the outside to enjoy feasting in the immortal palace, in your heart it makes you feel homesick. Please return to your home - you should visit your homeland." Shimako replied, "I have stayed in the caves that were thought to be the entrance to the underworld of immortality a long time and kept on taking mysterious medicines. For some reason, it was not enjoyable, and I was not happy. Basically you became a heavenly immortal and I became an earthy immortal, so we are both ageless. Therefore, we could not turn back time."

To see him off, the maiden gave Urashima a treasure box that was wrapped with five coloured brocade, and tied tightly with various kinds of gold thread and jewellery. She warned Shimako, and said "If you want to see me again, promise me not to open the treasure box." Urashima promised not to and said goodbye. They loosed hold of each other's hands, and Shimako bid her farewell. Shimako got on board his boat, closed his eyes, departed to his homeland, and suddenly arrived in his home Suminoe.

\section{Putative date: (680-700?), Tango no Kuni Fudoki Itsubun (post 713)}

Source: Uegaki, Setsuya (ed.). Fudoki. Tokyo: Shōgakukan, 2006, pp. 473-483.

Cited in: Urabe, Kanekata. "Urashimako", Shaku Nihongi, vol. 12, Maeda-ke bon [MS], late 13th century. 
(It is written in Tango no Kuni Fudoki as follows)

Yosa County, Hioki village.

Tsutsukawa is a hamlet in this village. There was a person called Shimako in Tsutsukawa, an ancestor of the Kusakabe no obito and others. This person was exceptionally good looking and had a sophisticated elegance. He was what we in society call an elegant man, 'Mizunoe no Ura no Shimako'. The following story is consistent with what Mr Iyobe no Umakai no Muraji, a former provincial governor, recorded. Therefore, the details of this old tale are abbreviated here below.

In the time of the reign of Emperor Yūryaku, who ruled from the palace of Asakura in Hatsuse, Shimako rowed out to sea in a small boat and was fishing alone. Three days and three nights passed but he did not catch any fish. He only caught a sparkling five-coloured (blue, red, yellow, white and black) turtle. He thought it strange but put the turtle in the boat. However, this turtle suddenly changed into a woman. This woman was incomparably beautiful.

Shimako asked "There is no one on this ocean and we are very far from the village, so how did you come here?" The maiden replied with a smile, "I thought there is a handsome man on the ocean by himself whom I would like to befriend, and so I come here carried by the wind and cloud". Shimako asked her again, "Where did the wind and cloud come from?" The maiden replied, "From an immortal who lives in the sky. Please do not be suspicious of me but instead promise me your sincere love". Shimako realised that she was the daughter of a god, which allayed his fears and suspicious. The maiden told him "My heart wishes to accompany you forever, in the boundless world and through eternity. But what do you think of this? I would like to hear your answer first". Shimako replied "There is no need to ask me again, how could I hesitate?" The maiden said "Row the boat, and let's go to the mountain of immortality". Shimako did as she said and rowed the boat.

The maiden put Shimako to sleep, and before he knew it they had reached a big island in the ocean. The island looked as if it were covered with gems. The towers both inside and outside of the gate all shone and sparkled. It was such a sight as had never been seen or heard of before. 
They walked slowly hand in hand and arrived at the gate of a magnificent mansion. The maiden said to him "Please wait here for a while," and she opened the gate and went inside. Then, seven children come over and said to each other "Ah, this is Kamehime's husband". Then eight children come and said "This is the partner of Kamehime". With this he learnt that her name was Kamehime (Princess Turtle). Meanwhile, the maiden returned and Shimako told her about the children. The maiden said "Those seven children are the stars of the Pleiades and the eight children are the stars of the Hyades. You do not need to think that is mysterious". The maiden stood in front of Shimako and guided him inside.

The maiden's parents welcomed Shimako and exchanged greetings, and then they took a seat. While the maidens' parents explained the difference between the human and the immortal world, they also talked about the delight of the chance meeting between a human and a god. They then offered Shimako all sorts of delicacies. Her brothers and sisters plied them with drink too. Fair rosy-cheecked maidens from the nearby village also joined the feast. The songs from the immortals' abode resonated far, and the dancing of the female immortals was seductive. This feast was much more spectacular than in the human world. In the world of immortals, the sun never sets. However, the male immortals withdrew gradually in the twilight, until only the maiden remained. The Shimako and the maiden sat shoulder to shoulder, embraced and became husband and wife.

Shimako forgot his former world and spent three years enjoying himself in the world of immortals but suddenly he became homesick and missed his parents. $\mathrm{He}$ constantly sighed and his grief increased day by day. The maiden said, "Something is not right when I see you these days. What is going on? Can you please tell me how you feel?" Shimako answered, “As people said in older times, ordinary people miss their hometown, and even foxes turn to face their home in the mountains to die. I thought this was a made-up story, but now I have come to believe it”. The maiden asked him, "You want to go home, don't you?" Shimako replied, "I left my family and came into this distant immortal world. I was missing them terribly and let my tongue run away with me. But if possible, I wish I could go home and see my parents just for a while”. The maiden wiped away her tears, lamented and said, "Although our love is as solid as metal and stone and we made a promise for eternity, why do you so suddenly jilt me out 
of nostalgia for your home?" They held hands, at a loss, and going over it again and again, they paced back and forth, lamented and wept.

Finally, they let go of each other's hands and separated, and Shimako set off towards his hometown. Everybody, the maiden and her parents, family and relatives, sadly saw him off. At that moment, the maiden took out her favourite beautiful makeup box, handed it to Shimako, and said to him, "If you don't want to give up on me and you want to come back here again, then you should close this makeup box firmly and be sure not to open it". Then they boarded two separate boats. The maiden put Shimako to sleep, and in no time at all Shimako arrived at his hometown in Tsutsukawa. He gazed around, but the people and everything had changed, and they took no notice of him. He could not understand it.

So he asked the people in the hamlet, "Where is the family of Mizunoe no Ura no Shimako now?" A hamlet person said, "Where on earth are you from? Are you asking about somebody from a long time ago? I heard a story from the elders that there was once a person called Mizunoe no Ura no Shimako in a previous generation. He just sailed out to sea alone and never came back again. Three hundred years have passed since then, so why are you asking about him suddenly?" He was dumbfounded and his mind went blank. Nevertheless Shimako desperately looked for his parents in his hometown, and almost one month passed without him finding even one of his parents. Shimako stroked the beautiful makeup box and kept thinking of the maiden goddess. Shimako forgot the previous promise he made, and opened the makeup box on an impulse. All of a sudden, a sweet fragrant odour came out of the box in a puff of cloud, and soared into the sky. At that point, Shimako realised that he had broken his promise and that it would be hard for him to go back and see her any more. He stood there looking back again and again, and paced back and forth, choked with tears.

Shimako wiped away his tears and sang a song:

A cloud stretches to the immortal world, the words of Shimako from Mizunoe Bay stretch there too.

A song in the clear voice of the maiden goddess came flying from afar:

Though the wind blows to Yamato, and I am parted from both you and that cloud, forget me not. 
Shimako missed her unbearably and sang again:

I was enchanted by you, and when I open the door in the morning and am lost in my thoughts, I can hear the sound of the waves on the beach in your immortal world.

Someone from a later generation added the following song:

If only Shimako of Mizunoe Bay had not opened the beautiful makeup box, they would have met again.

A cloud stretched towards the immortal world. Clouds appear constantly one after another. How sad I am that he may no longer see her.

3. Putative date: (700?), Nihonshoki (720)

Source: Aston, W. G. (trans.). Nihongi, volume1 - Chronicles of Japan from the earliest times to A.D. 697. New York: Cosimo, Inc., 2008, p.368. (First published in 1896.)

Autumn, $7^{\text {th }}$ month. A man of Tsutsukaha in the district of Yosa in the province of Tamba, the child of Urashima of Midzunoye, went fishing in a boat. At length he caught a large tortoise, ${ }^{266}$ which straightway became changed into a woman. Hereupon Urashima's child fell in love with her, and made her his wife. They went down together

${ }^{266}$ Or turtle 
into the sea and reached Hōrai San, ${ }^{267}$ where they saw the genii. The story is in another Book. $^{268}$

\section{Putative date: (700?), Manyōshū (400-759?)}

Source: Keene, Donald (ed.). The Manyōshū, The Nippon Gakujutsu Shinkōkai

Translation of one thousand poems. New York: Columbia University, 1969, pp. 216-218.

\section{Urashima of Mizunoé [ix: 1740 - 1]}

When, in spring, the sun is misted,

And going out on Suminoé's shore 269

I see rocking fisher-boats,

They remind me of the things

That happened long ago

Urashima of Mizunoé

Went a-fishing to the sea;

267 “Mountain Hōrai is the P'eng-Lai-Shan of the Chinese, one of the Three Isles of the Genii, which were believed to lie in the Eastern Sea, opposite to the coast of China. This happy group was the paradise of the Genii, who there maintained a sempiternal vigour by quaffing the waters of the fountain of life which flowed for them in a perpetual stream. The pine, the plum, the peach-tree, and the sacred fungus grow for ever upon its rocky shore; and the ancient crane builds its nest upon the giant limbs of its never-dying pine."Catalogue of Japanese paintings in the British Museum, Aderson, p.224. See also Dickins" "Taketori-Monogatari," in the "R.A.S.

Transcriptions," The "Manyōshiu [stet]," and ancient collection of Japanese poems, contains a beautiful version of this legend, which has been rendered into English verse by Mr. B. H.

Chamberlain, in his "Classical Poetry of the Japanese," and of which a prose version may be found in my grammar of the Japanese written language. The Chinese and Japanese legendary lore associated with Horai San is of boundless extent. The Interlinear Kana renders Hōrai San by Tokoyo no Kuni, or Eternal Land, which is quite inadequate.

268 The "Shukai" editor rejects this as an unauthorized addition.

${ }^{269}$ In Yosa District, Tango Province. 
Proud of his plentiful catch

Of sea-bream and bonito,

He did not come back home

Though seven days came and went;

But beyond the bounds of sea

He rowed out his little boat;

Then it happened that he met

The Sea God's daughter.

They talked, agreed, pledged love,

And hand in hand they reached

The Land Everlasting.

There in the Sea God's palace,

In its sweet and inmost chamber,

They might have lived, both he and she,

Never growing old, nor dying,

Until the end of time.

How foolish of this worldly man;

He said to his beloved:

'Let me go home for a while

And take word to my father and mother;

Then, again, as soon as it is morrow,

I shall come back to you.'

'If you will come again 
To this Land of Happiness,

And meet me just as now,

Take this casket, but keep it closed.'

She said to him over and over.

Arriving at the shore of Suminoé

He sought his home, but could find none,

He sought his hamlet, which he could not see.

In wild wonderment he thought:

'In three years since I left,

How could my home be lost,

No trace of fence remaining?

If I open this casket,' he said,

'My old house may appear to me.'

Thereupon he opened it a little.

A white cloud rose out of the casket,

And drifted towards the Land Everlasting.

He ran, shouted, waved his sleeves;

He stamped and writhed upon the ground,

Then swooned upon the beach.

Wrinkles furrowed his youthful skin,

His black hair turned white.

His breath grew fainter and fainter,

As last he died. 
That Urashima of Mizunoé,

I see the site of his adobe.

Envoy

When he might have lived for ever

In the Land Everlasting,

How foolish of that man,

Though of his own choice!

Source: Cranston, Edwin (Trans. With a commentary and Notes). A Waka

Anthology, volume one: The Gem-Glistening Cup. Stanford, California:

Stanford University Press, 1993, pp. 323-326.

$579-580$

[MYS IX: 1744-45/1740-41]

A poem composed on the subject of the youth Urashima of Mizunoe; with tanka

On a day in spring

When the air was soft with haze

I travelled down

To Suminoe shore, and as I watched

The fishing boats

Bob gently on the sea,

There came to mind 
A tale of long ago.

Young Urashima

Of Mizunoe fished for bonito,

Fished for golden bream,

And proud he was of his fine catch.

On the seventh day

He still had not come home;

He rowed beyond

The slope of sea, rowed on

Until he met by chance

The daughter of the mighty deep.

They spoke enticing words

Each to the other, challenge and reply,

And when the thing

That they desired had come about,

Fast bound in troth

They reached the realm of Everworld.

There in the palace

Of the god of the great deep

They made their war

Together, hand in hand,

Into the chamber

Of the inmost mystery. 
They might have lived

Forever in those wondrous halls,

Never growing old

Or dying, through long ages,

But this fool

Of all the foolish world,

He went to his love,

And this is what he said to her:

"Let me go home,

Just for a little while,

To tell Father and Mother

All that's happened to me

I'll come back to you

In a day or two, I swear,"

He said, and she,

His lady love, spoke thus:

"If you would come again

To this realm of Everworld

And meet me

Just as now, heed well:

Take this comb chest,

But never open itbeware!"

Over and over 
She pressed her warnings on him.

But when he reached

The shores of Suminoe

And looked for his house,

There was no house for him to find;

When he sought his village,

There was no village anywhere.

"How strange!" he thought,

And wondered thereupon

"In the three years

Since the day I left my home

How could the house

Have vanished, the fence be gone?

Maybe if I take

This box and open it

There'll be a house here

Just the way there was before."

Then he opened it,

The jeweled comb chest, only a little

And a white cloud

Flew out and drifted off

In a trailing vapor

Toward the realm of Everworld: 
Wildly he ran,

Shouted, waved his sleeves,

Rolled upon the ground;

He stamped his feet in frenzy;

Suddenly

His heart grew faint, he fell.

Wrinkles spread across

The skin that had been smooth and young,

Whiteness fell upon

The locks that had been gleaming black.

Moment by moment

His breath ebbed away, was gone;

At last it was over,

Life died within him:

Young Urashima,

The fisherman of Mizunoe,

Here is seen the site of his abode.

Envoy

You should have stayed there

In the realm of Everworld

Rusty-bladed sword,

Dullard were you on the day 
You willed otherwise, you fool!

\section{5. “Urashimako Den” (?-820?), Gunshoruijū (1819)}

Source: Shigematsu, Akihisa (ed.). "Urashimako Den”. Tokyo:

Gendaishichōshinsha, 2006, pp. 40-43. ([Gunshoruijū ] Vol.135. Kokkai

Toshokan Zōhon Ichibu Kaitei).

In the $22^{\text {nd }}$ year of the Emperor Yūryaku's reign (ca. year $478 \mathrm{CE}$ ), Shimako from Mizunoe Bay in the Province of Tango, was fishing on a boat alone and caught a mysterious turtle. Shimako floated on the waves and slept in the boat off and on. During that time, the mysterious turtle changed its form and turned into a female immortal. Her ornamental jade hairpin reflected on the sea, her face as pretty as a flower. It was as though snow swirled on her sleeves and clouds scudded across her brow. Shimako was entranced because she looked so exceptionally beautiful. Her face was fragrant and her body was firm and well proportioned; she was just like the famed beauties, Yōhi ${ }^{270}$ and Seishi. ${ }^{271}$ Her eyebrows were like the crescent moon over Mt. Emei, ${ }^{272}$ her dimples were like shooting stars in the Milky Way.

Shimako asked the maiden, "What sort of Karma brings you to my small boat? Where do you live?" The maiden replied, "I am a woman of Mt. Hōrai, the Mountain of Immortality and also the head woman in the golden palace. The place where I live is the golden garden of immortality and the jewelled palace of long life. My parents and siblings live there. We, you and I, took marriage vows in our previous life. Then I became a heavenly immortal and was reborn in the palace of immortality, but you became an earthly immortal and enjoyed the waves at Suminoe. I am here now on account of our karma from long ago that we should become husband and a wife, and we

${ }^{270}$ Yang Guifei (楊貴妃) is known as one of the Four Beauties of ancient China. She was the beloved consort of Emperor Xuanzong of Tang (唐の玄宗皇帝).

271 Seishi (西施) is a beautiful woman from Yue (越), a state in China which existed during the Spring and Autumn Period.

${ }^{272}$ Mt. Emei (Gabisan 蛾眉山) is the name of a mountain in the South-West of Chengdu, Sichuan Province in China. 
should follow our destiny in the mortal world. Please come to the palace of immortality. My long-held wish is about to come true. I shall now make you fly to the Mountain of Immortality." Shimako complied good-humouredly and obeyed the maiden, and suddenly they were at the Mountain of Immortality.

To do so, the maiden took Shimako's hand and they reached the palace in the immortal world. And then, the maiden made Shimako wait outside the gate. She walked in first through the Golden Gate, and told her parents of their arrival. Then later the maiden and Shimako entered the palace together. Goddesses lined up, looking like the stars in the autumn sky, the maidens' clothes smelled as fragrant as a spring breeze carrying the fragrance of a hundred flowers. The tinkling of their voices sounded like a concert of thousands of natural flutes created by the gentle rustle of leaves falling in autumn. Shimako was a fisherman and already a veteran fisherman at that. However, he was a very noble-minded person, above that of the mortal world, and the goodness of his heart was refreshed. A human heart could be strong and weak at the same time, and attaining immortality made it more sound.

That palace had gold and crystals spread on the ground within red lacquered fences, and the surface of the garden of immortality at the summit of the mountain was paved with beautiful pearls and coral beads. Lotus flowers were in full bloom in the middle of the still pond, and orchids and chrysanthemums that never wither were in bloom around the well. Shimako and the maiden entered a jewelled chamber. A fragrant breeze blew through their clothes and perfumed a curtain in the room. The breeze through the autumn coloured leaves curled the turquoise floor mat and jangled the beautiful jade curtain. The suffused moonlight shone through a golden window, and the breeze through the pine trees moved the pearl-string curtain like a tune on the harp koto. $^{273}$

They drank the golden elixir of immortality and milk of limestone in the mornings and drank miraculous infusions and sake in the evenings. The thick magic lawn and orchids had the power to stop aging, and the iris rhizome worked to extend life. (The maiden said) "When I look at you, Shimako, you get older and are fading, and you are wasting away day by day. I surely know that even though you appear on

${ }^{273}$ Koto (琴) is a musical instrument, a long Japanese zither with thirteen strings. 
the outside to enjoy feasting in the immortal palace, in your heart you feel homesick. Please return to your village and visit your home." Shimako replied, saying "I have stayed a long time in the caves that are thought to be the entrance to the underworld of immortality, and have kept on taking your mysterious medicines. I am not happy about this. I have stayed at the splendid palace in the underworld of immortality such a long time and have tasted sake from the jade vessel of the immortal with wings as much as I want. It was not enjoyable. Originally, maiden, you showed me a role model of a wife, and I, Shimako, was accustomed to fall in love with you secretly as a husband. Our behaviours and customs became free, and we could not turn back time. Having said that, there are many things that never last, and I could not sleep much. My soul floats in my homeland, and our new chamber floods with my tears. I hope that I will return to my homeland for a while, then I wish to come back here again soon."

The maiden allowed Shimako to do so, and gave him a treasure box that was wrapped with a five-coloured brocade, and tied tightly with various kinds of gold thread and jewellery. She warned Shimako, and said "If you want to see me again, promise me not to open the treasure box." Urashima promised not to and said goodbye. They loosed hold of each other's hands, and Shimako bid her farewell. Shimako got on board his boat, closed his eyes as if he were sleeping, departed for his homeland, and suddenly arrived at his home Suminoe. Then, Shimako met a descendant of the seventh generation and asked after his house, but only the old pine trees grew where it had stood. Shimako was only sixteen years old at this time, and he could not stand the situation. So he opened the treasure box and looked inside. A puff of purple smoke soared to the sky and there was nothing in the box. Shimako suddenly became an old man as white-haired as snow on the summits of the Tian Shan ${ }^{274}$ mountain range or the frost in the Hepu. ${ }^{275}$

\footnotetext{
${ }^{274}$ Tian Shan (天山) is a large system of mountain ranges located in Central Asia.

${ }^{275} \mathrm{Hepu}$ (合浦) is a county of Beihai City, Guangxi, China.
} 


\section{Not translated: “Zoku Urashimako Denki” (920? 932?), Gunshoruijū (1819)}

Source: Shigematsu, Akihisa (ed.). "Urashimako Den”. Tokyo:

Gendaishichōshinsha, 2006, pp. 47-65. ([Gunshoruijū ] Vol.135. Kokkai

Toshokan Zōhon Ichibu Kaitei).

\section{First Urashima story in Fusōryakki (post 1094)}

Cited in: $7^{\text {th }}$ Month in Year 22 of The reign of King Yūryaku, Fusōryakki (Shintei zōho kokushi taikei. Tokyo: Yoshikawa Kōbunkan. 1942.

Takioto, Noriyuki. “浦島子伝承の変容 Urashimako denshō no henyō. [The Transformation of a Folktale called Urashimashi]." The Journal of the Historical Association of Komazawa University 56, 2000, pp. 1-37.

Shimako, a person from Mizunoe Bay, Yosa County in the province of Tango, fished from his boat and caught a large turtle. Then while Shimako was asleep in the sunshine, the turtle turned into a superlatively beautiful woman. He became confused, so he asked the maiden (Goddess) "Why are you here? My emotions are in confusion." The maiden replied "Spring and autumn have come and gone, and it is hard to meet you in the fog. Please do not doubt me. There are things you want that are very close. These are not invaluable. I have a plan. So I am begging you to come with me. Is it possible?" Shimako replied "I am very scared and suspicious, so I want to know what this is all about." The maiden said, "I am a woman from the golden lofty building in the immortal place, Hōrai. My father and brothers are all there. I am from the capital of the immortal place." Her hair was like thin cloud veiling the moon, and it blew in the wind like swirling snow. She had greenish eyeliner, and her eyes shone from her rosy dimpled cheeks. Her figure was very seductive, and he could not but fall in love with her. Urashimako lost his heart to her, as he spoke to the goddess. "The sky will give you longevity, and the land will give you an eternity. This is called the world of immortality, so if you want to obtain the longevity of the immortal world, you should 
row your boat to the mountain of immortality." Urashimako accepted and went to the immortal world to obtain longevity. The maiden said "You can sleep for a while and Shimako suddenly fell asleep.

Later, they reached a big island in the ocean. They disembarked holding hands, and after a long pleasant walk they arrived at a large residence. The maiden pushed open the gate and entered, but Shimako remained standing outside. Seven children passed and said to Shimako, "We are the attendants of the Turtle Princess." He waited a while, and then eight children arrived and said, "We are also the attendants of the Turtle Princess." Later the maiden came out and said, "The Seven small children are the stars of the Pleiades, and the eight small children are the stars of the Hyades. You can soar to the sky." Then she drew Shimako into the garden, and they reached the first guest house. They raised the kingfisher blinds and stayed there. Beautiful songs and music played on the koto floated in, that were completely different from the mundane world. The maiden's parents were there, to embrace Shimako and exchanged endearments. Shimako was offered great hospitality and enjoyed excellent food and wine. Shimako proceeded towards the fragrance of sweet herbs along paving stones that were like clouds. In the mornings he followed her to the pond, where the birds and beasts disported themselves. In the evenings they entered their magnificent apartments, where he touched the maiden's collar. Shimako lost himself in those pleasures. Only, however, he started to think of his father and mother. The maiden saw his distress, and asked him the reason. Shimako replied, "I am like a bird that pines for the branches of

the south, or a horse who longs for the north wind. I am homesick and want to go home for a while. There is nothing to comfort this feeling." The maiden could not contain her emotions, and her tears fell like rain. They took their leave, then she embraced him and they walked around. The maiden gave him a treasure box and warned him, "Do not open this box and look inside." Shimako promised her and returned to his hometown.

\section{Second Urashima story in Fusōryakki}

Cited in: $7^{\text {th }}$ Month in Year 22 of The reign of King Yūryaku, Fusōryakki (Shintei zōho kokushi taikei. Tokyo: Yoshikawa Kōbunkan. 1942. 
Takioto, Noriyuki. “浦島子伝承の変容 Urashimako denshō no henyō. [The Transformation of a Folktale called Urashimashi]." The Journal of the Historical Association of Komazawa University 56, 2000, pp. 1-37.

It relates in the Zoku Urashimako den, that Mizunoe no Ura Shimako was on a fishing boat by himself and caught a turtle. While the boat floated on the waves and Urashima was sleeping, the mysterious turtle changed its form and suddenly turned into a beautiful woman. Her face was as beautiful as a pearl, as if $\mathrm{Nani}^{276}$ hid her face with her sleeve, and Urashima was entranced. Urashima was so astonished by her beautiful white skin like that of Seishi, ${ }^{277}$ that she hid her face and he turned pale. Her eyebrows were like the crescent moon over Mt. Emei, ${ }^{278}$ her dimples were like shooting stars in the Milky Way. Her slender alluring body was like an intact floating cloud that was about to gracefully disperse. The lightness of her body was like that of a crane poised ready for flight.

Shimako asked, "Maiden, what sort of karma do you have to come here and change your form? Where do you live? Who are your parents?" The maiden said "I am a daughter of Mt. Hōrai, the Mountain of Immortality. The place where I live is the golden garden of immortality and the jewelled palace of long life, and my parents and siblings live there in a golden hall. We, you and I, took marriage vows in our previous life and I became a heavenly immortal and was reborn in the palace of immortality, while you became an earthly immortal and enjoyed the waves at Suminoe. I am here now on account of our karma from long ago that we should become husband and wife, and we should obey our destiny in the mortal world. Please come to the palace of immortality. My long-held wish is about to come true. Please close your eyes." Shimako complied good-humouredly and obeyed the maiden, and suddenly they were at the Mountain of Immortality.

\footnotetext{
${ }^{276}$ Nani (南威) is a beautiful woman from Jin (晋), a major state in China during the middle part of the Zhou Dynasty and during the Spring and Autumn Period.

${ }^{277}$ Seishi (西施) is a beautiful woman from Yue (越), a state in China which existed during the Spring and Autumn Period.

278 Mt. Emai (Gabisan 蛾眉山) is the name of a mountain in the South-West of Chengdu, Sichuan Province in China.
} 
To do that, the maiden and Shimako held hands and reached the palace in the immortal world. And then, the maiden made Shimako wait outside the gate. She walked in first and told her parents of their arrival, and later the maiden and Shimako entered the palace together. The maiden's clothes smelled as fragrant as if a spring wind carried the very beautiful perfume of mixed incense. Jingling jade beads sounded like a concert of natural flutes created by the gentle sounds of leaves falling in autumn. Shimako was a fisherman and already a veteran fisherman, too. However, he was a very noble person, above that of the mortal world, and the nobility of his heart was refreshed. A human heart could be strong and weak at the same time and obtaining immortality made it more sound.

The appearance of that palace was of gold and splendid jewels spread over the red lacquered garden, and the surface of the garden of immortality at the summit of the mountain was full of beautiful jade beads. Lotus flowers were in full bloom in the middle of the pond, and orchids and chrysanthemums that never wither were in bloom around the well. Shimako and the maiden entered the jewelled hall. A fragrant breeze blew a curtain in the room and perfumed it, lifting the hem of the jade blind. A beautiful garden lantern lit the silver floor and added beauty to the brocade carpet. The breeze through the green trees curled the floor mat and opened the beautiful curtain, and the suffused moonlight shone like a veil.

They drank the golden elixir of immortality and milk of limestone in the mornings and drank miraculous infusions and sake in the evenings. Sitting on the magic lawn had the power to stop aging, and the iris rhizome worked to extend life. (The maiden said) "When I look at you, Shimako, you get older and are fading, and you are wasting away day by day. I surely know that even though you appear on the outside to enjoy feasting in the immortal palace, in your heart it makes you feel homesick. Please return to your home. You should visit your homeland." Shimako replied, "I have stayed a long time in the caves that were thought to be the entrance to the underworld of immortality and kept on taking mysterious medicines. For some reason, it was not enjoyable, and I was not happy. Basically you became a heavenly immortal and I became an earthy immortal, so we are both ageless. Therefore, we could not turn back time." 
To see him off, the maiden gave Urashima a treasure box that was wrapped with five-coloured brocade and tied tightly with various kinds of gold thread and jewellery. She warned Shimako, and said "If you want to see me again, promise me not to open the treasure box." Urashima promised not to and said goodbye, they loosed hold of each other's hands, and Shimako bade her farewell. Shimako got on board his boat, closed his eyes, departed to his homeland, and suddenly arrived in his home Suminoe.

\section{Part Two}

\section{9. “Urashima Tarō”, Otogizōshi (1716-1736)}

Cited in: Ōshima, Tatehiko (annot. and trans.), Otogizōshi. Nihon Koten Bungaku Zenshū, vol. 36, Otogizōshi shū. Tokyo: Shōgakukan, 1974, pp. 414424.

Once upon a time, there was a person called Urashima in Tango Province. This person had a son called Urashima Tarō, and he was in his mid-twenties. He caught fish for a living day and night, and looked after his parents, but one day he had nothing in particular to do and went fishing. From bay to bay, island to island, and inlet to inlet, there was nowhere he did not go. While he was line-fishing, picking up shells and harvesting sea weed, he fished up a turtle at the place called Eshima Beach. Urashima Tarō said to this turtle, "It is said that among all long-lived creatures, a crane lives a thousand years but a turtle lives ten thousand years. It would be pitiful if I killed you straight away, so I will save your life. You should remember this favour for all time", and he let the turtle return to the sea.

Thus, dusk fell and Urashima Tarō returned home. The next day, when Urashima set off to go fishing again, there was one small boat floating far out to sea. It was strange, but when he looked at it, there was a beautiful woman alone on the boat being carried by the waves, and gradually it approached the place where Tarō was standing. Urashima Tarō said "What sort of person are you to be sailing alone on this dreadful sea?" The woman said, "I asked others to get on the boat, but there was a 
storm and a lot of people were thrown into the sea. However, there was a very kind person who helped me get on the boat and set it adrift. I was sad, and having no idea where I was going, I feared to go to Demon's Island. But now, I came across you. This was my destiny in this world. Therefore, even a tiger and a wolf and a human have destiny." She was weeping silently. Urashima Tarō being neither tree nor rock, he pitied her, and took hold of the boats' hawser and pulled it toward him. Meanwhile, the woman implored him saying "Poor me, could you please send me back to my home country? If I were abandoned by you, I would not have any idea what I should do or where I should go. If you abandoned me, it would be the same feeling as while I was on the sea." The woman was weeping silently, so Urashima Tarō took pity on her, jumped on her boat, and started to row it out to sea. Following the woman's instructions, they spent more than ten days on the sea before reaching her home.

Well, now, as they got off the boat Urashima marvelled at what kind of place this was - it had silver walls and golden tiles on the roof surrounded by house, and an impressive gate. Even a house in heaven could not match this. The place in which this woman lived was beyond description, or at least it could not be put into words. Now the woman said "To live in the shade under the tree or to scoop water from the same river, is all our karma from a previous life. Bringing me here far way across the sea must surely be due to karma from a previous life, so although some things will be difficult, we should exchange marriage vows and live here together forever." She spoke courteously. Urashima Tarō said, "I shall do as what you say, at any rate." They then promised to live faithfully together till death, ${ }^{279}$ which was not to be taken lightly. If they were in the sky, they would have been hiyoku birds, ${ }^{280}$ if they had been on land, they would have been renri branches, ${ }^{281}$ so they exchanged marriage vows, ${ }^{282}$ which were not taken wantonly, and they spent their days and nights together.

${ }^{279}$ Kairō dōketsu (偕老同穴): It means a married couple live and get older together, even when they die, they will be buried in the same grave.

${ }^{280}$ Hiyoku no tori (比翼の鳥): Chinese imaginary bird, the male and female each having only one eye and wing, so that they always fly together. This is a metaphorical expression for a really good relationship between husband and wife.

${ }^{281}$ Renri no eda (連理の枝): From Classical Chinese poetry. A tree branch from two different trees grafted together on the ground. This is a metaphorical expression for a really good relationship between husband and wife.

${ }^{282}$ En'ō no chigiri (鴐鴫の契り): This means a lovebird's promise, a metaphorical expression for a really good relationship between husband and wife. 
By the way, the woman said "This is the place called ryūgüjo (The Sea Palace), and the trees and flowers as expressions of the four seasons appear in the four directions here. Please come in and look." So she took him out to that place. To short with, if you opened the East door and looked out, you would imagine that it is spring scenery: plum trees and cherry blossom trees are blooming in profusion, threads like willows are bending in the spring breeze in the haze. The song of the $u g u i s u^{283}$ is also heard close to the house, and each treetop is covered in flowers. If you looked to the South, you would imagine that is the scenery of summer: there are unopened buds of unohana ${ }^{284}$ in the hedge that separates it from the spring; the lotus plants in the pond have dewdrops on them, and many waterfowl are playing on the pleasant cool small ripples on its shore. The foliage of the treetops have grown thick, the sound of the cicadas hangs in the air, and the song of the hototogisu (a little cuckoo) through the clouds after a rain shower tells us it is summer. The West looks like autumn: all the leaves on the treetops have turned red and gold, there are white chrysanthemums inside the bamboo-made lower hedge, bush clovers push through dewdrops at the edge of a misty field, and the belling of a deer tells us it is autumn. And now, if you gaze to the North, you would think it a winter scene. All the treetops and leaves are withered because of winter. There is the first frost over the fallen leaves, the mountains look just like a white cloth. The charcoal-burning of poor man, whose house in the valley is buried in snow, is conspicuous because of the rising smoke. This is a scene which tells us it is winter.

Well, interestingly, they enjoyed themselves, proud of their prosperity, and lived together, and three years passed in this way. Urashima Tarō says, "Can you give me thirty days of my own time? I abandoned my parents in my hometown, and went on a temporary trip, but I spent three years here, so I am worried about my parents and feel anxious. If I see them, I will be relieved." The woman said, "For three years since we exchanged our vows, I have dedicated myself, and worried and cared about you when I did not see you even for just a moment. However, if we separate now, when can we meet again in this world? It is said that a married couple's destiny is joined in the present life and in the afterlife. Therefore if our vows were a dream or illusion in this world, we will be born in our next life into the land of happiness without a doubt." And

\footnotetext{
${ }^{283}$ Uguisu (鶯) is the Japanese Bush Warbler, Cettia diphone, is a passerine (suzume-moku スズメ目) bird more often heard than seen. Its distinctive breeding call can be heard throughout much of Japan from the start of spring.

${ }^{284} U$ no hana (卯の花): Deutzia is a genus of about 60 species of shrubs in the family Hydrangeaceae.
} 
she wept silently. Then the woman said, "I do not need to hide it from you any more now. I, myself, am a turtle of the Sea Palace and was rescued by you at Eshima Beach. That is why in return for your favour I exchanged vows with you and became your wife. This is a token from me. Please think of it that way." So saying, she took out a beautiful box that had been tucked under her left arm, and said, "Do not open this box no matter what happens", and gave it to him. Knowing that all who live must die, and all who meet must part, and knowing too that it would be very hard to stop him, she sang,

Counting the days and piling up the formal costumes for travel, we can separate now, but I wonder when can you come back and see me.

Urashima replied in verse,

I am in a daze about parting from you but our promises were deep and strong, and I will come back here to see you.

While Urashima Tarō was sad and they did not want to leave each other, he picked up the token box and went back to his hometown. He was thinking about unforgettable days with her so far and their future, and returned far across the sea. Urashima Tarō sang,

An image of the person with whom I exchanged my promises temporarily, I never forget about her, and what I should do.

Anyway, Urashima went back to his hometown and looked around there. There were not many people there and the land was ill cared for. When Urashima saw it he thought about what had happened. When he looked in the distance, there was a shack in the bush, so he stood over there and called, "Anyone a home?" An old man who looked in his eighties came out from inside, and said "Who are you?" Urashima asked "Is there anyone named Urashima around here?" And the old man said, "I was wondering what kind of person you were, but you asked me about the Urashimas. That is very strange. A story has been passed down that a family called Urashima lived here seven hundred years ago." Tarō was so surprised, and wondered what was going on here, so he told the man everything about himself. And the old man thought it was strange too, and said with tears, "That old mound over there, is a tomb that is his grave." He pointed it out to 
show him. Tarō, crying a lot, pushed through the deep grass of the field, and arrived at the old mound, singing while he cried,

I left temporarily and came back here, but it became all over-grown fields, which is so sad.

So Urashima Tarō rested in the shade of the pine tree and was devastated. Tarō thought about the token box that he had been told not to open no matter what happened, but what could he do now? And he did not care any more. So he thought he should open it. He regretted looking inside. When he opened the box, three purple clouds puffed out from inside and floated away. When he saw it, his age of twenty-four or five years old suddenly changed. Urashima turned into a crane, soared, and flew away into the sky. Originally, the turtle put Urashima's age into the box. That's why seven hundred years of age was able to be frozen. He was told not to open, it and it would not be good to open it. It was even written in a song.

When the night I meet you is like Urashima's box, I regret it. When the dawn breaks, just like opening the token box, I regret it, and my tears flow.

There is no one who has a life who has not got sympathy. Needless to say, as a human, if you ask a favour to someone but you know the favour from them, it is like a stone and a tree. It is saying that a deep strong merciful couple will be a couple again when they are born into their next life, and this is truly thankful. Urashima became a crane and they went to Mt. Hōrai ${ }^{285}$ together. The turtle prepared sanseki no iwai ${ }^{286}$ on her shell and lived eternally. Therefore, the crane and the turtle are often featured in happy occasions. Mind you, people should have mercy, and it has been said that a person who has mercy will have a good future. Later on, Urashima Tarō became the well-known god Urashima $M y \overline{o j} i n^{287}$ in Tango Province, and saved people from agony and going astray, and led them in the right direction. The turtle was enshrined in the same place and became a married god. These are such wonderful examples.

\footnotetext{
${ }^{285}$ Mt. Hōrai is the mountain of immortality.

${ }^{286}$ sanseki no iwai (三せきのいわみ): unknown meaning, it could be three celebratory products?

${ }^{287}$ Myōjin (明神) is a god.
} 


\section{Ryūtei Tanehiko. “Mukashibanashi Urashima Jijī” (1830)}

In: Suzuki, Jūzō and Kimura, Yaeko (ed.). Kinsei kodomo no ehon shū, edo hen. Tokyo: Iwanami Shoten, 1985, pp. 458-475.

\section{Folktale: Grandpa Urashima (Part 1)}

I asked a person from the Echigo ${ }^{288}$ region about stories for small children, and there are three or four folktales that have now died out in Edo. This is one of them, and I wonder if it should be called a variant of Urashima Tarō. The origins of the Shianzake ${ }^{289}$ at Kireto ${ }^{290}$ beach is the only true part of the story. The rest, up to the section where a wooden doll goes back to the Sea Palace, I merely write down as I heard it.

There is a simple pub at Ama no Hashidate in Kireto. Shianzake is named after Monju no Chie. ${ }^{291}$

"While I am drinking Shianzake| clouds from Kireto disappear| and it will be sunny from an evening shower| at Ama no Hashidate."

\section{Urashima Tarōsaku}

The princess from the Sea Palace

"My hair is as though| the snow from last year| has all disappeared,| and it has regained its colour| like willow trees in spring."

Around Miyazu in the Tango region was a very lively place from olden times because the Emperor had sent an official to govern that region. So there were a lot of houses without much space between them, but there was one small house that was remote from these busy areas. The head of the family's name was Tarōsaku, and he was

\footnotetext{
${ }^{288}$ Echigo (越後) is an old name for the region of present day Niigata prefecture apart from Sado Island.

289 Shianzake (思案酒) was served at a teahouse in front of Chionji in Kyoto.

${ }^{290}$ Kireto (切戸) is a beach at Miyazu, Kyoto.

${ }^{291}$ Monju no chie (文殊の知恵) is associated with transcendent wisdom in Mahāyāna Buddhism.
} 
an old man of almost seventy years of age. His wife Minawa was around sixty years old and did not have any children or assets that she could pass on to anyone.

However, she did not complain much about it, and the couple only made straw snow boots companionably together. They had been making a living here like this for about twenty years by selling these products at the market. Originally, Tarōsaku used to be a fisherman around Ama no Hashidate, where he fished day and night around all the islands and bays, so people called him Tarōsaku of the islands and bays [Urashima]. Even after they moved here to settle down, people gave him the nickname Grandpa Urashima.

Now, one day, while flattening the straw to make the straw snow boots, his wife Minawa said, "You are good at fishing so we were not poor when we lived at Ama no Hashidate. But even if it is in order to make a living, you should not kill creatures when you get older, so you snapped your fishing rod in half, ripped up the fishing net, and we moved to Miyazu. We became a very poor couple and our life is hard. There is not much snow these days, and the streets are not muddy, so there are few people buying our boots. It is the $19^{\text {th }}$ of December today, and the end of the year is approaching, so you should cut down the pine trees and peddle them in Miyazu town. It would be more profitable than selling the straw snow boots." "Indeed," thought Tarōsaku, and being so honest, it upset him that his wife had said the end of the year was getting close...so he went to the mountains the next day to cut down the pine trees.

He shouldered them on his back for as far as he could walk, calling loudly "pine trees for New Year's decorations!" But no one bought them because it was a week or so too early. Tarōsaku was completely exhausted, and took a break on a certain beach. He started to think to himself, "There are no mountains that have pine trees in the Sea Palace. I caught a lot of fish in the past that were of the Sea King's household, so as my repayment for making a living by them, please let me dedicate these pine trees to decorate the East Gate with them." So saying, he flung the pine trees he had been shouldering into the sea and went home. 
Folktale: Grandpa Urashima (Part 2)

Tarōsaku went to bed that night so tired that he did not know what he was doing. Around mid-night, someone knocked at the gate. Tarōsaku heard some noise in his sleep, so he opened the door and gazed out of the gate. Then he asked, "I do not know you, so what do you want?" That person bowed in reply, "I am Kamezō, a servant of the Sea King's daughter, and have come to invite you, old man. We shall not offer you wine, but let me invite you. Come!" Tarōsaku did not know why, but he was never suspicious of what anyone said. So he said "In that case, let's go." He set off with that person. When they reached the beach where Tarōsaku had hurled the pine trees into the sea that evening, Kamezō pointed to his back and said "Close your eyes for a while and allow me to carry you on my back." Kamezō held Tarōsaku tightly on his back, and dived into the sea.

By the time he thought that they had gone for about one kilometre, Tarōsaku opened his sleepy eyes and looked into the distance, and there was a beautiful gate decorated with pine tree greenery. In due course, one child came and said "Please come" and invited Tarōsaku into the far hall. The blinds were of crystal, the red railings were of cinnabar, the gravel spread in the garden was of jade, and its beautiful style was beyond description. While Tarōsaku was wandering and gazing around, a fascinatingly elegant princess of about sixteen or seventeen years old, who looked like Seiōbo, ${ }^{292}$ came out quietly attended by many women. She, Otohime, said "I am a daughter of the Lord of this Sea Palace. Since you so commendably dedicated a number of pine trees to us, we were able to put up pine tree decorations at the gate, which is very unusual for the Sea Palace. My father is so delighted that he asked me to invite on his behalf." I shall offer you sake and then I shall show you the treasures that the Palace has inherited. “Come, now!" she said. Ladies brought sake bottles and dishes, and eventually offered him sake. Tarōsaku was not fond of sake, but this tasted like nectar, his heart was refreshed, and he became a bit tipsy. Before he realised it, he had downed a couple of capfuls. Then he was invited to see the palace treasures, so he went out into a place like a long corridor. It was about a hundred and eighty metres long, and the whole length of it was finely decorated, including corals piled up like the logs of the human world, precious medicine made from the horns of unicorns, febrifuges made from rhinoceros

${ }^{292}$ Seiōbo (西王母) is a female immortal. 
horn, and there was also something that reflected as if gold. He was dazzled by these decorations. Then the aforementioned Kamezō came back and tugged at Tarōsaku's sleeve. He asked, "I was ordered to ask you to choose one of the ornaments that you like, whatever you want, so which one would you prefer?" Tarōsaku was unselfish by nature so he had no need to consider it. He simply replied, "May I have the very beautiful girl doll in the third decoration? I don't have any children, so I shall look upon her as my daughter, and it will keep me company when I am lonely. There is nothing else I would rather have." However, his words could be heard from inside the blinds, and then the princess emerged. She had the doll taken down and given it to him. She said "You didn't set your sights on gold, silver or jewels, so your pure heart will reach the sky, and you should become a wealthy man. This is only an inanimate object, but it is one of the best treasures in the Sea Palace. You should put it in your room when you go home, and offer it steamed rice in a small purified bowl for one night, then look at that bowl the next morning without being seen by anyone. Without doubt, you will have luck." When she had finished telling him this, she looked back at him, and said "The old man's wife is desperately missing him, so we should send him home now." So Kamezō held Tarōsaku on his back as before, and they departed.

Creatures do not know the alphabet and cannot understand their meaning. I just wrote down the child's story as I was told it.

Minawa was terribly worried that her husband Tarōsaku just gone out somewhere in the night and had not come back next evening. So she went round all the neighbours asking after him, even into the night. Just when she was thinking of him, Tarōsaku turned up looking happier than usual, holding a beautiful doll, and walked into the house. So Minawa clung to him and said "Did you lose your mind? You had better calm down." Tarōsaku laughed and said, "It is as if I am looking at a small child. You might think I am insane because I have brought back a toy, but it is not like that at all." And he told her everything that had happened to him from beginning to end.

Folktale: Grandpa Urashima (Finale)

Minawa's mind was not twisted but she was greedy by nature, so she got more and more infuriated as she listened to Tarōsaku's story. She said, "You didn't take the 
corals, precious medicines, or gold and silver things, but you brought this useless girl doll? Your mind is to bring back a doll! Have you not changed since youth, that you bring back a beautiful woman, though it is only a doll?" Then, she begrudged him, and turned her back on him, and stopped speaking to him. Tarōsaku took no notice, but cooked some steamed rice in a clay pot. However, he had no purified bowls, so he took out a new small wooden measuring container that had not been soiled, and heaped steamed rice into it. He placed the doll in the room, and offered the rice in front of the doll. Then he got up earlier than Minawa the next morning and looked at the measuring box. The offered rice had all disappeared, and the measuring box was full to the brim with large gold coins instead. He took them and hid them without telling Minawa. He did the same thing as the previous night, offering steamed rice in the measure, which then changed into large gold coins by the following morning. The same thing happened night after night, and Tarōsaku suddenly acquired a large amount of money. However, he did not repair his broken house or replace his old clothes. $\mathrm{He}$ not only gave the gold to beggars and outcastes, but also to poor people without anyone knowing.

The house they lived in was very tiny and Tarōsaku tried to hide his secret. But his wife Minawa somehow learnt about it, and started to suspect that something strange was happening, and that if it one pint of rice was offered, it turned into one pint of large gold coins. Therefore, she reasoned, if ten times as much were offered, it would turn into ten times as many gold coins. She thought she would give one-tenth of them to her husband and keep the other ninety per cent for herself. So she secretly took down that one-pint rice offering that Tarōsaku always offered, heaped up ten times as much steamed rice so high in a bigger measuring box, and then tidied up and went to bed as though nothing had happened. When she woke up close to dawn and peeped at Tarōsaku, he was still fast asleep and snoring loudly. She thought this was a good time, so she opened the thick papered sliding door slowly, took out a lamp, and looked at the offering. But the room was messed up with urine everywhere and turds were heaped up in the container! Minawa thought "What a mess! So she covered her nose with her sleeve and got out of the room. She thought how hateful the doll was. A very small amount offered by her husband had changed into gold coins, but her offering had turned into such filth! She tried to smash the doll, but all of a sudden it stood up and started to talk to her like a human. "It was the order from the princess to the old man 
that the offering should be in such a small bowl. I ate so much more than normal that I got a sore stomach and soiled the room. I will clean up, and purify it for you." As soon as the doll finished speaking, it instantaneously turned into a dragon. It smashed the roof and pushed over the pillars. It started to pour with rain, clouds formed, and it flew away. Minawa was so scared that she begged forgiveness, but she fainted and what is more, she lost her mind.

Tarōsaku yawned calmly, stretched out and got up. When he saw the suspicious body of Minawa, he did not understand, but he approached closed to her and propped her up with his arms around her. However, she was unconscious. He was astonished and wondered what had happened. He repeatedly called her name, Minawa, as hard as he could shout. Finally, she regained consciousness because of his shouting. She looked around while telling him the story, but there was no damage to their home, or rain. She wondered what was going on and was scared stiff, but she could not tell whether it had been reality or a dream. Tarōsaku also thought it odd, and when he looked up at the shelf where the doll had been put, the doll had disappeared.

He thought it was more and more curious, and he wondered what was in the box, so he took off the lid. It was full of gold coins which sparkled for one moment, and lit up Tarōsaku and Minawa's faces. Then Tarōsaku's face changed to about twenty years of age and Minawa's face turned into its former beauty of around seventeen or eighteen years of age. They were amazed and stood up, and their old bent backs could stretch straight again. Even their minds were rejuvenated, so the unexpectedly young couple looked into each other's eyes and were dumbfounded.

Seeing this mysterious incident right before their eyes, Minawa reformed her avaricious heart, and Tarōsaku was delighted. They moved to the vicinity of Kireto at Ama no Hashidate, and opened an inn with the capital from the box. Gradually his business prospered. And the sake which he called Shianzake created much wealth for them.

The Chinese character saku of his name, Tarōsaku, was not suited to a young man, so he changed his name to Tarō. In no time at all Minawa became pregnant. She gave birth to a lovely baby boy, and they lived thereafter without any difficulties at all. A very fine and happy ending! 


\section{Iwaya, Sazanami (author) and Ueda, Nobumichi (annot.). Nippon \\ Mukashibanashi, No. 18 Urashima Tarō (1896). Tokyo: Heibonsha, 2001, pp. 270-280.}

Japanese folktale

No. 18 Urashima Tarō

Once upon a time, there was a fisherman called Urashima Taro in Mizunoe, Tango Province. One evening, when Urashima Taro was on his way home from a beach after fishing as usual, children, aged around eight and ten whose leader was twelve years old, got together and caught a turtle. They were pulling this turtle to the right and left, back and forth, playing with it terribly like a toy, throwing stones and hitting it with a stick, and beating up the turtle.

Urashima was a compassionate man, so he thought it was sad when he saw it, and said "Look, you are bullying the turtle so badly, this turtle will be dead soon." However, the naughty children would not readily listen to him and said "We don't care even if the turtle dies. It is fun, so we'll keep on doing it." They were beating up the turtle more terribly, so Urashima considered and said "Look, you guys are good children really, so can you give me this turtle, just for me, an old man?" The children said "No, no way! We caught it." But Urashima gently said "Yes, it makes sense, but I am not saying that you should give it to me for nothing. I will give you some money instead, which means I, the old man, will buy this baby turtle. All, right? Then you can buy whatever you want with this money and it will be much better. See, you are such good children, so let's do that." The children were so pure and innocent that they changed their minds, and said "OK, we will give you this turtle, so can you give us some money?" They exchanged the turtle for money, and said "Come on everyone!", and they went off somewhere else.

Later, Urashima said while he was stroking the turtle shell, "Oh dear, you poor thing. We say a crane lives one thousand years, and a turtle lives ten thousand years, so you have the longest life in the world. Although you were caught by the naughty children and were about to be killed, I just walked by and helped you, which means you still have a life and longevity. Well, I can let you go now, and you should go home 
soon before someone else catches you." Urashima carried the turtle all the way to the beach, released it into the water, and he went back home.

Then, the next day, Urashima rowed out on the boat again in the morning, went far out to sea, and there was someone who was calling "Mr Urashima!" while he was busy fishing.

"What? There was no boat around here and there shouldn't be anyone here, so I wondered who just called me." Urashima looked around there carefully, astonished, and one turtle had come here before Urashima noticed it.

Urashima was surprised again, but asked "Hey, Turtle, it is you who just called me?" The turtle replied, bowing his head, "Yes, it was me. Thanks to your help yesterday, I had a narrow escape, thank you very much. That's why I am just here to say hello." Urashima said "I see. It is kind of you. Well, I would like to say please come here and have a cigarette, but you are a turtle, so I guess you don't smoke, do you? Ha ha ha!" The turtle replied, "Ha ha ha. I would prefer sake, it is my favourite, but I don't think I can have a cigarette." Urashima said "I understand. There is no sake here unfortunately, but you should come up here and you can dry your shell or something." While he was humouring him, thus the turtle eventually asked him "Have

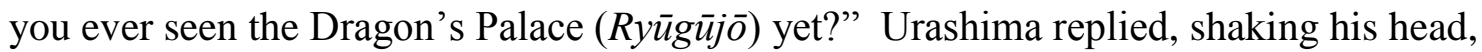
"Not yet. I go to the sea all the time, but I have never seen it yet. It looks quite a distant place." The turtle replied, "I see. You said it is far, but you can go there fast if I go with you. Shall I guide you if you would like to see it? "What? Will you guide me? It is very kind of you, but you are so used to going there. However, I cannot swim as much as you can..." Even before Urashima had finished speaking, the turtle said, "Well, you don't need to swim by yourself. It is easy to go there if you can just hang on my back." Urashima said "How can I hang on such a small back?" The turtle replied, "It is funny, but actually you can do that, by the way. You will never know unless you try, so come here and jump on me." When he looked at you the turtle shell at that time, it mysteriously became much bigger than before as if one person could sit there easily.

Urashima repeatedly said, "No wonder, it was mysterious." And still saying "Well, please take care of me, Mr Turtle. Ahhh..." He hunkered down on the turtle shell, but the turtle replied with a straight face, "It is time to go." And the turtle started to swim over the waves to the Dragon's Palace. 
After a short time, they could see a splendid gate ahead.

Urashima asked "I can see a big object that looks like a gate. What is that, Mr Turtle?" The turtle replied "That is the Great Gate of the Dragon's Palace, so the big roof beyond that point should be the Palace." Urashima replied too, "I see, so that means we have arrived at the Dragon's Palace, haven't we?" The turtle answered, "Yes, indeed. How fast we got there." While they were talking like this, the turtle came close to the gate and said "Here we are. Please walk from now on." Then the turtle stood first, and said to a goby fish guard "Dear guard, I bring Mr Urashima Tarō from a country called Japan, so please answer the door." Then the goby guard swam to the far end immediately, and repeated the arrival of the guest.

Soon, the leaders of attendants such as a sea bream, a flounder and a sole politely welcomed them, and said "Welcome to the Palace, and thank you very much for coming all this way, Mr Urashima, and the same to Mr Turtle. Please come this way." And they led Urashima and the turtle inside.

Urashima did not understand the situation but he did not feel bad anyway, so he just walked to the Palace with a perfectly straight face. When he got there, the lord of the palace, and a princess who had changed into her kimono clothes, with a lot of her followers, was there to welcome them.

When Urashima saw thus, he made to bow, but before he could do so, the princess took his hand quickly, and made him sit on the guest seat, and said "Welcome to the Palace, Mr Urashima. Thank you very much for saving the turtle yesterday. It might be very rude in return for it, but we would like to offer you to enjoy a feast, which is why we have invited you today. Anyway, please relax and enjoy yourself." Therefore, Urashima thought it was a waste of time to behave with modesty, and replied "It was very kind of you, and thank you so much. It was the first time for me to visit the Dragon's Palace. Everything I see looks out of the ordinary, and there is nothing interesting compared to this." The princess said "It is my pleasure and good to know that."

It had probably been arranged previously, but while they were talking the nibbles, feast and sake were brought, songs and dancing were started, and it became a very lively drinking party. 
It was the first time in his life for Urashima to enjoy such a feast, so he was delighted and completely absorbed in this party. Before long, the drinking party finished, and they went walking for exercise and did sightseeing everywhere in the Dragon's Palace.

Urashima was taken with the princess and saw everywhere in the palace, but so many ornaments were decorated such as coral reefs and pearls, that it was beyond description. However, the very mysterious thing was the garden scenery. Spring, summer, autumn or winter, it just appeared in one moment. When you look to the East first, plum trees and cherry blossom trees are in full bloom, bush warblers, Uguisu ${ }^{293}$ are singing, and butterflies are flying and so on. When you look to the South, trees and leaves are green and luxuriant, and the cicadas and higurashi ${ }^{294}$ are crying. When you look to the West, maples and chrysanthemums are blooming in their peak. When you look to the North, pure white snow has accumulated and the pond is iced up.

Urashima had never in his life been to such a wonderful place, so he was simply delighted, forgot his home, and spent a couple of days without thinking of it, but he finally realised and said, "Oh dear. I cannot be like this all the time. I have my parents at home. I have not been there since I left, so they must be worried about me. I should leave now." He packed in a great hurry and said, "Thank you so much for entertaining me for such a long time, but it is time for me to leave." However, the princess eagerly detained him and said, "Well, you don't need to go, and you may stay here. You should stay one more night." But Urashima replied, "I have to go no matter what happens." He looked as though he would not heed her easily, so the princess gave him a magnificent box and said, "It cannot be helped. I can let you go today. I will give you this item as a token instead, so please take this with you." Urashima felt guilty about this offer, and asked, "I had a feast, and I felt guilty for this offer if I also received such token, but it was your courtesy so I will take it. But what is this box?" The princess handed him the box, and warned him repeatedly, saying, "This is a treasure ox that contains something precious. However, you are not to open it no matter what happens. If you open it, you are going to be in big trouble."

\footnotetext{
${ }^{293}$ Uguisu (鶯) is a bird, bush warbler, representative of early spring for its song.

${ }^{294}$ Higurashi (蜩) is an evening cicada, Tanna japonensis, a seasonal word for late autumn.
} 
Now Urashima received the treasure box and took his leave of the princess, jumped on the turtle's back again, and returned to the original beach.

However, where was this place? This was the same beach as previously without a doubt, but there were too many unfamiliar faces that were walking around there. He briskly walked and went back to his own home while he was thinking it was strange. When he tried to enter the house, while he was saying "I am home, Dad." there was a stranger inside. Urashima thought they must have moved while he was away, so he was a bit cautious and asked, "Excuse me. I am Urashima Tarō. I lived here just a while ago, but where did they move to during my absence?" The man in the house looked strange, gazed at his face, and said, "Are you Urashima Tarō?" Urashima replied "Yes, indeed. I am Urashima Tarō." The man replied "Ha ha ha, you are kidding me, I see. A person called Urashima Tarō lived in this area, it is true, but that was already seven hundred years ago, and he is not likely to be alive now." So Urashima was astonished, and said, "Excuse me, but you are joking. I am indeed Urashima Tarō and I lived here until three or four days ago. Seven hundred years is just silly." However, the man became more serious and said, "I am not sure whether you are Urashima Tarō or not, but Urashima was a person seven hundred years ago, so you are probably a ghost." Urashima replied, stamping his feet on the ground. "Do not say such a silly thing. I am alive as you can see. I have feet, haven't I? See!" But the man said, "Urashima Tarō certainly lived seven hundred years ago, that's too bad." He did not believe him at all, so Urashima was nonplussed, and looked around all over the place. Then, he realised that everything was completely changed from when he was there, so he should think that what the man said was true. Urashima was greatly confused as if he was dreaming, so he went to back to the beach quickly and became aware of the treasure box that he had been holding. He talked to himself, "The princess said I should never open this treasure box because there is something very important in it when she gave it to me just before. However, I have lost my house, I know no one, I am lonely, and I cannot do anything about it, so it might be helpful if I open it at such a difficult time. How about it?" Urashima should not have opened it but he undid the string and removed the lid of the treasure box. What a miracle! Three lines of purple smoke puffed out from inside the box, and Urashima thought the smoke would cover his face. Then, twenty-four or - 
five year old Urashima gradually became an old man with lots of wrinkles, and he was not even able to stand up by himself. Happily, happily, ever after [stet]. ${ }^{295}$

\section{Furuta, Tōsaku. "Urashima no hanashi”" (1910-1917, Ministry of Education Designated textbook, $2^{\text {nd }}$ edition), Shōgaku Dokuhon Binran, vol. 6. Tokyo: Musashino Shoin, 1983.}

In: Miura, Sukeyuki. Urashima Tarō no bungakushi. Tokyo: Goryū Shoin, 1989, pp. 22-23.

Once upon a time, there was a person called Urashima Tarō.

One day, when Urashima Tarō went to the beach, a lot of children had caught a turtle and were playing with it like a toy. Urashima felt sorry for it, so he bought the turtle from the children, and released it into the sea.

A couple of days later, when Urashima was fishing at the seashore, a big turtle came up to the surface and said, "Mr Urashima, thank you so much for the other day. I will take you to the Sea Palace in return for your kindness. Please climb onto my back." Urashima was delighted to ride on the turtle's back, then the turtle gradually sank deep under the sea and before long they arrived at the gate of the Sea Palace.

There was a beautiful princess called Otohime in the Sea Palace. She was delighted by Urashima's visit, offered him a feast and presented him with entertainments.

Urashima enjoyed it so much that he became a guest at the Sea Palace and forgot to return home.

But you soon tire of feasting every day, and even watching entertaining theatre every day becomes tedious. In due course, Urashima started to want to return home. So

\footnotetext{
${ }^{295}$ It seems that Iwaya misunderstood the translation from Otogizōshi, hence it became the sentence like this, which is not clear why does this part "happy".
} 
one day, Urashima said to the princess, "Thank you for looking after me. I have been here for such a long time, I think it is time I went home now."

"I hate to say goodbye and I will miss you so much. So, I will give you this treasure box as a memento. However, you should never open it, no matter what happens," said the princess, and she presented him with a beautiful box.

Urashima accepted the treasure box, rode on the turtle's back again, and came up to the sea's surface.

When he returned home, he was astonished; his father and mother had passed away, his own house was no longer there, all of his friends were gone. There was no one he recognised. He was so sad he could not stand it. He was so sad, that so he forgot what the princess said to him and opened the treasure box. When he opened the box, white smoke puffed out from the box, and Urashima suddenly became an old man with grey hair.

\section{Furuta, Tōsaku. “Urashima Tarō” (1918-1932, Ministry of Education Designated textbook, $3^{\text {rd }}$ edition), Shōgaku Dokuhon Binran, vol. 6. Tokyo: Musashino Shoin, 1983.}

In: Miura, Sukeyuki. Urashima Tarō no bungakushi. Tokyo: Goryū Shoin, 1989, pp. 22-23.

Once upon a time, there was a person called Urashima Tarō.

One day, when Urashima Tarō passed by the beach, a group of children had caught a turtle and were playing with it like a toy. Urashima felt sorry for it and he bought the turtle from the children, and released it into the sea.

A couple of days later, when Urashima was fishing from his boat, a big turtle came up to the surface and said, "Mr Urashima, thank you so much for the other day. I will take you to the Sea Palace in return for your kindness. Please climb on to my 
back." Urashima was delighted to ride on the turtle's back, then the turtle gradually went deep under the sea and before long they arrived at the Sea Palace.

The princess in the Sea Palace was delighted by Urashima's visit, and every day she offered him feasts and presented him with entertainments.

Urashima enjoyed it so much that he forgot to return home. But in due course Urashima started to want to return home. So Urashima said to the princess. "Thank you for looking after me. I have been here for such a long time, I think it is time for me to take my leave."

"I hate to say goodbye and I will miss you so much. So, I will give you this treasure box. Never open the lid, no matter what happens," said the princess, and she presented him with a beautiful box.

Urashima accepted the treasure box, rode on the turtle's back again, and came up to the sea's surface.

When he returned to his home, he was astonished: his father and mother had passed away and the village looked completely different. He did not recognised a single person. He was so sad he could not stand it, so he forgot what the princess said to him and opened the treasure box. When he opened the box, white smoke puffed out from the box and in an instant Urashima suddenly became an old man with grey hair.

14) Dazai, Osamu. “Urashima san”, Otogizōshi. Tokyo: Shinchō Bunko, 1972, pp.236-277.

Refer to: Dazai, Osamu. McCarthy, Ralph F (trans.). Otogizōshi: the fairy tale book of Dazai Osamu. Fukuoka: Kurodahan Press, 2011, pp. 23-65. 


\section{5) Matsutani, Miyoko illustrated by Iwasaki, Chihiro. Urashima Tarō. Tokyo: Kaiseisha, 1967.}

Matsutani, Miyoko illustrated by Iwasaki, Chihiro. Tresselt, Alvin (trans.). The fisherman under the sea. New York: Parents' Magazine Press, 1969.

In a time long ago there lived a handsome young man named Taro Urashima. He was a fisherman, and he lived in a village near the sea. Each day he put out in his boat to catch fish to sell in the market. And in this way he earned his living.

It so happened one day he sailed out to sea as usual, but in the whole day he did not catch so much as one fish. Returning that night he came upon a group of noisy children gathered around a little turtle. They were having great fun, banging on the poor creature's shell and swinging it by the tail.

Taro's heart was touched with pity when he saw this, and he begged the children to release the turtle. Somewhat ashamed of their unkind behaviour, the children handed the turtle to him and ran off down the beach. The fisherman now looked more closely at the turtle and was surprised to discover that it was like no other he had ever seen. Its shell glowed with the pure colors of the rainbow. At length he put the turtle down by the edge of the water, and the creature quickly crawled into the protecting waves. Taro watched. Then, just as he returned to leave, the turtle appeared and solemnly nodded its head as if to say thank you.

The next day Taro set out again to fish. "Let us hope that today brings greater fortune than yesterday," he said as he lowered his nets into the water. But at that instant a huge turtle appeared at the edge of the boat. Bowing his head he spoke to the startled fisherman. "I have come to thank you for saving the life of a small turtle," he said. "I have been told by my master, the King of the Sea, to take you down to his Dragon Palace so that he may thank you also. Would you be so kind as to climb upon my back?" Taro was so surprised by this strange request that he did not think to do otherwise. He jumped from his boat and quickly seated himself on the turtle's back, slippery with sea moss. Slowly the creature turned around, then dove down, down into the blue-green water of the sea. 
Taro was surrounded by beautifully colored fish of every shape and size, and strange seaweeds floated in the water about him. Soon they were in an underwater land of great mountains and valleys. Then in the distance the shining walls of a palace appeared. It was the Dragon Palace of the King of the Sea.

On through groves of coral trees they went, while brilliant fish darted in an out among the red and pink branches like birds. At last they arrived at the great gate of the palace itself. The building with its coral pillars and a roof of delicate sea shells shimmered in the rippling water.

Taro Urashima gasped with astonishment. Never had the simple fisherman ever seen anything so beautiful. Servants appeared at the doorway to welcome him, and to the sound of distant music he was ushered into the halls of the palace.

Leading the way, the servants conducted Taro from one room to another, each more splendid than the last, until finally he was shown into the throne room. There before him sat the King of the Sea. At once Taro bowed low before such a magnificent sight. "Do not bow before me," said the kind kindly. "I have had you brought here so that I might thank you for saving the life of my daughter. May you have many happy days living in my palace as her husband." With this a young girl approached Taro and bowed before him. "I was the small turtle you rescued from the children," she said, and her voice was like the tinkling of far-off bells.

Taro was speechless before such beauty. The princess moved with the suppleness of a blade of sea grass waving in the water, and her smile was as gentle as the sea waves on a calm day.

Seeing the question in Taro's eyes she said, "I had never left my home here in the Dragon Palace, and I was curious to see the people who live on the land. I changed myself into a little turtle and swam to the shore of your country. But, alas, I had no sooner crawled up on the beach when I was found by those children. If you had not rescued me from them, I am afraid my fate would have been a sad one." Before Taro could answer she went on. "But I forget. You must be hungry after your long journey." She waved her hand and there suddenly appeared a table laden with all manner of delicious foods. 
In all his born days Taro had never tasted such food. The rice wine was the color of amber washed up by the sea, the fish was delicately flavoured with strange herbs, and the pastries were as light and fragile as snowflakes. The dishes were of the finest gold and silver, and the food was served in lacquer bowls of glowing red. Taro had scarcely begun to eat when the princess waved her hand again. At once beautiful dancing girls appeared to entertain him, and the sound of music filled the hall.

When the feast was over, the princess took him by the hand and led him on and on through the countless rooms of the palace. Presently they came to a large window looking out upon broad fields.

It was spring, and Taro could see the farmers busily planting the young rice in the flooded paddies. But even as he looked the plants grew instantly, and the countryside changed from the fresh green of springtime to the richer green of midsummer. He had no sooner marvelled at this when he saw that the rice plants were bent over, heavy with the weight of ripened grain, and autumn had come. Scarcely was the grain harvested when the snows of winter were falling. In no more than a minute a whole year had appeared before his eyes!

And so the time passed for Taro in the Dragon palace beneath the sea. Never had he been so happy. The lovely princess became his wife and his constant companion. There were servants at his beck and call to fulfil his slightest wish. One day followed another, and whether it was real or just a dream he could not tell.

But one day in a quiet moment, Taro suddenly recalled his fishing boat, and the joy of pulling nets filled with fish up out of the sea. He thought of his mother and his friends in the village. How he would like to see them all, and tell his life here in the palace! Going to the princess he told her of his desire to see his village once more.

She tried to persuade him to stay, but at last, seeing that Taro was determined to go, she sadly agreed to let him leave. "But take this with you," she said, handing him a box of finest red lacquer. "As long as you keep this safe, you will always be able to come back to me." Then she paused. "But remember - you must never open the box to see what is in it." Taro embraced his wife and assured her that he would return. Then, with the blessings of the King of the Sea, he set out from the Dragon Palace. 
Once more Taro mounted the back of the old turtle and began the journey to his own land. Quickly the shining walls of the palace disappeared from view. Through the valleys and past the mountains they went, then up, to the surface of the sea, and there before him Taro saw again the houses of his village beside the sea.

He thanked the turtle for his safe trip, then ran up the beach toward his village. But something was wrong! The familiar shape of the mountain behind the village was still there, but the streets and houses all looked different. Taro wandered through the strange streets to where his house should have been, but there was a building he had never seen before. Going up to a villager he asked, "Is this not the place where Taro Urashima lives?" The man looked at him with surprise. "Taro Urashima's house rotted and fell down many years ago," he replied.

"When I was a boy my grandfather told me a story that his grandfather had told him," he said. "Taro went off fishing one morning and was never seen again. His boat was found, but not Taro. People believed that the sea demons had stolen him away." With a word of thanks, Taro turned from the man and wandered back to the seashore. How many years had he spent living in the Dragon Palace? A hundred? Two hundred? But here he was, still a young man! He was filled with loneliness, and his eyes fell on the red lacquer box. Perhaps the answer to all this was in the box. And forgetting what the princess had told him, Taro loosened the silken cords and opened it. A puff of white smoke appeared as he lifted the lid, and instantly he became a shaky old man with white hair and a long white beard.

Then faintly from over the water he heard the sad voice of the princess. "Oh, Taro, Taro, my husband, my beloved. You promised me you would never open the box," she cried. "It was your life I had shut up so that you would never grow old. Farewell, Taro, farewell." And the voice of the princess was lost in the sound of the sea waves crashing on the shore at the old man's feet. 


\section{References:}

Adolphson, Mikael, Kamens, Edward, and Matsumoto, Stacie. Heian Japan, centers and peripheries. Honolulu: University of Hawai'i Press, 2007.

Araki, James T. Otogi-Zoshi and Nara-Ehon: A Field of Study in Flux. Monumenta Nipponica, Vol. 36, No. 1 Spring, 1981, pp. 1-20.

<http://www.jstor.org.helicon.vuw.ac.nz/stable/pdfplus/2384084.pdf?\&acceptT $\mathrm{C}=$ true \&jpdConfirm $=$ true $>$. Accessed on $16^{\text {th }} \mathrm{Jan}, 2014$.

Aston, W. G. Nihongi, volume 1-chronicles of Japan from the earliest times to A.D. 697. New York: Cosimo, 2008. (Originally published in 1896.)

Bentley, John R. The authenticity of Sendai kuji hongi: a new examination of texts, with a translation and commentary. Boston, Leiden: Brill, 2006.

Chibbett, David. The history of Japanese printing and book illustration. Tokyo, New York, San Francisco: Kōdansha International Ltd, 1977.

Cranston, Edwin A. A Waka Anthology, volume one: The Gem-Glistening Cup, Translated wih a commentary and notes. Stanford, California: Stanford University Press, 1993.

Daijirin, $3^{\text {rd }}$ ed. (Matsumura, Akira. Tokyo: Sanseidō, 2006). “Asuka Jidai.” Kotobank, Yahoo Japan Dictionary, (C) 2013 The Asahi Shimbun Company/VOYAGE GROUP, Inc. <http://kotobank.jp/word/\%E9\%A3\%9B\%E9\%B3\%A5\%E6\%99\%82\%E4\%BB $\%$ A3?dic=daijirin\&oid=DJR_asuka_-010-_zidai_-01Tokyo:>. Accessed on $10^{\text {th }}$ Dec, 2013.

Daijirin, $3^{\text {rd }}$ ed. (Matsumura, Akira. Tokyo: Sanseidō, 2006). “Gi.” Kotobank, Yahoo Japan Dictionary, (C) 2014 The Asahi Shimbun Company/VOYAGE GROUP, Inc. <http://kotobank.jp/word/\%E9\%AD\%8F?dic=daijisen>. Accessed on $8^{\text {th }}$ Jan, 2014.

Daijirin, $3^{\text {rd }}$ ed. (Matsumura, Akira. Tokyo: Sanseidō, 2006). “Hakuhō Jidai.” Kotobank, Yahoo Japan Dictionary, (C) 2013 The Asahi Shimbun Company/VOYAGE GROUP, Inc. 
$<$ http://kotobank.jp/word/\%E7\%99\%BD\%E9\%B3\%B3\%E6\%99\%82\%E4\%BB $\%$ A3?dic=daijirin\&oid=DJR_Hakuhō_-020-_zidai_-01>. Accessed on $13^{\text {th }}$ Dec, 2013.

Daijirin, $3^{\text {rd }}$ ed. (Matsumura, Akira. Tokyo: Sanseidō, 2006). "Hakushimonjū." Kotobank, Yahoo Japan Dictionary, (C) 2014 The Asahi Shimbun Company/VOYAGE GROUP, Inc.

<http://kotobank.jp/word/\%E7\%99\%BD\%E6\%B0\%8F\%E6\%96\%87\%E9\%9B $\% 86$ ?dic=daijirin\&oid=DJR_hakusimonnjuu_-010>. Accessed on $13^{\text {th }} \mathrm{Jan}$, 2014.

Daijirin, $3^{\text {rd }}$ ed. (Matsumura, Akira. Tokyo: Sanseidō, 2006). “Kojidan.” Kotobank, Yahoo Japan Dictionary, (C) 2013 The Asahi Shimbun Company/VOYAGE GROUP, Inc.

$<$ http://kotobank.jp/word/\%E5\%8F\%A4\%E4\%BA\%8B\%E8\%AB\%87?dic=seka idaihyakka\&oid=00169819>. Accessed on $16^{\text {th }}$ Dec, 2013.

Daijirin, $3^{\text {rd }}$ ed. (Matsumura, Akira. Tokyo: Sanseidō, 2006). “Ryōunshū.” Kotobank, Yahoo Japan Dictionary, (C) 2013 The Asahi Shimbun Company/VOYAGE GROUP, Inc.

$<$ http://kotobank.jp/word/\%E5\%87\%8C\%E9\%9B\%B2\%E9\%9B\%86?dic=daijiri n\&oid=DJR_ryouunnsyuu_-010>. Accessed on $16^{\text {th }}$ Dec, 2013.

Daijirin, $3^{\text {rd }}$ ed. (Matsumura, Akira. Tokyo: Sanseidō, 2006). "Shoku Nihongi." Kotobank, Yahoo Japan Dictionary, (C) 2013 The Asahi Shimbun Company/VOYAGE GROUP, Inc.

<http://kotobank.jp/word/\%E7\%B6\%9A\%E6\%97\%A5\%E6\%9C\%AC\%E7\%B4 $\% 80$ ?dic=daijirin\&oid=DJR_syokunihonngi_-010>. Accessed on $16^{\text {th }}$ Dec, 2013.

Daijirin, $3^{\text {rd }}$ ed. (Matsumura, Akira. Tokyo: Sanseidō, 2006). “Shijin.” Kotobank, Yahoo Japan Dictionary, (C) 2014 The Asahi Shimbun Company/VOYAGE GROUP, Inc.

<http://kotobank.jp/word/\%E5\%9B\%9B\%E7\%A5\%9E?dic=daijisen\&oid=0800 2100>. Accessed on $18^{\text {th }}$ Jan, 2014. 
Dazai, Osamu (author), and Okuno Takeo (commentary). Otogizōshi. Tokyo: Shinchōsha, 1972.

Dazai, Osamu. Otogizōshi: the fairy tale book of Dazai Osamu, translated by McCarthy, Ralph F. Fukuoka: Kurodahan Press, 2011.

Digital Daijisen. (Matsumura, Akira. Tokyo: Shōgakukan, 2013). "Emperor Horikawa." Kotobank, Yahoo Japan Dictionary, (C) 2014 The Asahi Shimbun Company/VOYAGE GROUP, Inc.

$<$ http://kotobank.jp/word/\%E5\%A0\%80\%E6\%B2\%B3\%E5\%A4\%A9\%E7\%9A $\% 87>$. Accessed on $18^{\text {th }}$ Feb, 2014.

Digital Daijisen. (Matsumura, Akira. Tokyo: Shōgakukan, 2013). "Fusōryakki." Kotobank, Yahoo Japan Dictionary, (C) 2014 The Asahi Shimbun Company/VOYAGE GROUP, Inc.

<http://kotobank.jp/word/\%E6\%89\%B6\%E6\%A1\%91\%E7\%95\%A5\%E8\%A8 $\% 98$ ?dic $=$ daijisen\&oid $=16119000>$. Accessed on $18^{\text {th }}$ Feb, 2014.

Digital Daijisen. (Matsumura, Akira. Tokyo: Shōgakukan, 2013). "Ōhashi Shintarō." Kotobank, Yahoo Japan Dictionary, (C) 2014 The Asahi Shimbun Company/VOYAGE GROUP, Inc. <http://kotobank.jp/word/大橋新太 郎?dic=daijisen\&oid=02229600 $>$. Accessed on $27^{\text {th }}$ Aug, 2014.

Digital Daijisen. (Matsumura, Akira. Tokyo: Shōgakukan, 2013). "Otogizōshi." Kotobank, Yahoo Japan Dictionary, (C) 2014 The Asahi Shimbun Company/VOYAGE GROUP, Inc. <http://kotobank.jp/word/\%E5\%BE\%A1\%E4\%BC\%BD\%E8\%8D\%89\%E5\%A D\%90?dic=daijisen\&oid=02452500>. Accessed on $13^{\text {th }}$ Jan, 2014.

Duus, Peter (ed.). The Cambridge history of Japan, Volume 6 The Twentieth Century. Cambridge; New York: Cambridge University Press, 1990.

Eberhard, Wolfram; trans. G. L. Campbell. A dictionary of Chinese symbols: hidden symbols in Chinese life and thought. London: Routledge, 1986.

Encyclopædia Britannica online, “Chikamatsu Monzaemon.” @2014 Encyclopædia Britannica, Inc. 
<http://www.britannica.com/EBchecked/topic/110980/ChikamatsuMonzaemon>. Accessed on 23 $3^{\text {rd }}$ Jan, 2014.

Encyclopædia Britannica online, “Dazai Osamu.” (C2014 Encyclopædia Britannica, Inc. 〈http://www.britannica.com/EBchecked/topic/153214/Dazai-Osamu> . Accessed on $27^{\text {th }}$ Jan, 2014.

Encyclopædia Britannica online, “Japan.” (C2014 Encyclopædia Britannica, Inc. <http://www.britannica.com/EBchecked/topic/300531/Japan/23184/Japan-from1850-to-1945?anchor=ref319654>. Accessed on 22 ${ }^{\text {nd }}$ Jan, 2014.

Encyclopædia Britannica online, “Japanese literature.” @2014 Encyclopædia Britannica, Inc.

<http://www.britannica.com/EBchecked/topic/301194/Japaneseliterature/61857/The-Muromachi-1338-1573-and-Azuchi-Momoyama-15741600-periods?anchor=ref319902>. Accessed on 16 ${ }^{\text {th }}$ Jan, 2014.

Encyclopædia Britannica online, “Jitō.” (C2014 Encyclopædia Britannica, Inc. <http://www.britannica.com/EBchecked/topic/304067/jito>. Accessed on $16^{\text {th }}$ Jan, 2014.

Encyclopædia Britannica online, “Jōruri.” @2014 Encyclopædia Britannica, Inc. $<$ http://www.britannica.com/EBchecked/topic/306273/joruri $>$. Accessed on $23^{\text {rd }}$ Jan, 2014.

Encyclopædia Britannica online, "Kaifūsōo," (C2013 Encyclopædia Britannica, Inc. <http://www.britannica.com/EBchecked/topic/309757/Kaifuso>. Accessed on $16^{\text {th }}$ Dec, 2013.

Encyclopædia Britannica online, “Meiji." @2014 Encyclopædia Britannica, Inc. $<$ http://www.britannica.com/EBchecked/topic/373294/Meiji $>$. Accessed on 22 $2^{\text {nd }}$ Jan, 2014.

Encyclopædia Britannica online, “shugo.” @2014 Encyclopædia Britannica, Inc. <http://www.britannica.com/EBchecked/topic/304067/jito>. Accessed on $16^{\text {th }}$ Jan, 2014. 
Encyclopædia Britannica online, “The Setting Sun.” (C2014 Encyclopædia Britannica, Inc. <http://www.britannica.com/EBchecked/topic/1782715/The-Setting-Sun>. Accessed on $28^{\text {th }}$ April, 2014.

Endō, Hiroshi. "Takahashi no Mushimaro.” Shōgakukan, Nihon Daihyakka Zenshū, Yahoo Japan.

<http://100.yahoo.co.jp/detail/\%E9\%AB\%98\%E6\%A9\%8B\%E8\%99\%AB\%E9 $\%$ BA\%BB\%E5\%91\%82/\#header>. Accessed on $25^{\text {th }}$ Sep, 2013.

Fukunaga, Mitsuji. Dōkyō to Kodai Nihon. Kyoto: Jimbunshoin, 1987.

Hall, John Whitney (ed.), and McClain, James L (assistant editor). The Cambridge history of Japan, Volume 4 Early Modern Japan. Cambridge; New York: Cambridge University Press, 1990.

Halpern, Jack. New Japanese-English character dictionary. Tokyo: Kenkyūsha, 1990.

Henshall, Kenneth. A history of Japan, from stone age to superpower, $2^{\text {nd }}$ edition. New York: Palgrave Macmillan, 2004.

Hino, Takuya. "Ocean of Suffering, Boat of Compassion: A Study of the Fudaraku Tokai and Urashima in Anecdotal (Setsuwa) Literature." Journal of the American Academic of Religion, 80, 4, 2014, pp. 1049-1076, doi:10.1093/jaarel/lfs081.

Hitachi Solutions Business, Ltd. Hyakkajiten Maipedia. “Shishin.” Kobobank, Yahoo Japan Dictionary, 2010. (C) 2013 Hitachi Solutions Business, Ltd. <http://kotobank.jp/word/\%E5\%9B\%9B\%E7\%A5\%9E?dic=sekaidaihyakka\&oi $\mathrm{d}=00187544>$. Accessed on $30^{\text {th }}$ April, 2014.

Honda, Akari. Ryūtei Tanehiko, Yomihon no miryoku. Kyoto: Rinsen shoten, 2006.

Ichiko, Teiji. Otogizōshi (ge). Tokyo: Iwanami Shoten, 2010.

Inukai, Takashi. Manyō no kajin, Takahashi no Mushimaro. Kyoto: Sekaishisōsha, 1997.

Jansen, Marius B (ed.). The Cambridge history of Japan, Volume 5 The Nineteenth Century. Cambridge; New York: Cambridge University Press, 1990. 
Keene, Donald. The Manyōshū, The Nippon Gakujutsu Shinkōkai Translation of one thousand poems. New York: Columbia University, 1969.

Kimishima, Hisako. Tsuki o kajiru inu. Tokyo: Chikuma shobō, 1984.

Kindaichi, Haruhiko. Hirano, Umeyo (trans. and annot.). The Japanese Language. Tokyo: Tuttle Publishing, 1978.

Knapp, Keith. “Ge Hong”. Internet Encyclopaedia of Philosophy IEP, A PeerReviewed Academic Resource. Fieser, James, and Dowden, Bradley. Last updated: July 9, 2005. Originally published: November/14/2003. <http://www.iep.utm.edu/gehong/>. Accessed on $1^{\text {st }}$ June, 2013.

Kodama, Kōta. Nihonshi Nenpyō, Chizu. Tokyo: Yoshikawa Kōbunkan, 2013. (First published in 1995.)

Kogawa, Hiroshi. Kokuteikyōkasho. Tokyo: Shinchōsha, 1985.

Kumar, Ann. Globalizing the prehistory of Japan: language, genes and civilization. London; New York: Routledge, 2009.

Lurie, David B. Realm of Literacy: Early Japanese and the History of Writing. Cambridge, Mass.: Harvard University Asia Center, 2011.

Manyōshū Kōhon data base sakusei iinkai. "Suminoe.” Manyōshū, Manyōshū Kōhon data base. <http://www.manyou.gr.jp/SMAN_1/pass/09/kaku.cgi?kaku=1740003>. Accessed on $13^{\text {th }}$ Dec, 2013.

Marceau, Lawrence E. "Behind the scenes: narrative and self-referentiality in Edo illustrated popular fiction". Japan Forum, 21, 3, 2010, pp. 403-423, DOI: $10.1080 / 09555801003773661$.

Mass, Jeffery. The Kamakura Bakufu: A study in documents, foreword by Takeuchi Rizō. California: Stanford University Press, 1976.

Matsumoto, Ryushin. “Textual Criticism of Koatsumori (小敦盛) and Yokobue-sōshi (横笛草紙) (Otogi Sōshi of Shibukawa Edition) compared with their old 
Manuscripts [in Japanese].”Shidō Bunko Ronshū (斯道文庫論集) 2.3, 1963, pp. 171-242.

Matsutani, Miyoko, illustrated by Iwasaki, Chihiro. Tresselt, Alvin (trans.). The fisherman under the sea. New York: Parents' Magazine Press, 1969.

Matsutani, Miyoko, illustrated by Iwasaki, Chihiro. Urashima Tarō. Tokyo: Kaiseisha, 1967.

Mifune, Takayuki. Urashima Tarō no Nihonshi. Tokyo: Yoshikawa Kōbunkan, 2009.

Miura, Sukeyuki. Kōgoyaku, Kojiki, Kanzemban. Tokyo: Bungei shunjū, 2002.

Miura, Sukeyuki. Nihon Kodai Bungaku Nyūmon. Tokyo: Gentōsha, 2006.

Miura, Sukeyuki. Urashima Tarō no Bungakushi. Tokyo: Goryūshoin, 1989.

Miyake, Marc Hideo. Old Japanese: A Phonetic Reconstruction. London and New York: RoutledgeCurzon, 2003.

Momose, Kesao. “Gunshoruijū”, Shōgakukan, Nihon Daihyakka Zenshū, Yahoo Japan. $<$ http://100.yahoo.co.jp/detail/\%E7\%BE\%A4\%E6\%9B\%B8\%E9\%A1\%9E\%E5 $\%$ BE\%93/>. Accessed on $8^{\text {th }}$ Oct, 2013.

Morohashi, Tetsuji. Dai Kanwa jiten $3^{\text {rd }}$ ed. index, vol.13. Tokyo: Taishūkan Shoten, 1971. (First published in 1955.)

Morohashi, Tetsuji. Dai Kanwa jiten $3^{\text {rd }}$ ed. 12 vols. Tokyo: Taishūkan Shoten, 1971. (First published in 1955.)

Nakano, Mitsutoshi, and Hida, Kouzou. Kinsei kodomo no ehon shü, kamigata hen. Tokyo: Iwanami Shoten, 1985.

Ōbayashi, Taryō, Yoshida, Atsuhiko, and Aoki, Shūhei. Nihon shinwa jiten. Tokyo: Daiwa Shobō, 1997.

Oboroya, Hisashi. “Fusōryakki.” Shōgakukan, Nihon Daihyakka Zenshū, Yahoo Japan. <http://100.yahoo.co.jp/detail/\%E6\%89\%B6\%E6\%A1\%91\%E7\%95\%A5\%E8\% A8\%98/>. Accessed on $15^{\text {th }}$ Oct, 2013. 
Ooms, Herman. Imperial Policics and Symbolics in Ancient Japan: The Tenmu Dynasty, 650-800. Honolulu: University of Hawaii Press, 2009.

Ōshima, Tatehiko (annot. and trans.). Nihon koten bungaku zenshu, vol. 36. Otogizōshi shū. Tokyo: Shōgakukan, 1974.

Palmer, Edwina. "A poem to carp about? Poem 16-3828 of the Man’yōshū collection." Bulletin of SOAS (School of Oriental and African Studies), University of London, 74, 3, 2011, pp. 417-136.

Palmer, Edwina. "The "Womë-No" Poem of "Harima Fudoki" and Residual Orality in Ancient Japan.” Bulletin of the SOAS (School of Oriental and African Studies), University of London, 63, 1, 2000, pp. 81-89.

$<$ http://www.jstor.org/stable/1559589>. Accessed on 22 ${ }^{\text {nd }}$ Feb, 2014.

Plutschow, Herbert. A reader in Edo Period travel. Folkestone, Kent, U.K.: Global Oriental, 2006.

Progressive waeichū jiten, $3^{\text {rd }}$ ed. (Kondō, Ineko and Takano, Fumi main editors, Shōgakukan.) "shonanoka”. Kotobank, Yahoo Japan Dictionary, (C) 2014 The Asahi Shimbun Company/VOYAGE GROUP, Inc. $<$ http://kotobank.jp/jeword/\%E5\%88\%9D\%E4\%B8\%83\%E6\%97\%A5\%E5\%BF $\% 8 C$ ?dic=pje3\&oid=SPJE02086800>. Accessed on 20 $0^{\text {th }}$ Jan, 2014.

Satō, Takeyoshi. Gaisetsu, Nihongo no rekishi. Tokyo: Asakura shoten, 1995.

Sakaguchi, Tamotsu. Urashima setsuwa no kenkyū. Osaka: Shingensha, 1955.

Sekai Daihyakka Jiten, $2^{\text {nd }}$ ed. (Katō, Shūichi. Tokyo: Heibonsha, 2006).

“Bunkashūreishū." Kotobank, Yahoo Japan Dictionary, (C) 2013 Hitachi Solutions Business, Ltd.

<http://kotobank.jp/word/\%E6\%96\%87\%E8\%8F\%AF\%E7\%A7\%80\%E9\%BA $\% 97 \%$ E9\%9B\%86?dic=sekaidaihyakka\&oid $=00298825>$. Accessed on $16^{\text {th }}$ Dec, 2013.

Sekai Daihyakka Jiten, $2^{\text {nd }}$ ed. (Katō, Shūichi. Tokyo: Heibonsha, 2006). “Dōteiko." Kotobank, Yahoo Japan Dictionary, (C) 2013 Hitachi Solutions Business, Ltd. 
<http://kotobank.jp/word/\%E6\%B4\%9E\%E5\%BA\%AD\%E6\%B9\%96?dic=seka idaihyakka\&oid $=00251560>$. Accessed on $28^{\text {th }}$ April, 2014.

Sekai Daihyakka Jiten, $2^{\text {nd }}$ ed. (Katō, Shūichi. Tokyo: Heibonsha, 2006). “Kojidan." Kotobank, Yahoo Japan Dictionary, (C) 2013 Hitachi Solutions Business, Ltd. <http://kotobank.jp/word/\%E5\%8F\%A4\%E4\%BA\%8B\%E8\%AB\%87?dic=daiji rin\&oid=DJR_kozidann_-010>. Accessed on $16^{\text {th }}$ Dec, 2013.

Sekai Daihyakka Jiten, $2^{\text {nd }}$ ed. (Katō, Shūichi. Tokyo: Heibonsha, 2006). "Nara Ehon.” Kotobank, Yahoo Japan Dictionary, (C) 2013 Hitachi Solutions Business, Ltd.

<http://kotobank.jp/word/\%E5\%A5\%88\%E8\%89\%AF\%E7\%B5\%B5\%E6\%9C $\%$ AC ?dic=daijisen\&oid $=13862400>$. Accessed on $23^{\text {rd }}$ Apr, 2014.

Sekai Daihyakka Jiten, $2^{\text {nd }}$ ed. (Katō, Shūichi. Tokyo: Heibonsha, 2006). "Seiōbo." Kotobank, Yahoo Japan Dictionary, (C) 2013 Hitachi Solutions Business, Ltd. $<$ http://kotobank.jp/word/\%E8\%A5\%BF\%E7\%8E\%8B\%E6\%AF\%8D?dic=daiji sen\&oid $=10101200>$. Accessed on $24^{\text {th }}$ Jan, 2014.

Sekai Daihyakka Jiten, $2^{\text {nd }}$ ed. (Katō, Shūichi. Tokyo: Heibonsha, 2006). "Shirei." Kotobank, Yahoo Japan Dictionary, (C) 2013 Hitachi Solutions Business, Ltd. <http://kotobank.jp/word/\%E5\%9B\%9B\%E9\%9C\%8A>. Accessed on $21^{\text {st }} \mathrm{Feb}$, 2014.

Sekai Daihyakka Jiten, $2^{\text {nd }}$ ed. (Katō, Shūichi. Tokyo: Heibonsha, 2006). “Teiō Hennenki.” Kotobank, Yahoo Japan Dictionary, (C) 2013 Hitachi Solutions Business, Ltd. $<$ http://kotobank.jp/word/\%E5\%B8\%9D\%E7\%8E\%8B\%E7\%B7\%A8\%E5\%B9 $\%$ B4\%E8\%A8\%98?dic=sekaidaihyakka\&oid=00243412>. Accessed on $13^{\text {th }}$ Dec, 2013.

Sekai Daihyakka Jiten, $2^{\text {nd }}$ ed. (Katō, Shūichi. Tokyo: Heibonsha, 2006). "Yūryaku Tennō." Kotobank, Yahoo Japan Dictionary, (C) 2013 Hitachi Solutions Business, Ltd.

<http://kotobank.jp/word/\%E9\%9B\%84\%E7\%95\%A5\%E5\%A4\%A9\%E7\%9A $\% 87$ ?dic $=$ sekaidaihyakka\&oid=00330151>. Accessed on $10^{\text {th }}$ Dec, 2013. 
Senda, Minoru hen. Kanshinakai Bunka to Kodai Nihon, Dōkyo to Sono Shūhen. Kyoto: Jimbun shoin, 1990.

Shigematsu, Akihisa. Urashimako Den (on demand version). Tokyo: Gendaishichōshinsha, 2006. (First published in 1981.)

Shimauchi, Keiji. Otogizōshi no seishinshi. Tokyo: Perikan sha, 1991.

Shimmura, Izuru. Kōjien, $4^{\text {th }}$ ed. Tokyo: Iwanami Shoten, 1993.

Shimode, Sekiyo. Shinsen shisō. Tokyo: Yoshikawa Kōbunkan, 1968.

Shinchōsha Publishing. Ibuse Masuji. Shinchōsha Publising Co, Ltd. <https://www.shinchosha.co.jp/writer/863/>. Accessed on $24^{\text {th }}$ Feb, 2014.

Someya, Hiroko. ""Otogizoshi" and Its Denomination [in Japanese].” Human relations and culture review 2. 3, 2004, pp. 62-44.

Sumiyoshi Taisha. "About a history and a tradition of Sumiyoshi Taisha". Sumiyoshi Taisha official website.

<http://www.sumiyoshitaisha.net/dictionary/faq_sumi.html\#no06.>. Accessed on $13^{\text {th }}$ Dec, 2013.

Sumiyoshi Taisha. “Aramashi”. Sumiyoshi Taisha official website.

$<$ http://www.sumiyoshitaisha.net/outline/outline.html>. Accessed on $5^{\text {th }}$ May, 2013.

Sumiyoshi Taisha. "Gūji aisatsu”. Sumiyoshi Taisha official website. $<$ http://www.sumiyoshitaisha.net/outline/message.html>. Accessed on $5^{\text {th }}$ May, 2013.

Suzuki, Jūzō, and Kimura, Yaeko (ed). Kinsei kodomo no ehon shū, edo hen. Tokyo: Iwanami Shoten, 1985.

Tada, Gen. Mōichido manabitai Kojiki to Nihonshoki. Tokyo: Seitousha, 2008.

Takagi, Ichinosuke, Gomi, Tomohide, and Ōno, Susumu (annot.). Manyōshū 2, Nihon Koten Bungaku Taikei vol. 5. Tokyo: Iwanami Shoten, 1959. 
Takahashi, Tōru, and Senda, Minoru. Nihonshi o irodoru dōkyō no nazo. Tokyo: Nihonbungeisha, 1991.

Takioto, Noriyuki. “浦島子伝承の変容 Urashimako denshō no henyō. [The Transformation of a Folktale called Urashimashi]." The Journal of the Historical Association of Komazawa University 56, 2000, pp. 1-37.

Tanigawa, Kenichi. Kodai ama no sekai. Tokyo: Shōgakukan, 1995.

The Rengein Tanjōji Temple. "The history of Rengein Tanjoji Temple". The Rengein Tanjōji Temple home page. 〈http://www.rengein.jp/about/english.php>. Accessed on 18th Feb, 2014.

Ueda, Nobumichi (koutei), [Iwaya, Sazanami (cho)]. Nippon Mukashibanashi. Tokyo: Heibonsha, 2001.

Uegaki, Setsuya. Fudoki. Tokyo: Shōgakukan, 1997.

Varley, H. Paul. Japanese Culture. London: Faber and Faber Limited, 1973.

Yamamura, Kōzō (ed). The Cambridge History of Japan, Volume 3 Medieval Japan. Cambridge; New York: Cambridge University Press, 1990.

Yan, Shaodang. Nihongo “denki” [Urashimako Den] no kenkyū. Tokyo: 1995, Kokusai Nihon Bunka Kenkyū Centre. 


\section{Bibliographies:}

Chikamatsu zenshū kankōkai. Chikamatsu zenshū, vol. 12. Tokyo: Iwanami Shoten, 1990.

Fujiki, Kunihiko. Nihon zenshi 3 Kodai II. Tokyo: Tokyo Daigaku Shuppankai, 1971.

Fukunaga, Mitsuji. Dōkyō to Nihonbunka. Kyoto: Jimbunshoin, 1982.

Gordon, Andrew. A modern history of Japan, from Tokugawa times to the present. New York; Oxford: Oxford University Press, 2003.

Hadamitzky, Wolfgang, and Smith, Mark. Kanji \& kana, a handbook of the Japanese writing system revised edition. Tokyo: Charles E. Tuttle Publishing, 1981.

Hara, Masako. "The possessions and changes of Tarō Urashima - The confluence between the origin of literature and the tide of Buddhism." Senri Kinran University Kiyō 7.1 21, 2010, pp. 1-21.

Honda, Heihachiro. The Manyōshū, a new and complete translation. Tokyo: Hokuseidō Press, 1967.

Ibaraki, Harue. Lost Fudoki Referred to in Shaku-Nihongi (part 4). Fudoki Research, $25,9,2000$, p.21.

Iijima, Shigeru. Nihon bunka no genzō: Shima no kokoro to tairikuteki ronri. Kyoto: Tankōsha, 1991.

Inada, Kōji [et al ed]. Nihon mukashibanashi jiten. Tokyo: Kōbundō, 1994.

Inoue, Mitsutada (sekinin henshū). Nihonshoki, Nihon no meicho. Tokyo: Chūōkōronsha, 1983.

Kanda, Norishiro ed. Fudoki no hyōgen, Kiroku kara bungaku e. Tokyo: Kasamashoin, 2009.

Kawakita, Noboru. Mizukagami Zenhyōshaku. Tokyo: Kasamashoin, 2011.

Kawamura, Teruo and Kobayashi, Kazuhiko. Mumyōshō, Kamo Chōmei (cho). Tokyo: Miyaishoten, 1998. 
Kawauchi, Sayumi ed. McCarthy, Ralph F, trans. Manga, Nihon Mukashibanashi Once Upon a Time in Japan. Tokyo: Kōdansha International, 1997.

Kimura, Yaeko, Uda, Toshihiko, and Koike, Masatane. Kusazōshi shū, Shin Nihon Koten Bungaku Taikei 83. Tokyo: Iwanami Shoten, 1997.

Kuroita, Katsumi and Kokushi Taikei Henshūkai. Kokushi taikei, Nihonshoki. Tokyo: Yoshikawa Kōbunkan, 1992.

Miyata, Noboru. Nihon "Shinwa densetsu"sōran. Tokyo: Shinjinbutsu Ōraisha, 1993.

Nakanishi, Susumu. Manyōshū, Zenyakuchū gembun tsuki. Tokyo: Kōdansha, 2007. (First published in 1980.)

Nakashima, Mayumi. "Change in the Inclusion of the Story of Urashima Tarō in Japanese-Language Educational Materials for Primary Schools”. Aichi Shukutoku University Ronshu - bungakubu, bungaku kenkyū hen 35. 3, 2010, pp. 57-58.

National Diet Library Digitalized Contents. "Otogizōshi, vol. 21 Urashima Tarō”. National Digital Library, 2011.

<http://dl.ndl.go.jp/info:ndljp/pid/2537589?itemId=info\%3Andljp\%2Fpid\%2F2 $537589 \&$ \&lang $=\mathrm{ja}>$. Accessed on $16^{\text {th }}$ Jan, 2014.

Ōbayashi, Taryō and Yoshida, Atsuhiko (ed.). Nihon shinwa jiten. Tokyo: Daiwa Shobō, 1997.

Ōchi, Yuriko, Sakō, Nobuyuki., and Tanaka, Hisao (author), Fukuda, Akira (ed.). Nihon densetsu taikei (vol. 8 Kita kinki hen). Tokyo: Mizuumi Shobō, 1988.

Omodaka, Hisataka. Manyōshū chūshaku, vol. 9. Tokyo: Chūōkōronsha, 1963.

Osada, Fumito. Urashma Tarō no nazo. Tokyo: Bungeisha, 2002.

Sakade, Florence, illustrated by Hayashi, Yoshio. Urashima Tarō, and other Japanese children's stories. Rutland, Vt.; Tokyo: Charles. E. Tuttle, 1964.

Sakae, Wataru. Kodaika kara miru Harima no Kuni Fudoki. Kobe: Nojigiku bunko, 2007. 
Sakamoto, Tarō, Ienaga, Saburō, Inoue, Mitsusada, and Ōno, Susumu. Nihonshoki (3). Tokyo: Iwanami Shoten, 2007. (First pubished in 1994.)

Sanseidō henshūjo. Atarashii kokugo hyōki handbook. Tokyo: Sanseidō, 1991.

Satake, Akihiro. Manyōshū, hombun hen. Tokyo: Haniwa shobō, 1963.

Seki, Keigo. Nihon mukashibanashi taisei, vol. 6. Tokyo: Kadokawa Shoten, 1978.

Seki, Keigo (trans.). Adams, Robert J. Folktales of Japan. Chicago: University of Chicago Press, 1963.

Shōnensha et al. Kojiki no hon. Tokyo: Gakushū kenkyūsha, 2006.

Suga, Teruo. The Man'yo-shu: A complete English translation in 5-7 rhythm. Tokyo: Chūkyo Shuppan, 1991.

Suzuki, Norio. Toshiyori zuinō no kenkyū. Kyoto: Shibunkaku Shuppan, 2006

Takagi, Yūko. Nihongo no moji, hyōki nyūmon, kaisetsu to enshū. Tokyo: Babel Press, 1996.

Tokuda, Kazuo. Otogizōshi kenkyū. Tokyo: Miyaishoten, 1988.

Tyler, Royall (selected, edited, and trans.). Japanese tales. New York: Pantheon Books, 1987.

Uegaki, Setsuya, and Hashimoto, Masayuki. Fudoki o manabu hito no tame ni. Kyoto: Sekaishisōsha, 2001.

Ujitani, Tsutomu. Nihonshoki (ge), Zen gendaigoyaku. Tokyo: Kōdansha, 2004. (First published in 1988.)

Ujitani, Tsutomu. Nihonshoki (jō), Zen gendaigoyaku. Tokyo: Kōdansha, 2004. (First published in 1988.)

Yamanaka, Yutaka. Heian Jidai no Rekishi to Bungaku, Bungaku hen. Tokyo: Yoshikawa Kōbunkan, 1981.

Yamanaka, Yutaka. Heian Jidai no Rekishi to Bungaku, Rekishi hen. Tokyo: Yoshikawa Kōbunkan, 1981. 
Yasuda, Motohisa. Nihon zenshi 4 Chūsei I. Tokyo: Tōkyō Daigaku Shuppankai, 1970. 